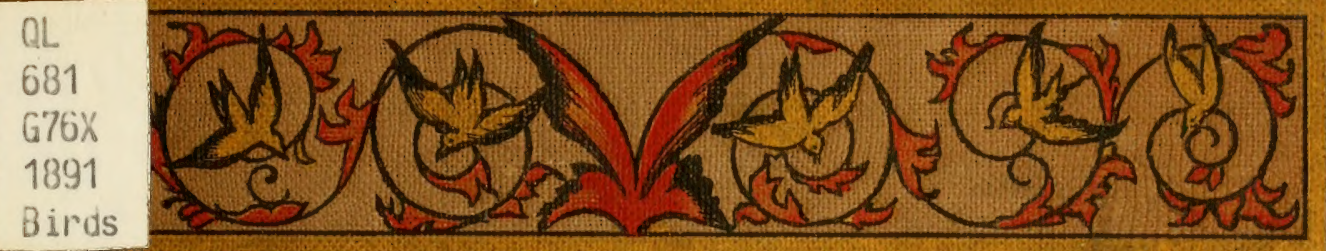

OUR (ONMON BIROS AND HLW TO KNOW THEEM By JOHN B. Grant

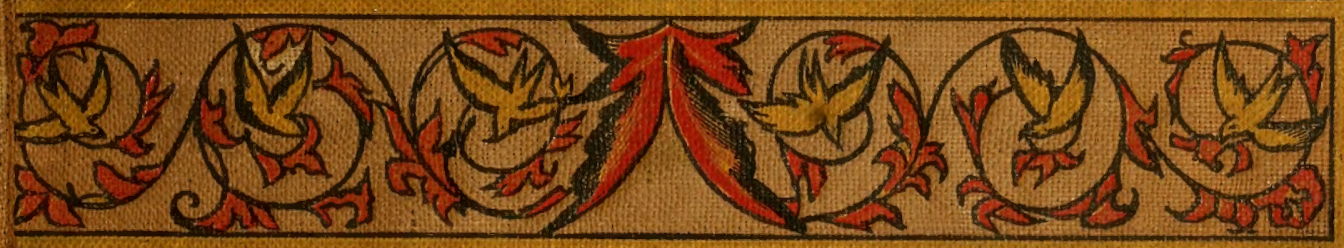


An 
s Birds

\title{
OUR COMMON BIRDS AND HOW TO KNOW THEM
}

\author{
B) \\ JOHN B. GRANT
}

WITH SIXTY-FOUR PLATES

THIRD IDITON
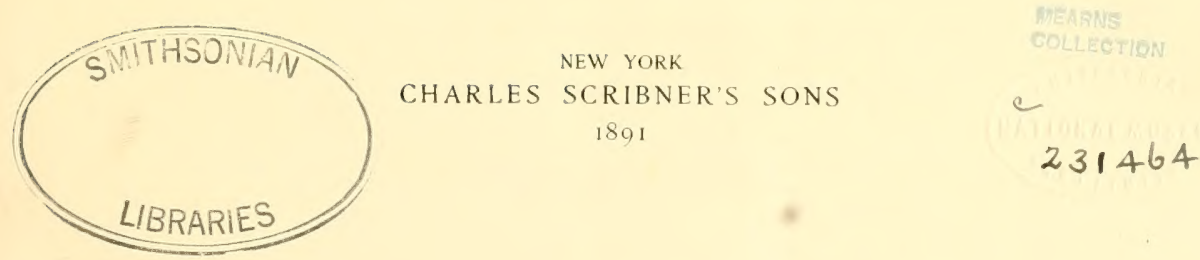
Copyright, IS91, BY

CHARLES SCRIBNER'S SONS

Press of J. J. Little \& Co.

Astor Place, New York 


\section{INTRODUCTION}

IN offering this little book to the public, the author desires to disclaim great scientific knowledge of birds and their ways, his object being not so much to impart information, as to point his readers to the way of acquiring it for themselves. He believes, indeed, that by reason of his own experience, recent and consequently fresh in his memory, he is fitted to make some suggestions, particularly looking toward the economy of time and labor, which will be of value to the beginner in the art of observing birds. He thinks also that, in view of such measure of proficiency as has been attained by him, he can give encouragement by the promise of ultimate success, thus affording cheer to the student, and it may be preventing the abandonment of a study, which, if persevered in, cannot fail to increase the substantial enjoyment of all out-of-door life.

Doubtless, the beginner who has no friend learned in Natural History to counsel him, but is dependent wholly upon the books for guidance and his own untrained observation for facts, will experience certain discouragements. It will seem to him that if he reads up on any one bird and then sets out to find it, that particular variety will be the one which by no chance will he be able to meet with on his immediate excursions ; 


\section{Introduction}

while other kinds, unknown to him, will swarm about him. And, if he reverses the method, and singles out a specimen from those he does find, noting its markings, song and habits, with the intention of subsequently identifying it in the written descriptions, it will similarly appear to him that either such peculiarities as he has observed appertain equally to several varieties, or, worse still, if the books are to be trusted, they belong to none at all. Hence, whichever way he turns the result is the same-many birds seen but none identified.

This is, indeed, a serious dilemma, sufficiently embarrassing and disheartening; but it is to the student arrived at such a despondent frame of mind that the writer hopes to be of use, both with his advice and by means of the plates herewith presented.

As for the advice, though of the simplest, it is believed that it will prove effective. It will be given in detail in the following pages; but the most important, if the least startling features of it, may be here briefly stated.

Study one bird at a time.

Begin with the commonest, that is, the most abundant and most easily recognized ones; it is the province of this book to point such out. 


\section{Introduction}

Do not attempt, at the commencement, to identify any bird which presents puzzling characteristics, or rather any which does not present some striking mark either of song or plumage to serve as a sign for certain classification.

If these rules are observed, discouragements will be avoided, and progress will be realized more rapid than might at first thought be expected.

Regarding the plates, it may be observed that these not only afford the writer his principal hope of aiding the learner, but they serve as his chief excuse for this little volume. Many books have been written about birds, and by those, too, far more learned upon the subject than the present writer is. Reliable and handsome plates also have been published. But the books have either been of a purely literary character, delightful indeed to read, but conveying no detailed instruction to the beginner, or so voluminous and scientific as to repel him who desires only a naming acquaintance with such birds as he constantly sees. The plates thus far published have been in a form so bulky as to forbid their being carried into the field for use, and so expensive as to prevent many from ever owning them.

The plates presented in this volume are photographs of specimens mounted by an 


\section{Introduction}

expert taxidermist, ${ }^{*}$ which represent the birds in characteristic attitudes, sometimes modified, however, to positions best calculated to display plumage marks. Of course, the absence of color will be regretted. But colored plates are costly, and the object here has been to make an inexpensive book. Photography cannot, as yet, reproduce color, but it may, aided by description, indicate it.

Ninety specimens have been selected and described, all of them males, and all representing varieties so abundant that any person may surely find them if he chooses to seek. Of these birds, sixty-four portraits have been given. The descriptions, it is hoped, will be found to be trustworthy, although there is no pretense in them of exhaustive detail. The aim has been to furnish sufficient data to serve the purpose of identification, while avoiding the danger of confusion. The book has been put into such form as to be conveniently taken into the field for the learner's use, while he is actually regarding the living bird. It is not expected to take the place of a larger Manual, but to be supplementary to such a work. A complete Ornithological Treatise is a desirable possession for the bird-lover from the start, and it will become gradually indispensable to him as he grows in knowledge

*J. Wallace, 16 North William St., New York City. 


\section{Introduction}

and desires fuller and more detilled information than a small volume such as the present one can supply:

The hirds which have come under the athor's own observation, and whose habits are here recotded. Were seen on Lome lsland, near Flushinge and at various points upon the Hudson River between New York City and Peckskill : and in this connection it must he hotne in mind that hirds habits vary greatly in different localities, so that absolute conformity to customs mentioned here most not in ofluer places be invariable expected. Thus, to mention a single example. hids which, in one part of the country, nest upen the ground, may, in another part, be found building in trees.

Until a comporatively recent date, mo universally accepted system of bird momenclature has been in vogule. Naturalists have. perthaps, not always been wise in the names they have bestowed upon the several varieties, and their suciessors have not hesitated to christen agrain and again acordmy to their suppesed better fuderment or knowledere. It therefore came to pass that a hird could have several sichtitic, that is. I.atun names, and it was even necessary in some instances, when making use of one of them. to append the name of the man who had appled it. to indicate with certainty what burd was meant. 


\section{Introduction}

This state of things naturally created considerable confusion-a confusion which must unfortunately continue to exist in all our hird literature antedating in publication the year 1885 .

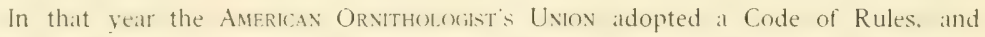
issued a Check List prepared hy a committee appointed by the Society. This document was compiled with so much learning and conservative wisdom, that its authority has heen recounized by most if not all ornithologists and its nomenclature adopted. The arrangement and nomenclature of this List have been followed as a matter of course. in the present look, so far as the Latin names are concerned. In regard to the common names of birds, however, which are in no sense scientific, the author has frequently allowed himself to make use of those which seem to him more familiar. For example, Pine Finch insteid of Pine Siskin. Indigro-bird insteild of Indigo Bunting, Red Crossbill instead of American Crossbill, etc., etc.

Many hooks have been consulted to correct or confirm the author's own statements ; likewise to furmish athority for the descriptions appertaining to a small number of specimens which he has not seen in life, but which, for the sake of completeness, he 


\section{Introduction}

has thought it best to include in his list. Two of these works require special mention, because of the liberal use made of them. They are lr. Elliott Coues' Kry to North

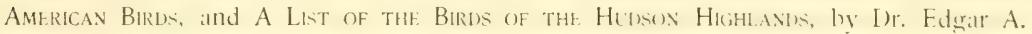
Mearns. The measurements of hirds given in the latter of these works have, with slight modifications, been adopted here. The figures are the average lengths of from half a dozen to about half a hundred specimens, and may serve as a ereneral indication of size. Dr. Mearns' LIsT is the source also from which most of the diates of migration have been taken.

It should also be said that the ideal of a calendar of hird arrivals and departures is not an original one. Dr. Allen published a somewhat similar list of New England birds

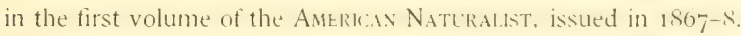

Thanks for assistance are due to Mr. E. A. Farirchild, Principal of the Flushing Institute, and to Mr. Clifford Sinyth, of New York City,

To Dr. J. A. Allen. Curator of the Ornithological l)epartment of the Museum of Nitural History of New York City; the author is particularly indebted for kindly advice and much valuable help in various ways. 

Our Common Birds and How to Know Them 
"Whan shaws beene sheene, and shraddes full fayre, And leaves both large and longe,

It's merrye walkyng in the fayre forrest

'1o heare the small birdes songe.'

- Ballad of Robis hood and Guy of Gisbornt 


\section{OUR COMMON BIRDS AND HOW TO KNOW THEM}

THE equipment necessary for an observer of birds is not large. He needs only a pocket note-book, a good opera or field glass, stout and easy hoots or shoes and clothing of strong texture and inconspicuous color: these for the field. For the study he must have a good book of reference (there is none better than A KEY TO THE. BIRIS of NORTH Amerka, by Dr. Elliott Coues), and a journal. The notes made during a ramble will, of course, be hasty. incomplete, in short mere memoranda; but the transcriptions of these into the journal should be elaborated with care, and in the best literary style possible. This journal will be frequently read. hoth by its writer and probably by his friends. and it may with great likelihood form the basis of future publication. Morcover. it should be written out as soon as possible after the excursion whose results are to be recorded. and while the observations regarding markings and halbits of specimens remain clear in the memory ; for, if this be not systematically done, and if the notes of several days ramblings be allowed to accumulate, it is more than likely that there will be a confusion of the facts beyond the power of the field book to disentangle. 


\section{Our Common Birds and How to Know Them}

But if the would-be observer looks forward to what maly be called professional work, and intends to make an exhaustive study of ornithology, he must kill birds and learn to skin and preserve them: and for this purpose he must have a gun and a set of taxidermist's instruments. [)r. Coues, in his kis. grives full directions regarding the use of these. together with ample instruction in the formation and care of a collection. In the present little work this branch of the subject will not be discussed. and only such familiarity with hirds will be sought for as may be attanned by observation alone and through the instrumentality of no weapon more deadly than the opera-glass.

Armed, therefore, with operatglass and note-book, start out in the early morning or towards sunset. It is at these times during the summer season. that hirds are altive. In the heat of the day no observations can le made of sulficient importance to repay the personal discomfort and even risk which exercise at such a time involves. The few hours immediately succeding day-break are best of all, but for obvious reasons a somewhat later period will be chosen by most people. and indeed there is enough occurring for quite a large portion of the mornings to repay the watcher. After all, the occupation 


\section{Our Common Birds and How to Know Them}

is undertaken for recreation. and let him to whom early rising is an abomination, in the name of Morpheus, slumber on ; only, when his tardy start is effected, he shatl not witness bird-life so exuberant, nor listen to such floods of melody. nor inhate such richness of perfume, nor lind refieshment in airs so balmy, as he misht bave done had he been earlier astir.

In Spring and Fall, however, the conditions ate somewhat different, and mid-daly walks may well be productive of good: while in Winter they alle sometmes best of all.

When exploriag open country, such as tield and meadow, walk briskly. Here you cannot hope to steal up to your hird and study him. yourself mobserved. The most you can do is to come upon him suddenly, mark the spot whence he starts that his nest may be searched for ; note his manner of flight, getting at the same time such details of plumage as may be possible, and perhaps stalk hum in the tree or thicket where he has taken refuge. And this stalking must be deftly done. Approathes must be accomplished by detours, with advantage taken of trees, bushes, rocks and mounds for partial concealment. Nor may you push your investigations ton fir : a bird's quickness of sight and hearing is remarkable. and its dislike of inspection a universal 


\section{Our Common Birds and How to Know Them}

trait. It is also surprisingly clever in discriminating between the casual wayfarer who is oblivious of its presence, and him who comes to spy upon its privacy.

Therefore, your hunting must he full of Indian-like craft and subtlety, and vour standpoint for observing chosen with good judgment. But. should it happen. as too often it will, that the hird you atre following is unusually shy, and you ferel doubtful of heing able to attain a sufficiently near position. artifice may still enahle you to carry out your design. Throw off now all appearance of stealth or watchfulness, and, assuming the gruileless and unconcerned manner of the purposeless loiterer. stroll along. not too directly towards the bird, and particularly avoid any steadiast gazing. Duplicity of this sort will frequently outmatch your adversary's salgacity, and should be practiced in its proper time.

Another expedient for retarding a bird's too hasty departure. sometimes adopted with success, is to give utterance to sundry chirps and whistles to which you will endeavor to impart some resemblance to bird-language. It is a fact. unlikely as it maty seem, that a lird will often remain to answer, and will sometimes e'ven approach quite near to the accomplished mimic. 


\section{Our Common Birds and How to Know Them}

When wandering in woods or erroves, tactics of another sort should grovern vour proceedings. Here you mily confidently expect to surprise mang a herd, and therelore you shouk go slowly. With vour attention grven mostly (1) the tree-tops. quick to notse and investigate each motion among the lranchess and with ears alert lor covery chipp or twitter. In such a place voll wall, perhaps hear the chatter and see the hright eves

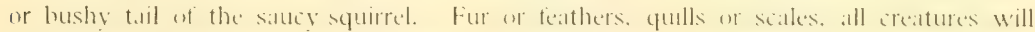

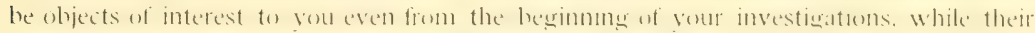
importance will intensify as increase of knowledge is ohtained.

When you have come upon a burd, of contse vour operaterlass wall be put to use. But even in rasing it to your eyes gener movement should be dediberate. Never forget that a hasty motion or the equick ghancing of the sun upon the hatrel of lens of the glass is sufficient to betray vour presence. Now that vou are watchang vour specimente it might. perhaps, seem that your end is attained and that no further specul quallications are needfial for what remains to be done, the simple alt of alservation. Not st): your observing ficultics must he tranted hefore grood results can he assured. It is not sufficient that you see in a merely superticial way : you must he capalye of detectines special and 


\section{Our Common Birds and How to Know Them}

distinctive pecularities, and the ability to do this comes to few except through training. The bird's markings should be carefully studied; the tail and wings should he noted, whether they le long or short. slender or full, and whether the former be rounded. square or notched: the tints of hill and legs should he remarked; attention should be given to characteristic hahits. such as the flight. Whether straight or undulatory : the position maintained in the trex, whether high or low in the branches : the greneral deportment, whether restless or composed; the nature of the environment. whether marsh, meadow. wood. upland or lowland: and ahove all. the song or note of the hird should be so thoroughly learned that it will he instantly recosnized when again heard. These and a host of other observations of a kindred nature should he diligently made and faithfully transcribed in vour note-hook. Ther will assist you greatly. not only in determinings the species when you have opportunity te consult your reference hook, but, if you chance already to know the individual, they will strengthen former records of its halnits. not unfecpuently show variations either before not remarked or peculiar to locality, and will alwalys tend to increase vout intimacy with the bird.

D) uring the actual inspection of a specimen, it is usually unadvisable to withdraw 


\section{Our Common Birds and How to Know Them}

one's eves for the purpose of making memoranda since if one loses sient of a bird. it is frecpently difficult to resain it. Betore the next specomen is sought, however. the notes desiriptive of the ene just observed shoukd halufually he made. and that tore. be it remembered, with the thoroughness which has already been stremuously advesed. Depend upon it, the mme and trouble bestowed upon these notes wall he certainly and speedily rewarded.

A third. and for an indolent mature an extremely pleasant. method of studving buds is to seek some spot which possesses peculialy attrative teatures for them, and whither they are accustomed to resort in sreat numbers. and there. properly sheltered. seat vourselt and quitety wat for what may come within the range of vour vision. I hate in mind two localites that have always proved wondertully rich in bird-lite. (one is at bluff, perhaps forty feet in height. rather sterep. and with a number of gond-sized forest trees growing upon its slope. Rolling tields spread hackwards from its bow, and at its foot rums a line of shrubhery, somewhat thicket-like in character and tormons a sort of natural hedge. which fittingly bounds a bogerg meadow bevond. Sereral small sprongs issue from the sides of this declivity and trickle down 10 wentle streans untel lest in the 


\section{Our Common Birds and How to Know Them}

ditches which intersect the meiduw. Meadowlarks, Blackbirds, Marsh Wrens, Bitterns. Bobolinks and an occasional louk frequent the lowland. In the upland, the cowbird. the Robin and the Soner Sparmw disport themselses: inte the trees and shrubs upon the bluff conte Woulpecters, Thrushes. Orioks. Cithirds. Flycatchers and Warblers. and all of these. and. indered, more than I have named, take turns in visiting the springs and rivulets: now indulging in a hasty bath, now daintly slaking their thirst, now

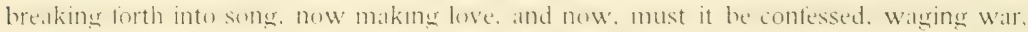
all utterly unconscous of the ohserver. Who. redining upun a mossy hank. or sitting motionless upon a loge of stump. or leaming tixedly against the trunt of some triendly tree, is watching with intense interest the scenes of sylvan lite unwittingly enated before him.

such is one of the firvored spots. The other is an old. deserted and gente-toruin apple orchard. lar from any habitatum. except a few seattering farm-houses. This orchard is skirted on there sides by torest trees, and on the remanning sike by at swamp, which is a tamele of alders and other water-loving eroweths. Here maly he seen the Orihard Oriole. the Black-billed Cuckon, the Indigo-hird, the Summer Redhird, the Towher, the 


\section{Our Common Birds and How to Know Them}

Redstart, the Americin Goldtinch. Wens, Throlsers, Virees, and numbens othel

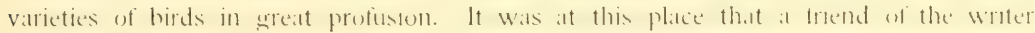

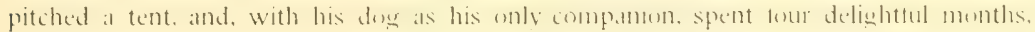

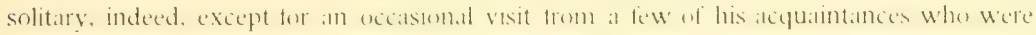

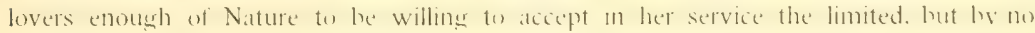
means comfortless, accommodations of a cambas house and a somewhat rudimentary couch. It was the writer's goond fortume to be reckenced among the favored ankes, and the days spent there in delightful rambles and the crenimers passed in luxurtens represe will linger long in the memory.

Here I mate my tirst acpuantance wath the Black-billed Cuckos. It was at dawn,

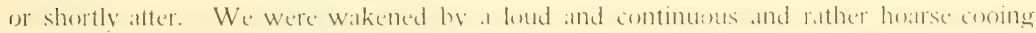

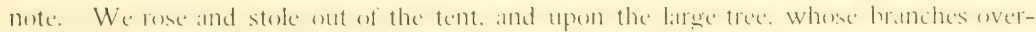

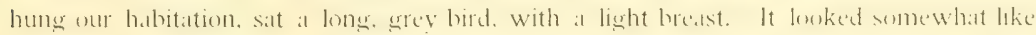
a Pigeon, and. indered. its utterance bore a certain resemblance to the crom al that bird. It was not loner, however, before we knew it to be the Cuckon, and we stond and watched it with interest for many minutes. Alter a time we pefocived several 


\section{Our Common Birds and How to Know Them}

others of its companions noiselessly tlitting among the branches of some adjacent trees, and our first friend finally joined these and all depanted.

1)oubtless. there are specially favored spots in every region, where the olserver will meet with the objects of his search in ureater vartety and profusion than in other places. and to him who once hecomes attentive to ornithological pursuits. they will speedily become well-known and favorite resorts. Mr. Burroughs, a constant observer and at chaming writer. tells of a certain hemleck wood where. during one ramble. he counted "over forty varleties." But it is mot essential that multitudes of hirds should he present to render the occupation af the student attractive. In talet. it is not eertain that too grealt a vallety would mat be a means of comfusing the hegrinner. His attention would possibly he diverted from one specimen to another with such rapidity that he coukd not sufficienty familiare himself with any. Certanly. the closest olservers hate never made it a matter of complaint that objects for study were not at hand. Mr. Bradford Torrev. either from necessity or choice, made the Common in the city of Boston at ficld for his study of hirds. (Ine wenhd sid that this was not a promising site. In fact. Mr. Torrey admits that the place is not an ideal one tos such a purpose. though in justice 


\section{Our Common Birds and How to know Them}

to him. it must be stated that it is not of the scarcity of objects that he complans, but of the publicity of the situation. He sivs: "Other things heing exual. at modest ornithologist would prefer a place where he could stand still and look up without becoming himself a gazingr-stoct." Nevertheless. Mr. Torrey did " stand still and look up." and to good purpose, too. He salys : " Within the last seven ar eight vears I have watthed there some thousinds of specimens. representing not fia from seventy species." That is what it is to have the love of observing and to know how to exercise it. The ordinary citizen of Boston passes through the Common every diy of his lite noticing only English Sparrows, and perhaps a few Rohins. But Mr. Torrey tinds . not lar from seventy spectes."

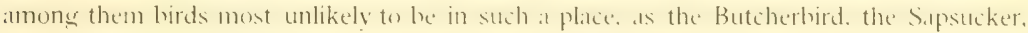
the Maryland Yellow-throat, the Cuckex), the Kingtisher and the ()wl. not to mention at Mockingbird. a Cardinal Grosbeak and a Paroquet. which he sucsses to be escaped cage-birds.

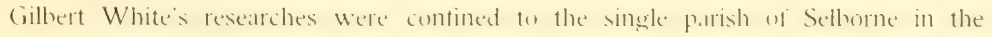
county of Hampshire. England: and his diaries and letters to his friends, . Thomals Pennant, Esquire," and " The Honorable Daines Bartington," in which he discusses and 


\section{Our Common Birds and How to Know Them}

comments upon the quadrupeds. birds. insects. woms. vegretables. weather and antiquities of his parish. have been the delight of succededing generations of readers, whether naturalists or simply cultivated people of no especial calling.

"I tind." he writes. " that that district produces the greatest variety which is the most examined:" a sieniticant remark. and. coming from a past-master in his ant. werthy of full credence. We maly, therefore, be assured that whatever place we are in will he found to wlee full scope fire studies in ratural history. All that need concern us is lest we ourselves fall short in requisite diligence.

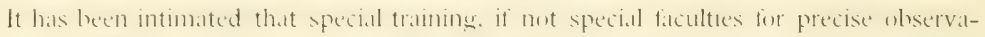
tion are needtul to make one a really send observer. Henry I). Thoreate mes be cited as a type of this sort of student, and though his personal chanater mate repel one by reason of its intense exotism; and though one he constantly excited to resent the scom with which he regarded his fellow-men and which he did not hesitate to express: still his reverent leve of nature must produce sympithy and his untiring conergy in the pursuit of a knowledere of hes secrets must command expect. while the contemplation of his life and work must alwaty he of use to a person engaged in similar resealloh. 


\section{Our Common Birds and How to Know Them}

Thoreatu hat the ficulty of quick and accurate observatton to a most extratordinary degrese. Emerson, in a biographical sketch of him. salys: "He noted what repeatedly betell him. that after receiving from a distance a rare plant. he would presently find the same in his own haunts. And those pieces of lack which happen only to good players happened to him. One das. Walking with a stranger who incuired where Indian anrow-heats enuld be found, he eplied. 'Fverywhere' and. stomping forward. picked one on the instant from the ground. At Mt. Washington, in Tukenman's Ravine. Thoreau had a had fall. and spromed his firot. As he was gretting up from his fall, he saw for the first time the leaves of Arnica mollis."

Read in his joumals how he chronicles the reddeninge of the maple buds. the first

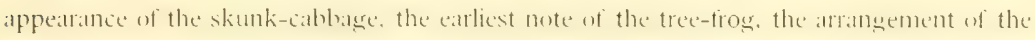
sand upon the rail-road embankments in tiny rideses cansed by showers of ram. Nothing is too trivial to escalpe him. and there is mothing that does not secure the interest of his reader also when once prointed nut and commented upon in his uwn happy manner.

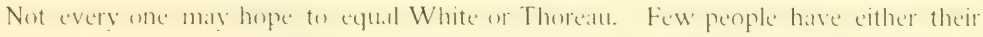
talent or the leisure for its exercise. But there are many. nevertheless, whose love of natture 


\section{Our Common Birds and How to Know Them}

is similar in kind if not in degree to that which dominated them. Some of these, who are now smply conscious of a general. undefined feeling of pleasure when contemplating a charming view, and who, when brought hy chance into contact with a bird or an animal in its native haunts, experience only a momentary merest and admiration at the sight some of these (and more. perhaps. than are themselves atware of any such predilection) alre fitted to share that glorious thrill and glow which nature bestows with liberal hand upon her devotees. If they have not alreanty felt that delight it is only hecause they have hitherto slighted her.

Let us suppose a person of this kind : one. susceptible indeed te rur.ll delights. but engrossed in other affiars. and hitherto inattentive to natural incidents or objects. Let us suppose some such incident or object to be thrust upon his sight in a way strongly to attract his notice. Say that upon one of his rambles he finds a birds nest containing a complement of exgss and is struck with the cleverness of the structure and the beatuty of its frigile contents. Can we not perceive that here may be the starting-point from which he will become an acomplished observer? And maty we not ealsily fincy the succeeding steps of his progress? His curiosity is roused, and he takes his station neall hy 


\section{Our Common Birds and How to Know Them}

to awat the coming of the owner of the nest. He is not leng delatved. for he soon discovers that yonder little bird. thitting and chirping in the adjoming thicket with manifest uneasiness must be the one he secks. After some time spent in watchinge he departs, only to come next day and the next. until the exess have given place to foung birds : and now he has attained such dexterity of approtich that he is ahle to come near enough, himself

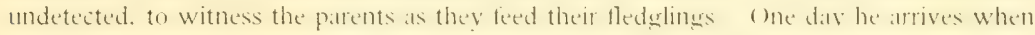
one of more of the youmg birds essily their first tlight. Rut kng hefore this he has found means to intom lomself of the species of the birds he ss studyinge and he is well an the way to hecome a hird ohserver. Indeced it maly he contidently asserted that he hats mot

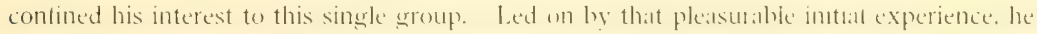
has noticed many wher birds and has to some degree studied them actions fou. He has karned the songes of some kinds, he has seen them feeding he legerins to know in what places to look for certain varieties, and at last he discovers that his aceuantance not only with birds, hut with insects. quadrupeds. plants and trees hats become comsiderables and he is forced to acknowledge that all nature has taken on a new aspect for him. Moreover, his daily enjoyment has enormously increased, in that his resources have beer multiplied 


\section{Our Common Birds and How to Know Them}

and his capreity to comprehend has heen enlanged. while his health, hy reason of abundant out-of-door exercies, and in comseguence of the relaxation which commes from a diversitv of agreeable pursuits, has received great benefit.

It has been thus with mang who have been led on hy insensible degrees. until they have attained considerable proticiency in natural lore: and so it will derabtless be with many more : and while it is not to he expected that every one who desires an intelligent understanding of the subject will aim te hecome a leamed scientist, still it is desirable that evers one should stant in the right direction and then the point (o) which he will arrive maly be safely left to the determinaten of the many circumstances and anditions which govern the conduct of each individual.

fonceming that branch of natural historv termed ()mithologe which we are here briefly consideringe. three methods of procedure have been indicited and andvice has leen griven conceming eath. In the limt 1 wo. the student walks through woods and forests. and in open fields and meadews. In the last he is seated at ealse in some favorable spot

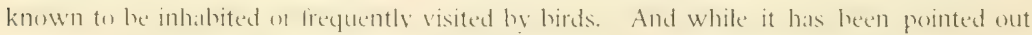
that each of these methods recpures different treatment, it has heen assumed that all of them 


\section{(Our Common Birds and How to Know Them}

will he practised. since they are all not only dependent upon earch other. but are alse equally valualue in their results and delesheful in their prosecution. The discussion has

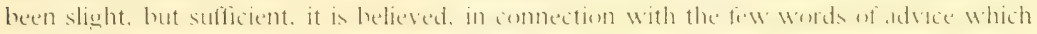
follow to start the novice upon the right way.

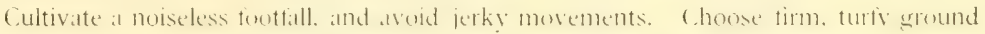

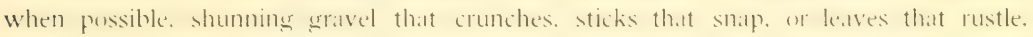

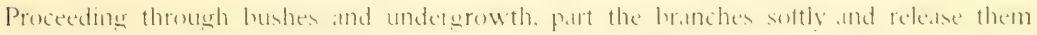

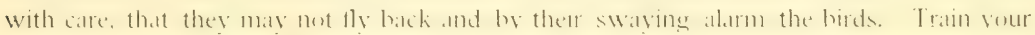

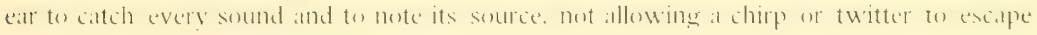
you ar to remsin unexplaned. Accustom wour eye to mak avery movement. teaching it to discriminate betwixt the wind-stimed leal and that set in motion ly hird or sequirel. All tirs. with pratice. Woll become more and more eas until it will le decomplished

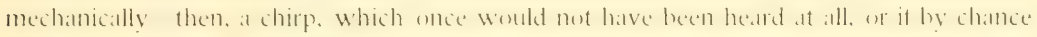

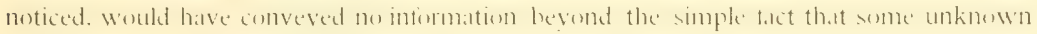

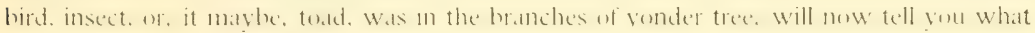
the creature is and allure you to investigations of delightful interist. 


\section{Our Common Birds and How to Know Them}

But be patient. Do not expect to kean immediately all there is to be known. And

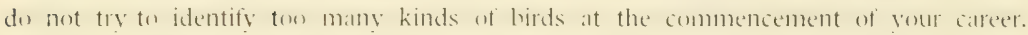
Chouse for your tarlier studies those that are at the same time abundant and that ane striking in plumage or songe or both : combining yourselt to male birds that is to salv, to precisely those which alone as a rule possess these well-matked characteristics. For if you puzzle over eath bird you see. and with all your pains fail to become satisfied as to its identity. you must he a person of uncommon persererances if you do not soon grow disheartened.

You now probatidy know the Robin and the crow. Who does not? Well, begin with these. Study them. Thes alones if really studied, are capable of allordinger much entertainment. As for the Robin vou need not leave the precincts of vour own garden to find him. But there are other hirds probalsy not known to gou, and yet always present in great mumbers, which you may immediately add to vour list for present study : confident that after reading alout them in the books vou will recognas them on sight : or even should vou chance to meet them without preparation that vou will be able to identify them hy subsequent reference to the looks. They are the Red-winged Black- 


\section{Our Common Birds and How to Know Them}

bird, the Catbird, the Thrush fat first you will not be able to sily which one of the Thrushes). the American Goldinch, the Baltmere Oriole, the Cuckere. the Flicker, the Hummingbird. the Indigo-bird, the Bobolink, the Meadowlank, the Scallet Tanatger, the Bluebird. the Summer Redbirt. the Blue Jay. the Chickadere the Kingtisher, the Chimney Switt the Barn Swallow. the owl and Wondpecker (perhaps the particular kind ot these last two will puzzle you), the House Wren, the Cedarbird, and. alter you have learned the song, the Song Sparrow.

This is no mean catalogue, and. when you have become fimiliar with the burds comprising it. you will feet that you have added to the mumber of your acquantances a very goodly company. But betore this is accomplished. and it will mot reguire al long time to do it, you will have unconscionsly kanned to know mamy less easify distinguished birds among the Flycitchers and Warbless, not to mention some of the more soberly attired partners of those birds which have lexen mentioned.

In selecting such a list as has been given however, it must be horne in mind that some of these birds vary in coler according to the time of vear. The Bobolink, for example, in Spring and Summer is strongyly marked with white. black and butr. while in 


\section{Our Common Birds and How to Know Them}

the Fill he becomes streaked with different shades of brown. The American Goldfinch in Summer is bright yellow with a blakt crown : in the Fall the black on his head disippeats and the yellow of his boxly bates to a pale bown. And the lndigo-bird does not attain to his full brilliancy of plumage until he has heen with us some time. The books, hewever. will apprise you of such elamges and no serious trouble on this score need he apprehernded.

P'repare for veraself. therefore a list somewhat similat to that which has here been

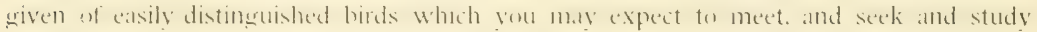

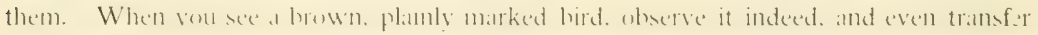

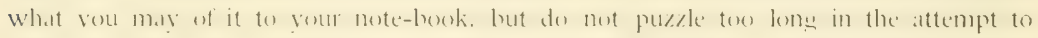

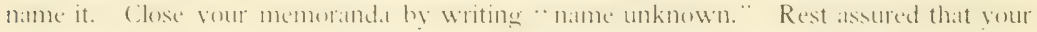
knowhedge will surely angment. and such entries will ocour less and less frepuently. It is interesting and oltentimes helpful ter consult colored plates. But ow wing to the great expense of really gond ones. not everyhody can do this. An extremely erond plan is to make an ociasional visit to the institutions where stulfed specimens are kept, such as the various museums of natural history. Here it maty easily hapen that a glance will set at rest doubts thit a long period of field or book study will tail to solve. 


\section{Our Common Birds and How to Know Them}

The suburbin dweller. who is able to continue his observations through every month of the years, will have the privelese of watthing the coming and going of the bisds in their migrations, and, knowing the pertods of theses, will he enabled to inspect each species as it arrives. forewamed, so to speak, of the name of the particulat hird he may expect to see. The grent advantage that an ubserver se circumstanced will possess over him whose country life is limited to a lew months of the Summer. when the birds afe present in bewildering contusion, is olovious. The colebrated scientist, John Tyndall. when illustrating in a lecture on Sound the value of previous information concerning what was to be expected from an experiment. relates an incident in his ancluantance with Faraday. He salys : "I had everything arranged, whers, just before I excited the magnet, he laid his hand upon my arm and asked, "What am I to hok for?"' And then he adds that even " that prince of experimenters felt the advantage of having his attention directed to the special point in yuestion." Just so it is with the student of birds. When told that the Song Sparrom arrives carly in March : that it is streaked above with real and brown; that it has a chestnut crown : and that its sones is " one high note thrice repeated and then a canary-like cidenzal:" and when early m March he hears such a song, and, 


\section{Our Common Birds and How to Know Them}

detecting the singer, remarks that its appearance corresponds with the above description. he entertains no manner of dould that it is the Song Sparrow which he is regarding.

Asain : he is told that the Bluebird comes also early in March : that the upper part of its body is blue. its breast reddish, its belly whitish : and its song is " a soft. pleasing wirlste, uttered both when tlving and when at rest." When at such time he meets such a bird. there can be no rom for mistake in its identitication.

The opportunity for watching the coming and going of the birds is indeed most advantageous for the student. and a calcudar of their arrivals and departures is here appended.

buring the montiss of lanuary and February the following birds are ustally to be found. though few of them are numerous. While in severe winters the greater part will probably be driven southward: White-throated Sparrows. Chickidees, White-bellied Nuthatches, Winter Wrens, Cedarhirds, Shrikes, Golden-crowned Kinglets, Horned Larks, Pine, and Purple Finches, Junios. Snow Buntings, Crows. Blue Jays, Kingtishers, Red Crosshills, American Coldtinches. Meadowlinks. Hoot ()wls. Sireech Owls, Snowy Owls. Saw-whet Owls, Hairy. and lowny Woodpeckers, Flickers, Rolvins and Bluebirds. 


\section{Our Common Birds and How to Know Them}

March

1 to 10 Rohins. Bluchirds and Soner Sprorows come in small mumbers.

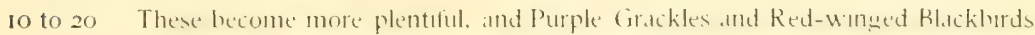
appear. Purple Finches and Flickers recive acessions, and lox Sparrows maly be seen on their northward migration.

Snowy Owls retire nortbuard.

20 to 31 All these become still more numerous. Meadowlatks are recruited, and Phobes and Vesper Sparrows begin to come.

Pme Fincles, Horned Larks, Snow Buntings and Shrikes go north.

April

I to ro kingtishers are recrunted. Red-headed Woodpectiess pass. Myrtlebirds and

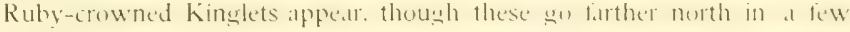
weeks. Yellow-bellied Sipsucters. Cowbirds and Hermit Thrushes arrive. 


\section{On Common Birds and How to know Them}

April

$10 t(1) 20$

2010 ;01

I to 10

\section{May}

Palm Wimblers pass. Field Sparrows and chuppung Sparrows come.

Red Crossbills leave for the nortb.

Whate-throated Sparrows. Chewinks, Chmmey Swits, Rrown Thrashers and House Wrens appear.

Winter W rens ao north. Most of the Fox Sparroa's hate falssed.
Wilson Thrushes. Wind Thrushes, Bluc Yellow-batied Warblers. Yelkw Warblers. Black-throited Blue Wirblers. Black and White Warhlers, Chestmut-sided Warblers, Solitars V'iress. White-eved Virens, Yellow-

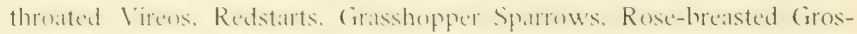
leaks. Baltmore (bioles, and Yellow-healsted Chats arrive.

Juncos and Golden-iroundet Kinglets „s) north. Ruly-irounded Kinglets also resume their nortbward flight. 


\section{Our Common Birds and How tor Know Them}

Mily

10 to 20. Marmolia Warblers. Bar-breasted Warblers, and Blikkbumian Warblers maly be seen on their northem migrations. Boholinks. Orchard ()rieles. Redeved Vireos, W'ood Pewees. Scarlet Tanalgers, Maryland Yellow-throats. Black-throated Green Warblers. Wurm-eatme Warblers. Hooded Warblers. Cuckoos. Indigo-lurds, Great crested Flyeatchers. Least Flycatchers and Hummingbirds come.

White-tiroated Sparrou's leave for the north. Hermit Thruslit's be'come le'ss common, most of the'se also retiring northaard. Murtlebirds also resume their nortbward journey

20 to 31. Black-poll Warblers and Yellow-hellied Flycatchers pass. goiner north. Marsh Wrens appear, and onte may hope for an occasional sight of a Cardinal Grosbeak.

Durne June, July and August the birds effect little change of locality, as nests have been constructed and the duties of incubation assumed. In many cases young hirds have 


\section{Our Common Birds and How to Know Them}

entered into existence and by theil immature and changing plumage have added to the dificulties which the unacostomed observer has already had in identifving specinems. Indeed. unless the student has hy this time made considerable progress in his adequaintance with birds. he will now experience that embarrassment which arises from a superabundance of material. and wall find the number of hirds present bewildering to classify both beciluse of the erreat variety and because of the dissmimaty of the mate female and young of each species.

let him. however. not despat : much mas still he donc he ohservation. and even from the order of their retirement specinems mas be identitied.

Sept.

I to is Milson's Thrushes, Yellow-breasted Chats. Yellow Warblers. Hooded Warblers. Barn Swallows. Bank Swallows. Baltimore (Orioles. Kinghirds. Whiphenerwills, and Hummingbirds now go south.

Blackburmian Harblers. Magnolia Harblers and Yellow-bellied Flucatilers pass on their soutbern migration. 


\section{Our Common Birds and How to Know Them}

Sept.

15 to 30 Wood Thrushes, Chimney Switts, Yellow-throated Vuens. Redstarts. Minod

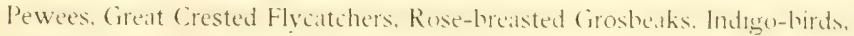
Orchand Orioles. Worm-eating Warblers. Chestmut-sided W.ablers. Cuckous and Boboinks follow.

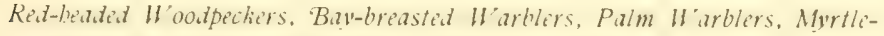
birds and Ruby-crowned Kinglets firss, going south.

Juncos arrive from the north.

Oct.

I to is Hermit Thrushes, Cinsshopper Sparows. Marnh Wrens. House Wrens, Cathirds, Brown Thrashers, Red-exed V'ireos, Solitary Vireos, Whate-eved Vireos. Cowhirds, Scarlet Tamagers. Black and White Warhlers. Blue Yellow-bicked Warblers. Black-throated Blue Warblers and Learst Flycatchers go.

White-throated Sparroüs pass. Golden-irownd kinglets. Hormed Larks, Pine Fincbes and Winter Wrens appear. 


\section{Our Common Birds and How to Know Them}

Oct.

15 to 3 I Oven-birds. Maryland Yellow-throats, Song Sparrows. Chppong Sparrows, Field Sparrows. Pholes. Chewinks and Black-throated Cireen Warblets go : so do the most of the Flickets. Puple Finches, and Yellow-bellied Sapsuckers. Nov. Fox Sparrow's and Black-poll Warblers now wisit as as they go sonth.

I to is l'urple Grackles. lesper Sparrows, and Red-winged Blakkhirds now go, also most of the Meadowlatks. Robins and Bluebirds : leaving us our Winterresident birds.

Snow Buntings and Sbrikes arrive.

Just what prominence to give to the puncly scientific phase of ( ) mithology in a bouk of the lomited scope and modest pretensions of this ome is mot cast to determine. But that some attention should be bestowed upon this branch of the subject, sems advisible for several teasons. fontmual reterence is made an bird literature to family species and genus, and a cleall conception of just what these tems mean is essential to the reader. Agrain, even though a knowledere of the common names only of hirds les all that is at first intended, the time will shorty arrive when the Latin name will be applied, and when this is done, the genus, the species, and sometimes the sub-species, is indicated by the simple 


\section{Our Common Birds and How to Know Them}

use of the name. The Lation name of the Hermit Thrush is Turalus andalaschar pallasii:

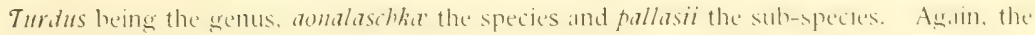
Lation name of the Wood Thrush of Turdus mustelinus. Here Turims is the gremus, and

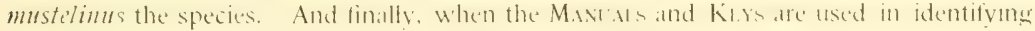
specimens, some limilsarity with scientitic terms and nomenclature is alsolutely needful for an intelligent perusal of the volumes.

It is thought theretere that these comsiderations justili the insertion of a lew rematks of a somewhat scientific character.

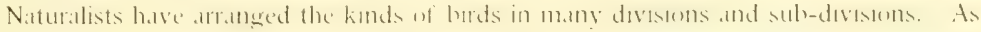

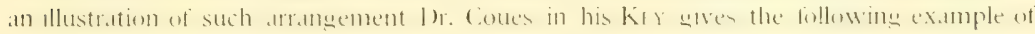
the classification of one hird, manely, Alice's Thrush :

Kingdom, Animalia: Animals.

Branch, Fertedmat: Back-boned Animals.

Province, Souropsida: Lizzard-like Vertebrates.

Class, Aves: Birds.

Suli-cluss, Cimnatu: Burds with keeled Breat-lume

Order, Passeres: Perching Birds.

Sub-order, Oscines: Singing Birds.
Family, Turdite: Thrush-Jıke Birds Sub-family, Turdine: True Thrushes. Genus, Turdus: Typical Thrushes. Sub-genus, Hylocichla: Wood Thrushes.

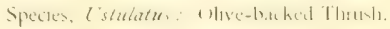
Sub-species, Alicie: Alice's Thrush. 


\section{Our Common Birds and How to know Them}

A scale of sixteen steps is recommended in the Culn of the American Ornithologist's Union as being . "adequate to all practical requirements of even a refined system of classification."

It is as follows :
1 Kingdom.
= Super-order.
? Family.
13 Species.
2. Sub-kingdom.
o Order.
10 Sub-family.
if Sub-species.
; Class.
; Sub-order.
it Genus.
15 Variety.
4 Sub-class.
s Super-family.
12 Sub-genus.
10 Individual.

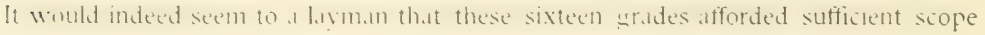
for the classification of any ordinary bird.

All birds, whether living on extenct. betong to the Chass Aies. In this class thete are five sub-classes, viz. :
Sisto 4.
ODONTOTORM.E.
K:III .
Carinat.e.

1)... 


\section{Our Common Birds and How to Kinm Them}

The last two are the unle anes of which there ale living spemmens and it is anly con-

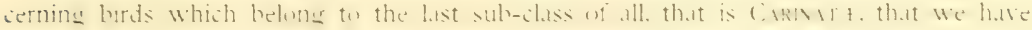
here to deal.

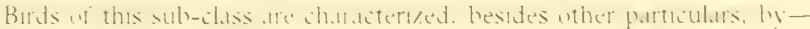
The keeled breast-hone.

A special adaptation to flight, and

The absence of teeth.

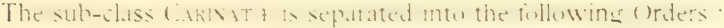

1 Pygopoles: Diving Brids.

z Longipennes: Long-winged Swinmers.

; Tubinares: Tube-nosed Swimmers.

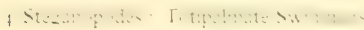

= Anseres: Lamellirostral Swimmers.

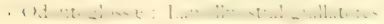

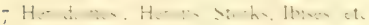

s Paludicole: : Cranes, Rails. etc.

o Limicolx: Shore Birds.
10 Galline: Gallinaceous Birds.

is Columbue: Pigeons.

12 Raptores: Birds of Pley.

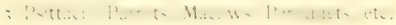

14 Coccyges: Cuchoos, etc.

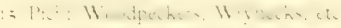

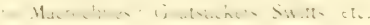

1- Passeres: Perching Birds 


\section{Our Common Birds and How to Know Them}

And into the following sub-orders:

1 Podicipedes: Grebes.

- Cepphi : Loons and Auks.

; Ibides: Spoonbills and Ibises.

$\neq$ Ciconire: Storks, etc.

= Herodii : Herons, Egrets, Bitterns, etc.

1. Grites : Cranes.

; Ralli : Rails, Gallinules, Coots, etc.

>Phasiani : Pheasants, Grouse, Partridges, Quails, etc.

"Penelopes: Curassows and Guans.

in Sacorhanphli : American Vulures.
11 Falcones: Vultures, Falcons, Hawks, Buzzards, Eagles, Kites, Harriers, etc.

12 Striges: Owls.

13 Cuculi : Cuckoos, etc.

14 Trogones: Trogons.

is Alcyones: Kingfishers.

10 Caprinulgi: Goatsuckers, etc.

17 Cypseli : Switt

is Trochili : Hummingbirds,

19 Clamatores: Songless Perching Birds. 20 Oscines: Song Birds.

And these. again. into sixty-six tamilies and torts-six sulp-tamilies, and info genera. species and varieties to a bewildering extent.

There are ahout one thousand kinds mentioned in the CHuk List of the American Ornithologist's Union, some of which are not properly North American Birds ; and 1)r. Coues in his Key describes nearly nine hundred varieties, including birds like the Skylark, 


\section{Our Common Birds and How to Know Them}

which, he savs, "occurs as a strigerler from Europe in Geenland, and also, it is sade, in Bermuda and Alaska," -and the Great Auk, of which he writes, "It seems very im-

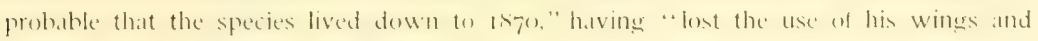
perished off the face of the earth in consequence."

It is not likely that the unprofesisional observer will meet with onc-equarter of this number. Indeed. three hundred kinds would be a great many to be oberved he the most enthusiastic and diligent professional omithologist in any one locality.

The birds forming the little collection described an this hook. are embraced under five of the Orders, viz. :

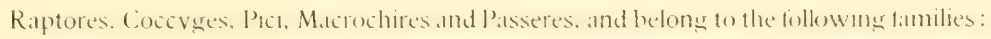

\begin{tabular}{|c|c|c|c|}
\hline Buhonidæ. & Trochilidie. & Tanagridie. & Mniotiltidx. \\
\hline Cuculidie. & Tyrannide. & Hirundinide & Troglodytidx. \\
\hline Alcedinidx. & Alaudide. & Ampelid.e. & Paricle. \\
\hline l'icidze. & Corvidu. & Laniidxe. & Sylviide, and \\
\hline Caprimulgidx. & literidx. & Vireonid.e. & Turdille. \\
\hline
\end{tabular}

They are representatives of eleven sub-famulies and number ninety individuals. 


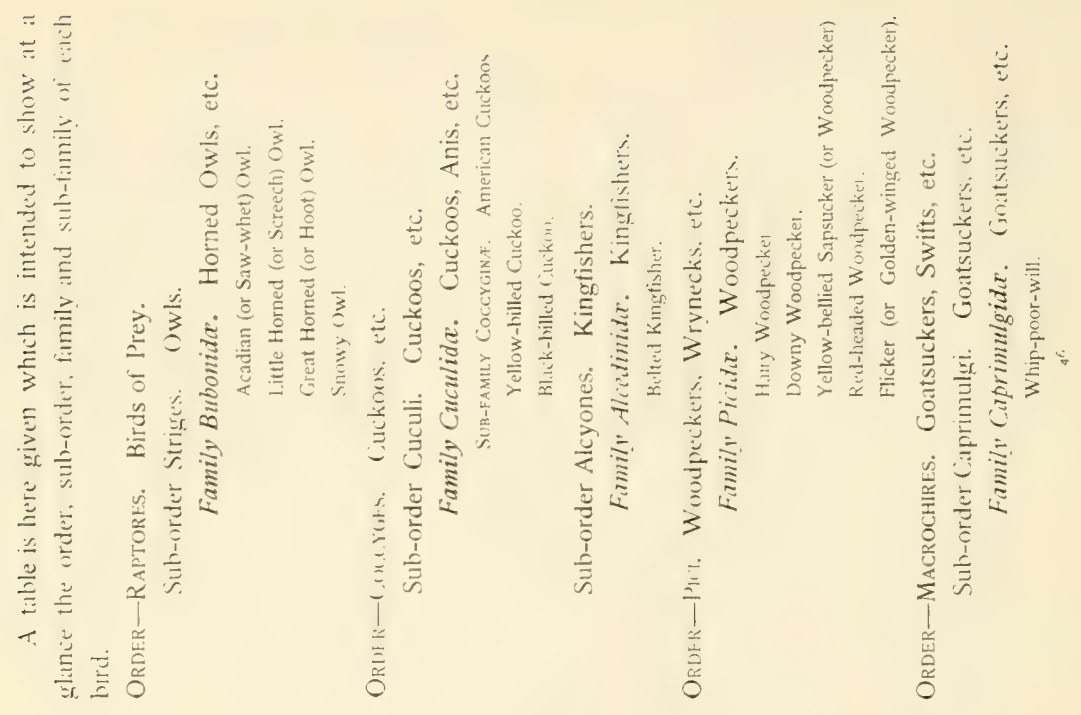




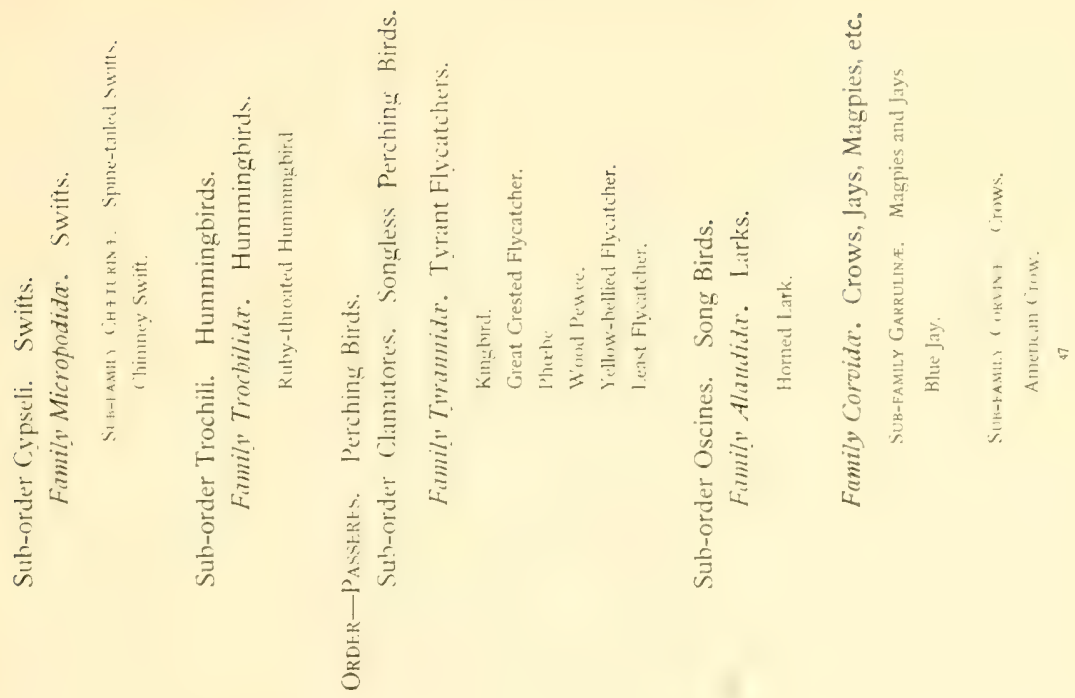




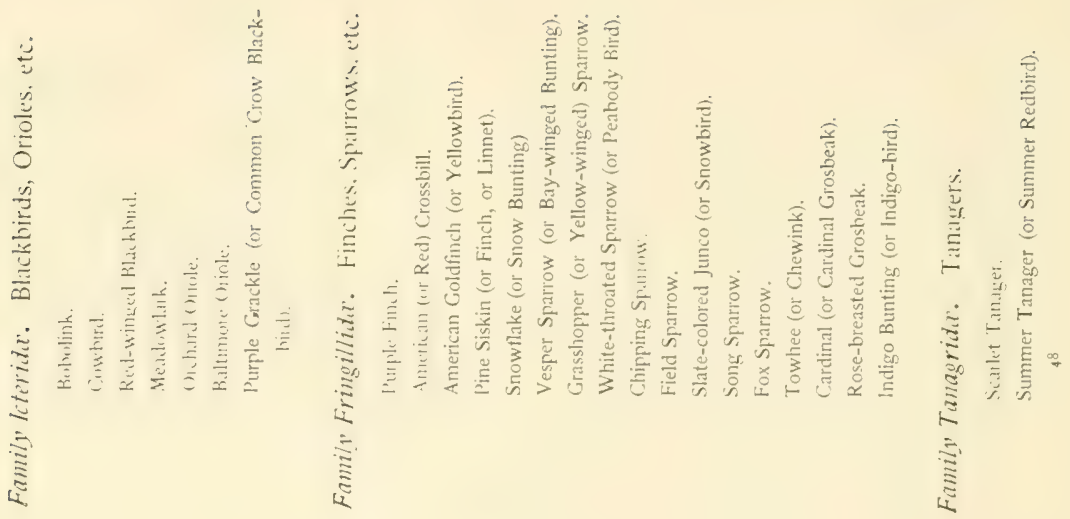




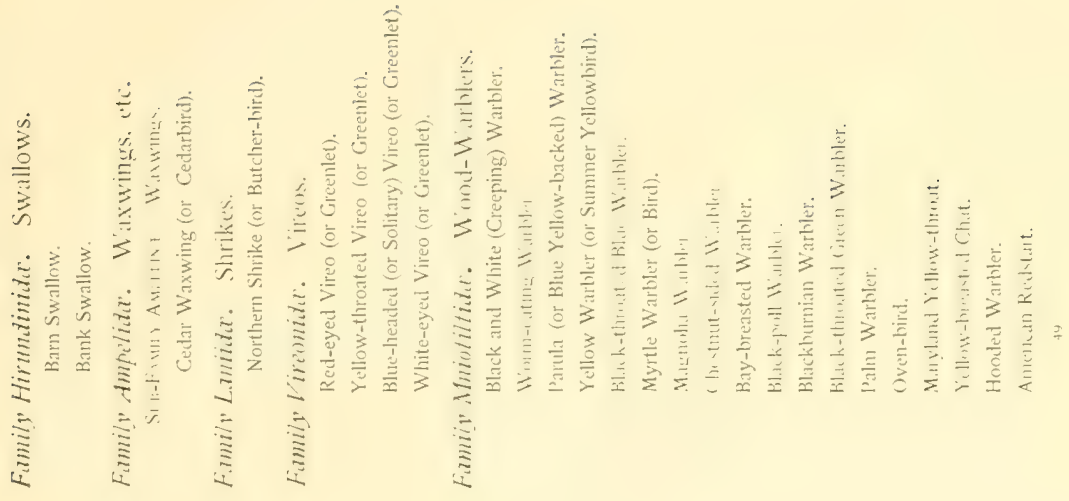




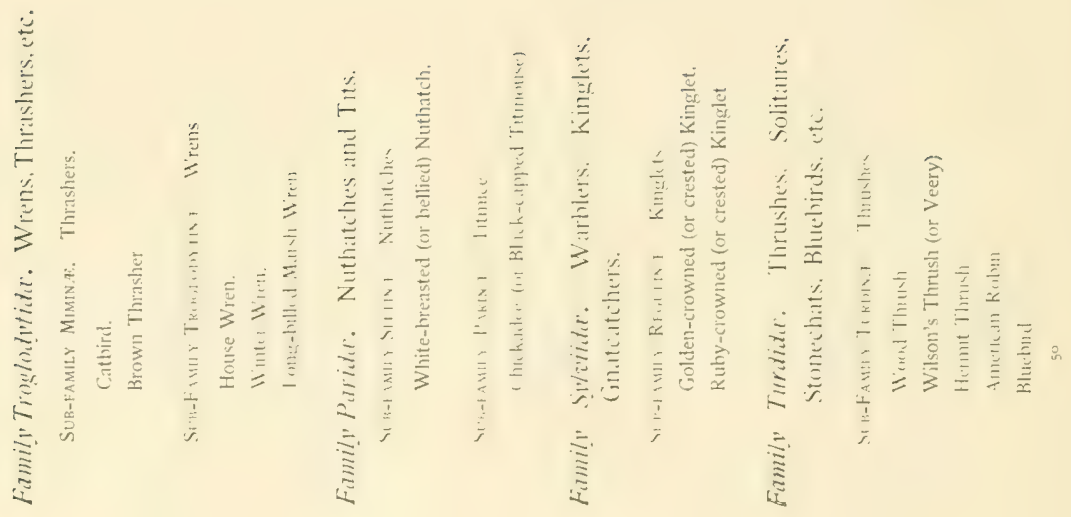




\section{Our Common Birds and How to Know Them}

The largest famly of North American birds is the Fringillider, and comprises Finches. Buntings. Sparrows, Linnets. Crossbills, Grosheaks, ete. The observer will meet numbers of these and will doubtless at first find it difficult to identify many of them. The next largest family that he will have to examine is the Monotiltida or Word-warblers, a family perhaps stell more diticult of identification. since they are mostly small. shy birds. impatient of close inspectom and sonersters of small ahility. Ir. Couses calculates that these two fimilies constitute about one-fourth of the spectes inhathitmg any one mland locility. Flycitchers and V'iress are also usually ahundant and are likewise not the casiest of birds to identify. But, with lew exceptions. and refermeng alwats to the males only the hirds of the remaining fomnlies an lee exsly learned. They present such notable features of plumage song or hahits that they need only to be seen or heard to make identification certain. 



\title{
PLATES
}

\author{
AND
}

DESCRIPTIVE TEXT 


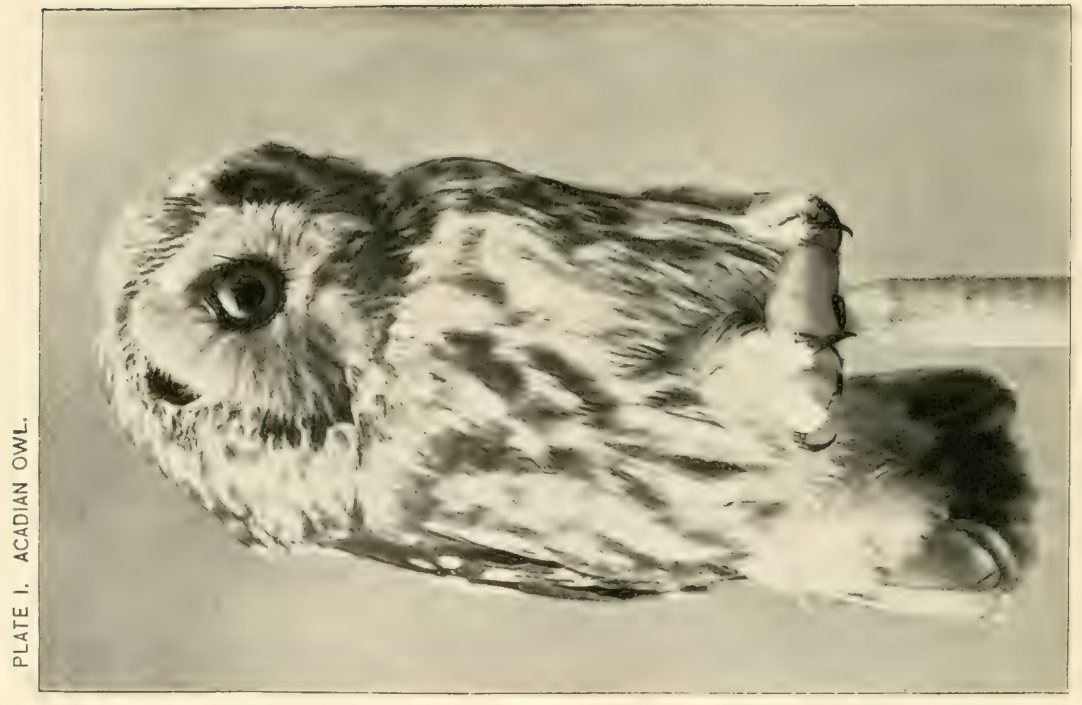




\section{PLATE I. -ACADIAN OWL. SAW-WHET OWL.}

\section{Nyctala acadica.}

Above reddish-brown spotted with white: bentall gratish-white splashed with brown: much white on throat and neck: tail somewhat barred: iris yellow : bill and claws, dark. Lemgth, s inches.

Resident. The smallest of our owls, and, though trom its shyness mot trequently seen. not an uncommon bird. It nests in hollow trees on stumps. or in holes in rocks. Audubon salys: " The sumed of its lowe-notes hears a enteat resemblance to the noise produced by filmes the teeth of a larese silw." It is this smilarity which has ganed the bird its common name Saw-whet.

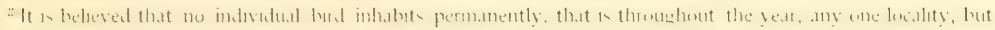

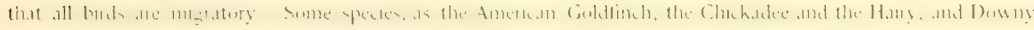

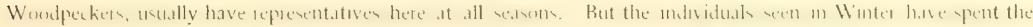




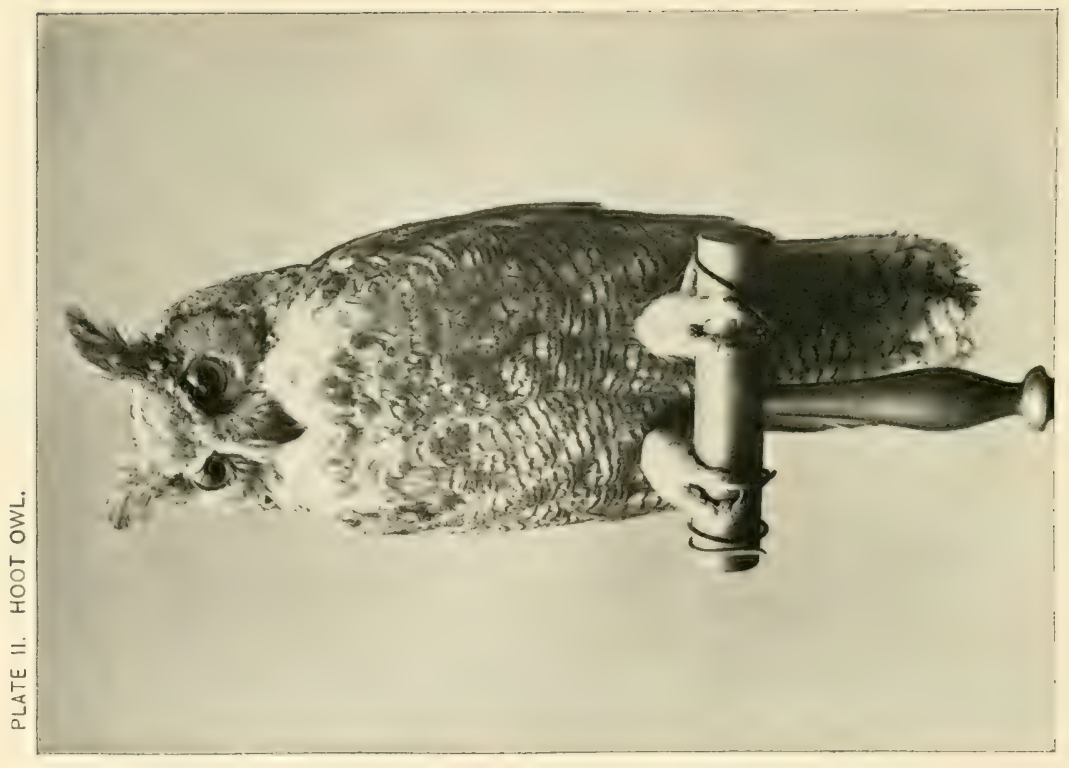




\section{PLATE II.-GREAT HOKNED OWL. HOOT OWL.}

\section{Bubo virginianus.}

Mottled all over with hrown, ara! tawmy and black: a light iollar about the throat : larese ears tufted : iris yellow: hill and clatws black. Length, 21-45 inches.

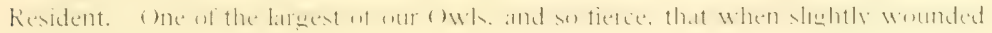
he is it formidable antagonist.

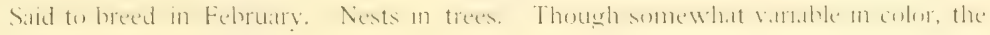
light collar is always present.

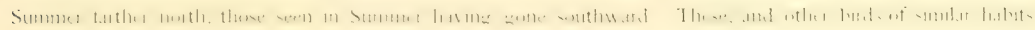
are here classed RESIDENT.

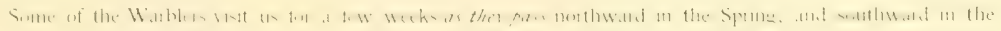

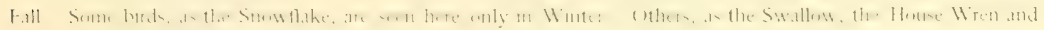
many more, come only in Summer. Birds with such habits are here classed Mickatory. 


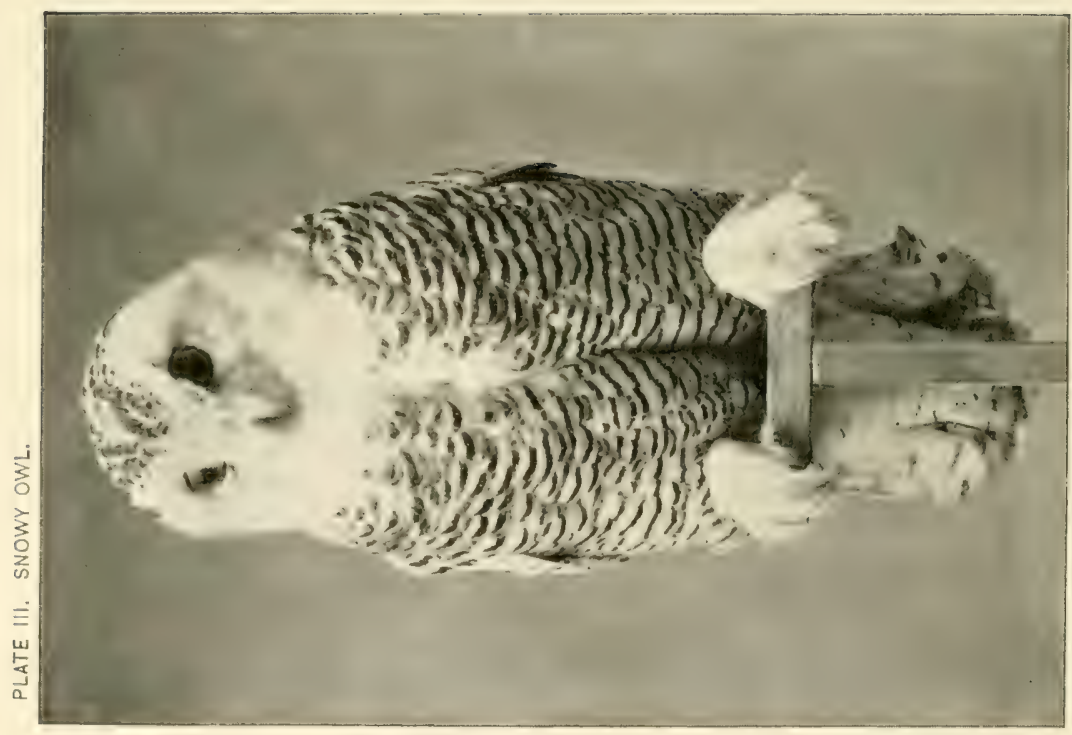




\section{IITIIE HORNEI) ()WL. S(REFEH ()WI. RII) ()WL.}

\section{Megascops asio.}

Mottled with black, hrown and graly : ears tufted: iris gellow: hill and claws horn color. Length, o. fu inches.

Resident. Breceds in stumps. holes of trees or in buldenes. The commonest ow we

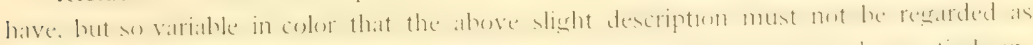

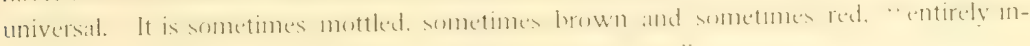
dependent," as I)r. Coues remarks, "of agre, season or sex."

\section{PLATE III.-SNOWY OWL.}

\section{Nyctea nyctea.}

White, spotted all over with hrown, except on ficce. throat and leass. which are immaculate : iris yellow: hill and claws dark. leneth, 23.50 inches. 


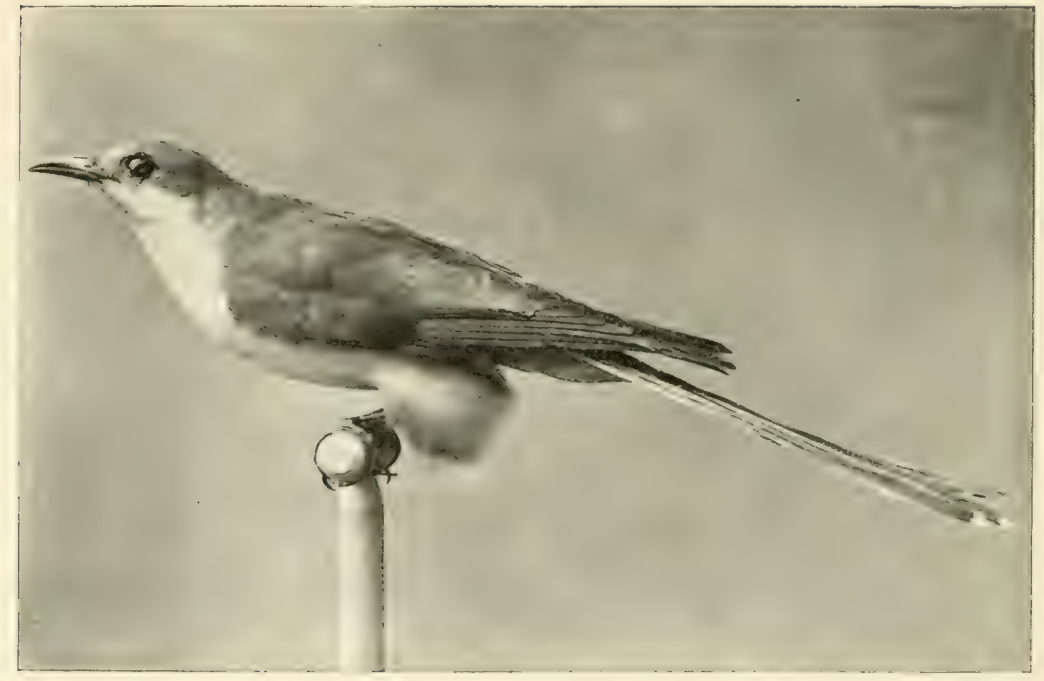


"This remarkable owl," says 1)r. Coues. "conspicuous in size and color alounds in the boreal regions of both hemispheres. Whence it comes southward irtegrularly in Winter. sometimes raiding in large numbers. W'ith us, it is of every Winter acturence in the North-

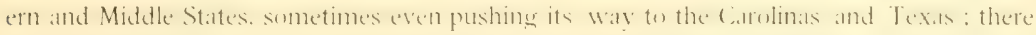
heimes no part of the United States where it men not appear at that season. It is lill fiom

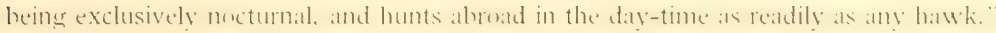

\section{PIATE IV.-BI.ACK-BII.L.FI) CUCK()( ).}

Coccyzus erytbropbthalmus.

Above olive-green: heneath white : a circle of red skin around the eve: bill black, long and arched: tail lomer and romeled. Leneth. 11.80 inches.

Mintatory. Arrives carly an May, leaves late in September. Nests in busher. Call kuli-kuk-kuk-kul, many times repeited. commencing rapidly, but with slower enunciation at the close. The sound does mot in the least sugresest the note of the Furopean variety. neither does it resemble the common pronunciation of its mame. It has a hoarse quality, 
however. which distinguishes it from the utterance of anv other hird. He who once hears the note will at once feel sure of its identity.

Mr. Burroughs wites of the Cukfor: " Nothwithstanding the disparity of size and color, the hlack-billed species has extain peculiarites that remind one of the pussengerpigeon.

"His eve. with its red circle. the shape of his heat, and his motions on alighting and taking tlight. guickly strgerest the resemblance; though in grate and speed, when on the wing. he is fir inferior. His tail seems disproportionately long. like that of the red thrush (Brown Thrasher). and his flugh among the trees is very still, contrasting strongly with the honest clitter of the robin or pigeon."

The Yellow-libled (ackon (Cocivas americanus) is at more southern bird. much less frequently seen here than the Black-billed. wheh it ilosely resembles. Its salient peculiarities are that it hats no red around the cres. its lower momdible is vellow, and it has large white blotches on the under side of its tail.

Its nest is very slightly comstructed and is commonly placed in a tree. 


\section{PLATE V. BFITHD KINGFISHER.}

\section{Ceryle alcron.}

Above ashy hlue: a hand of the simle aross the hreast : remainder of underparts and a spot hefore the eve white: tail syuare, handed and spotted with white: head large, and splendidly crested : hill lome. hlack : feet dark. Length, 13 inches.

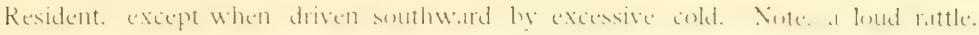
Nests in holes dug in a dre sandy honk. Its haunts ane bromks and river-banks. where it

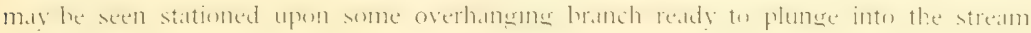
after its prey.

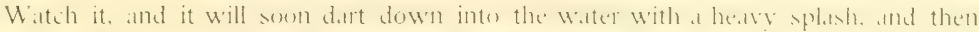
mount agan to its perch. sellevally hearing a fish in its heak. The tish is heaten upun the

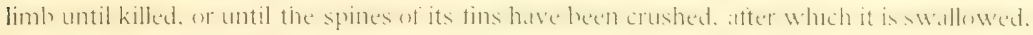

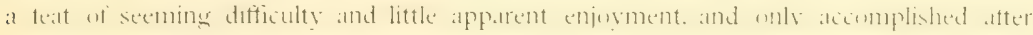

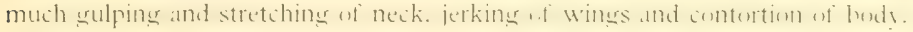

Now draw nearer. and the lurd will take ets lleght. sprongines its rattle whth aners in- 
PLATE V. BELTED KINGFISHER.

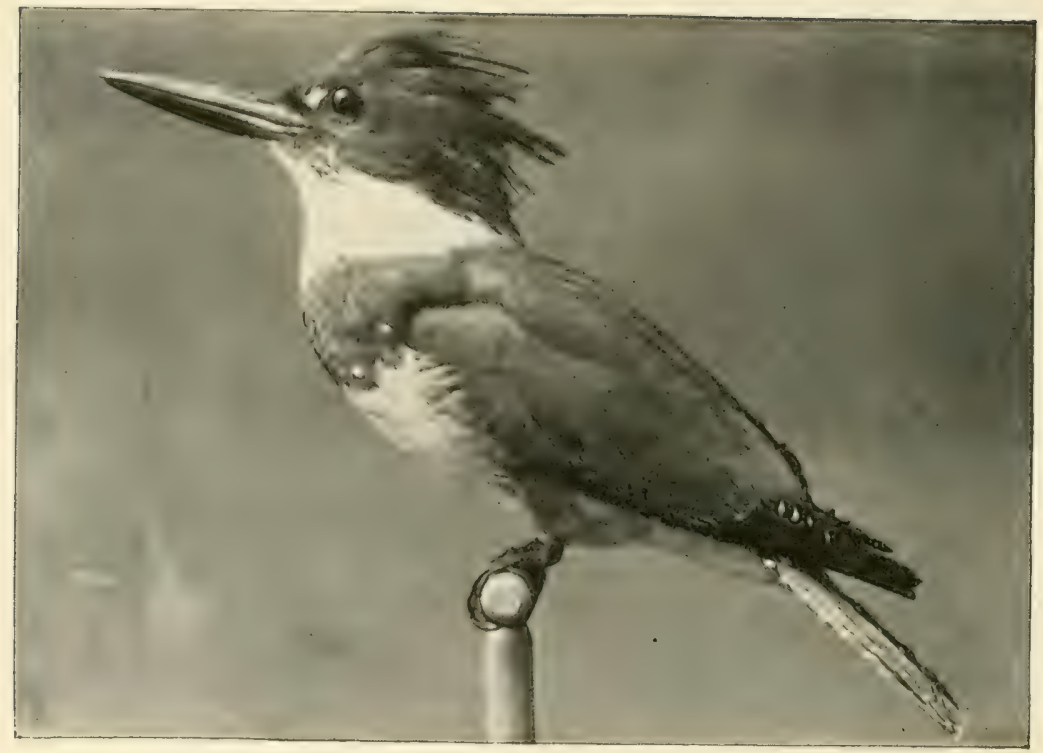


tonation as it groes. but alighting agrain at no great distane beyond. and always following the course of the stream.

Thus gently urged along. it will make many sucessive short tlights before taking its final departure.

The phrase "halcyon dilys" is derived from a legend comieming this bird. The Haleyon (Kingtisher), Was believed to huild its nest upon the walter, where. with its complement of egess it floated out to seas, the parent bird meanwhile brondinge and exerting the accult power possessed hy it of preventme stoms or tempests during the period of inculation. The continuance of this elemental peate and quietude was called " halcyon diays," and later. all times of trancjuility. Whether physical or moral, came to beall the same appellation. Another common. classical mention of the hingtisher. and more than once referred to by Shakespeate. indicates that the stuffed skin af this hird. suspended by a thread. Was used by the ancients as a weather-vane. (n) can readily prereive that the skin of a hird might he so adjusted that the heals must alwalys point to the somere of the wind. That the kingtisher alone was selected for thes purpose is probably due to its handsome appearance. and to the ease with which it would be possibie to discem the position of its beak and mannificent heald. 


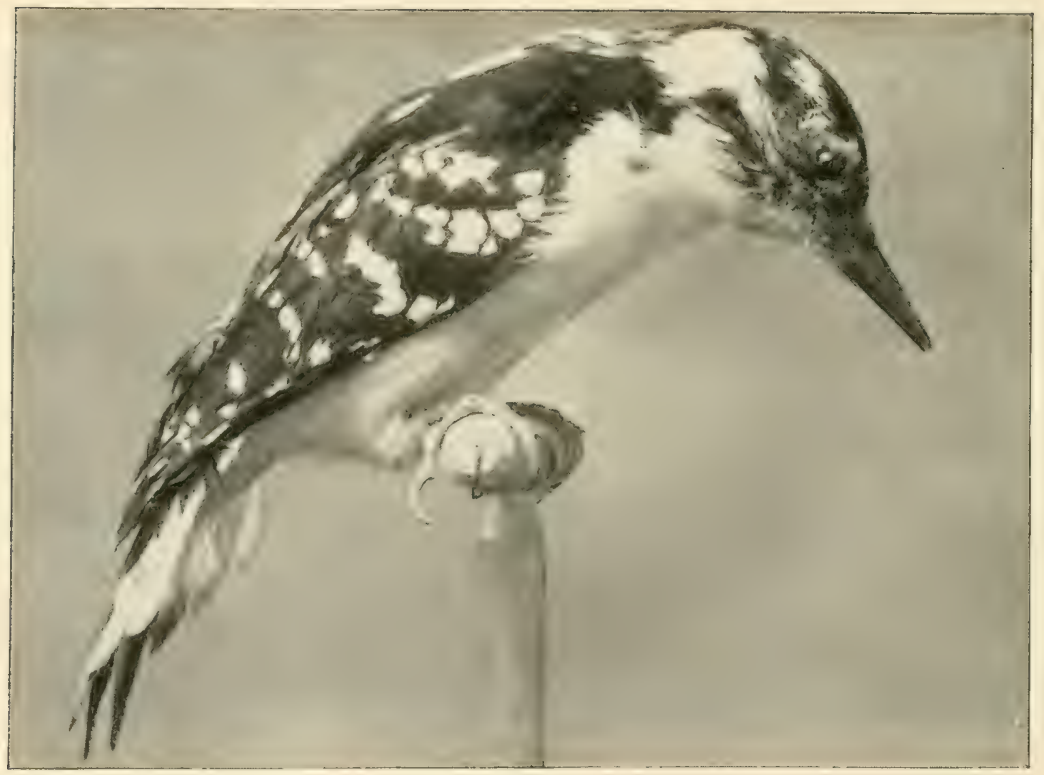




\section{PIATI: VI. - HAIRY W()DPPECKER.}

\section{Dryobates villosus.}

Head blakk, with a white streak under and one over the eye, and with a scarlet hand on the crown: hack black, with a white stripe down the centre- "the feathers composing this stripe are loose and nnwehbed, resembling hairs:" bemeath white: wings black, mach spotted with white: tail black, the two outer pairs of feathers white: hill and leus black. Length, 9.40 inches.

Resident. Flight undulatery. Nests in a hole which it has due in a thee stuated commonly in the woods. Its call is a harsh scream.

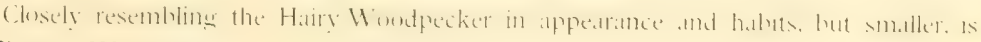
the DOWNy WOODPECKER (Dryobates pubescens).

A peculiarty of this hird. sufficient to prevent confoundung it wath the preceduns, is. that its white outer tail-feathers are barred with black. 


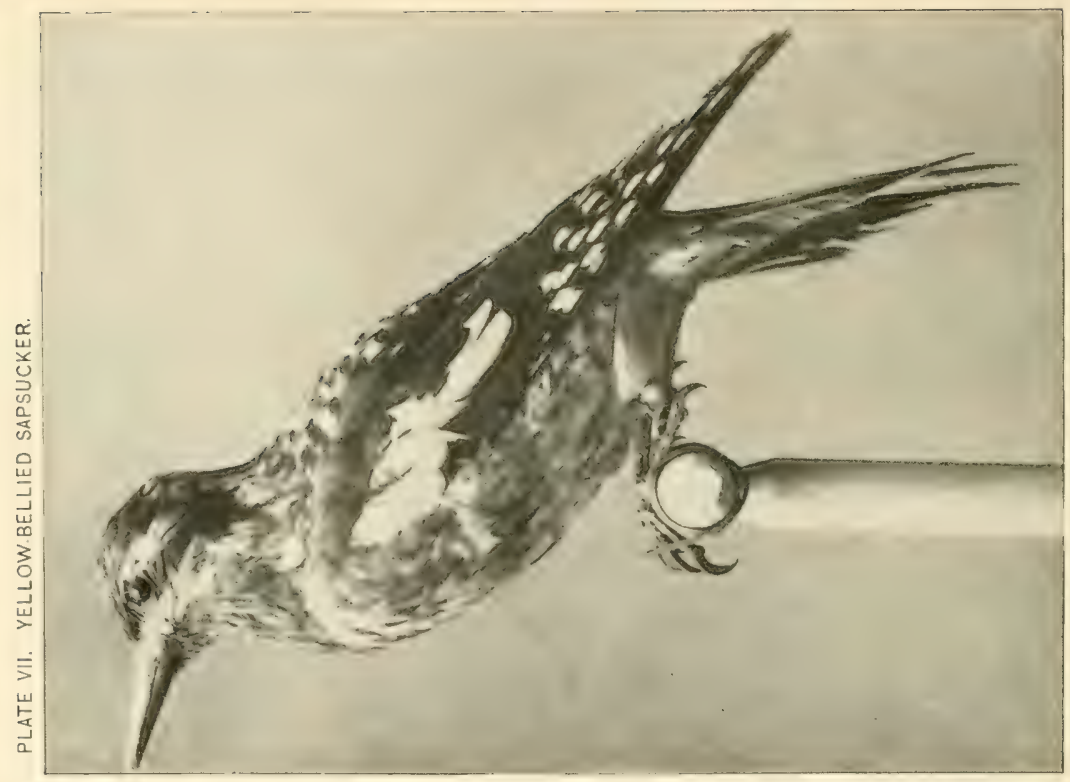




\section{PLATE VII-YFILOW-BELLIED WOODPECKER. YELLOW- BELLIED SAPSUCKER.}

Spbyrapicus varius.

Crown crimson, inclosed by a half-moon of black, and that similarly hordered for most of its circumference by a hand of yellowish-white: back mottled with hack and yellowish-white: sides of head yellowishwhite. cut by a black streak which passes through the eye: throat and upper-hreast hlack, with a large crimson patch on chin : remainder of under-parts yellowish-white. marked on the sides with brown: wings black, much barred, spotted and tipned with white: tail blakk, with a white streak down the centre. wedge-shaped, the feathers pointed and some of them bordered with white: bill and feet dark. lemgth, 8.55 inches.

The Yellow-beilied Sapsucker is represented here at all times of the year : hut only during Spring and Fall is it present in any considerable force.

Dr. Coues writes: " Birds of this remarkable genus feed much upon fruits as well as 


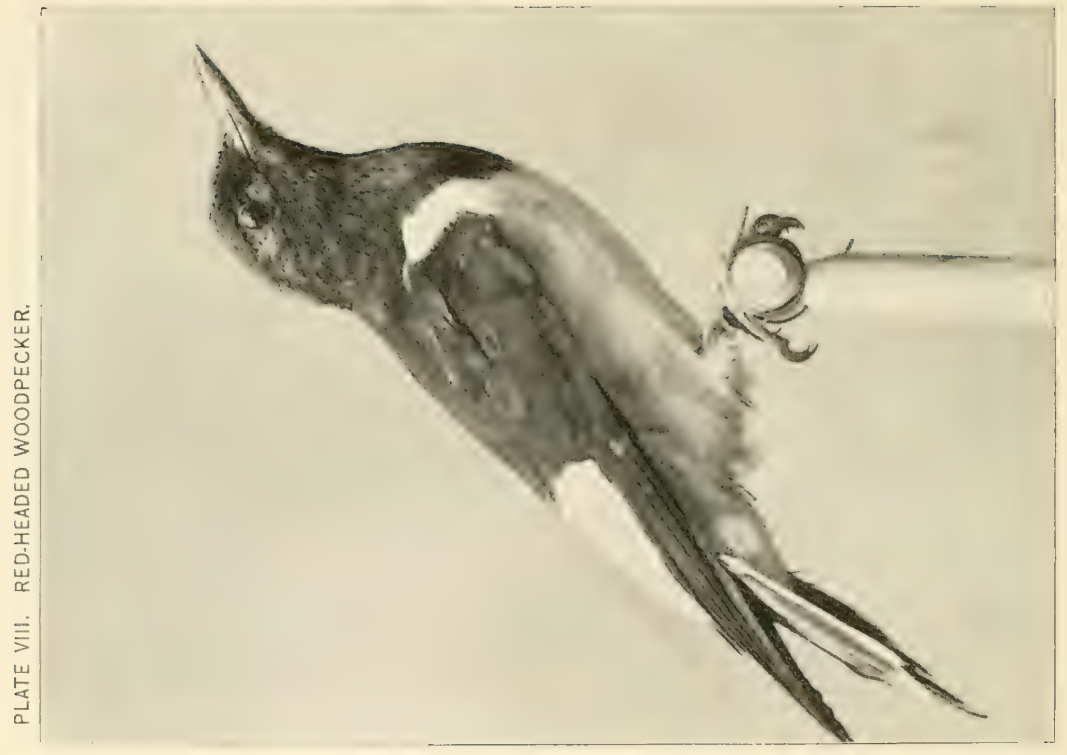




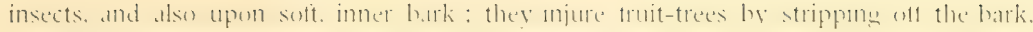
sometimes in large areas, instead of simply boring holes.

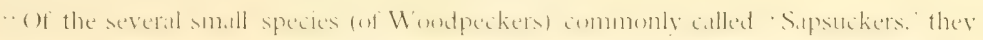

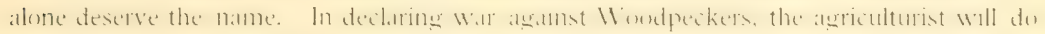

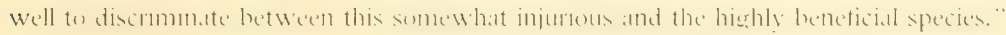

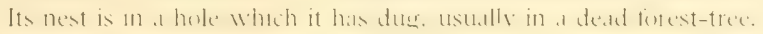

it has a number of harsh cries.

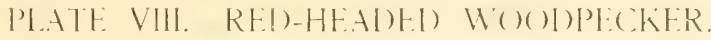

\section{Melanerpes erytbrocephalus.}

Head and meck all romud, crmmsn! lack lolack to rump, which is

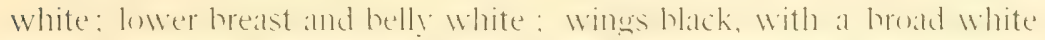
hand: tail black. sonewhat tipped with white. momded, and teathers pointed: hill and feet dark. lemgth. o. F inches.

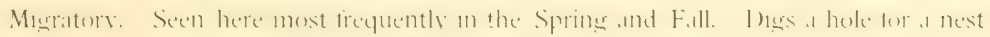

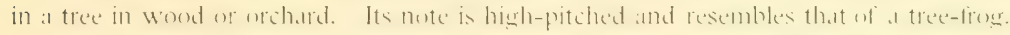

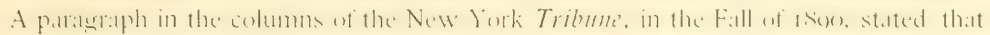

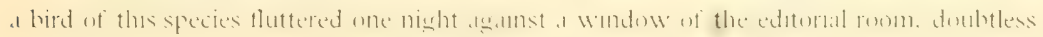




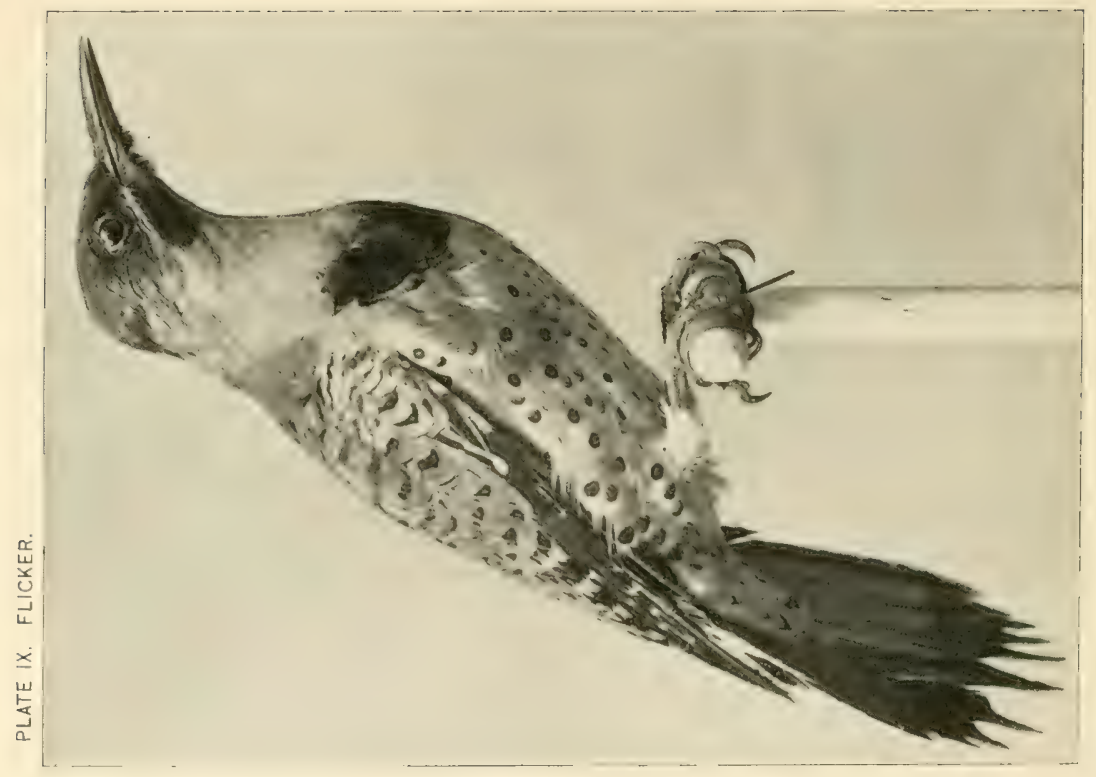


attrated and confused by the lights. The bird was admitted, allowed to rest, and then speeded on its way.

The writer was walking ane Autumn in the City Hall Park of New York City and observed a mumber of people eamestly rearading some object hien up on the trunk of at

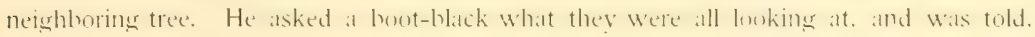
"A Woodchuck is up in that ere tree." Curious to witness a Wordehuck in so unusual a situation. the writer joined the concourse of grazers, and sonn pereeived a fine Red-headed Woodpecker clamber into sight from the further side of the tree-trunk. drumming assiduously and wholly unconscious of the excitement and interest he was provoking. Thinking

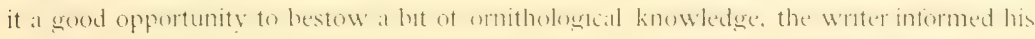
boot-black triend that the bird was a Wirexpecker. "() yes." wats the rejomder. "We" calls "em Woodchucks."

\section{PLATE IX.-FLICKER. G()IDEN-WINGEI) WOUDPF(KKER.} C.IAPE. HICH-HOLE.

\section{Colaptes auratus.}

Sides of head, throat and breast lilac-brown, with black patches on cheeks and a large black half-monn on breast : balck brown barred with 


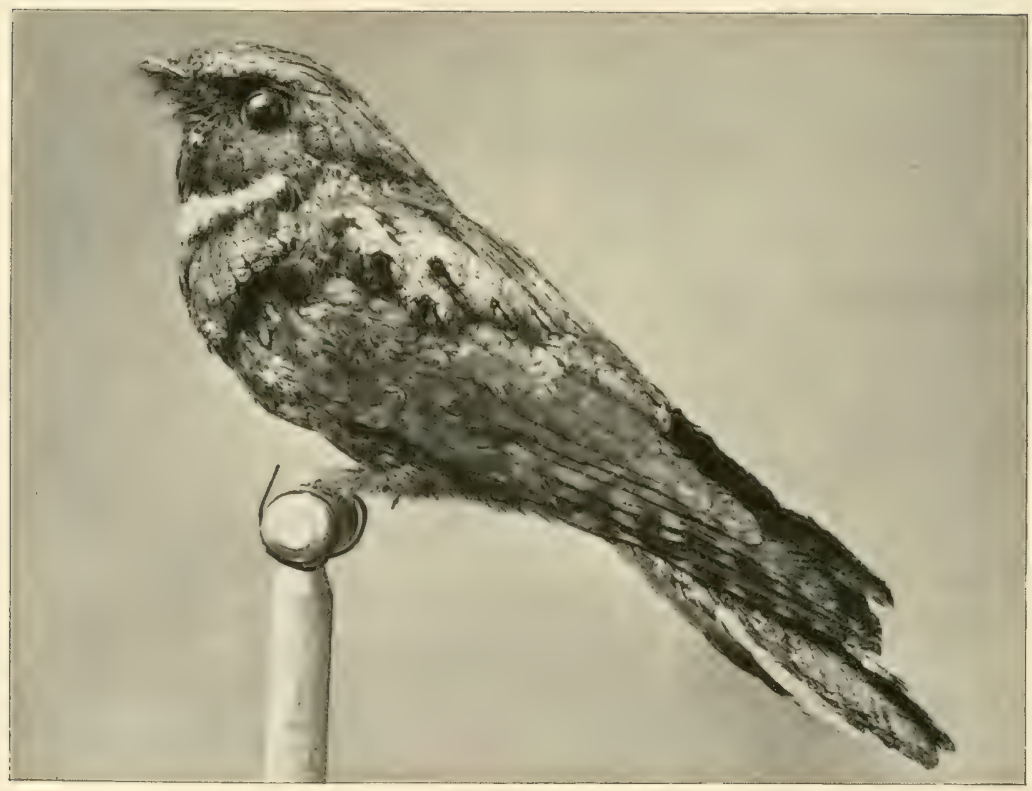


black: belly ashy, with many blak spots: tail blak aldowe, golden

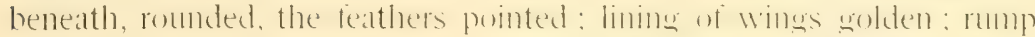
white: scirlet creseent on nitpe ; hill and feet dark. Length, 12.0o inches.

A resident species: the majority of them, however. coming in March and keaving by November. No hird has attrated more universal attention and interest than this one.

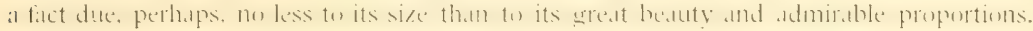

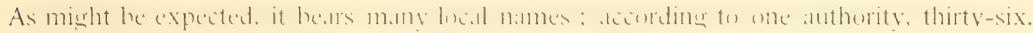

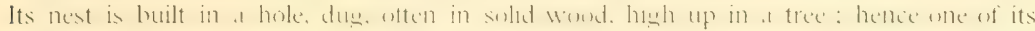
commonest popular names. High-hole. Aufuhom wrotes. "Its note is merriment itself,

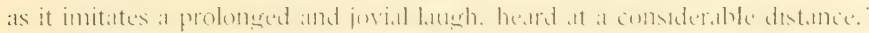

The black cessent an the lreast is vere prominent, and as dearly discomible when

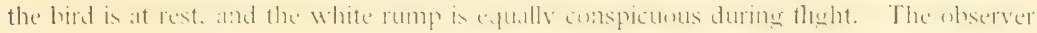
will tind mo difficulty in identifving this handsone species on sight.

\section{PLATE X.-WHIP-POOR-WILL.}

\section{Antrostomus vociferus.}

Mottled all over with redish-hrown, graly-blakk and soiled white: a white collar on neck: many bristles around the mouth: tail 


\section{PLATE XI. CHIMNEY SWIFT.}

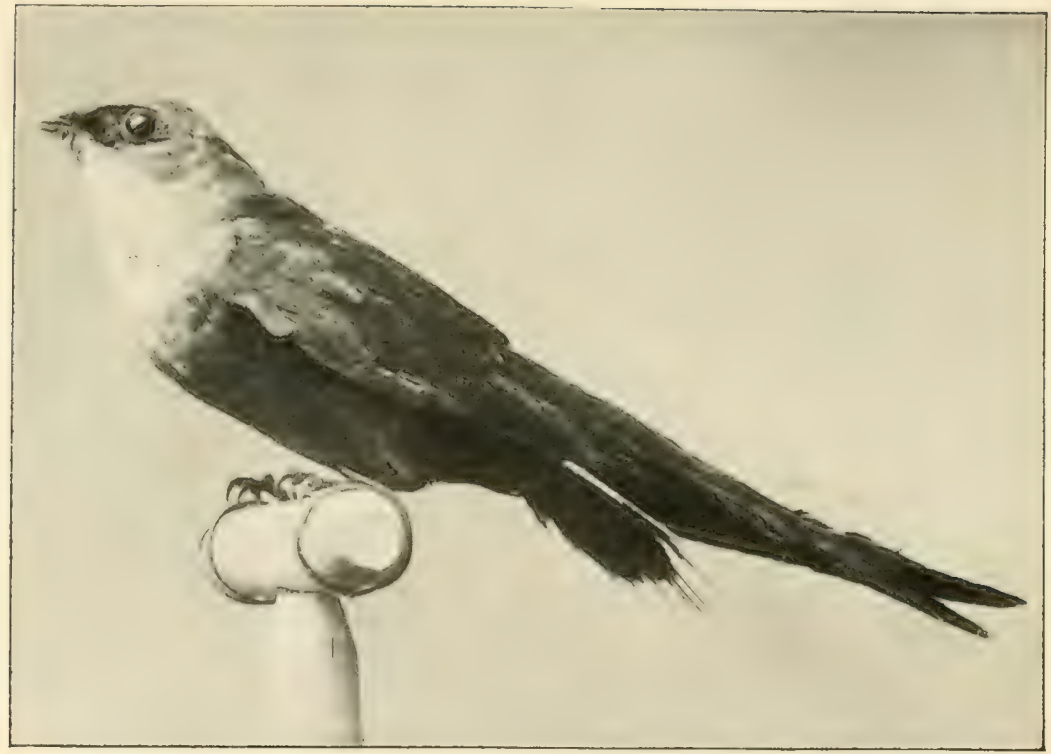


rounded and with patches of white on its under side. Length, 0.75 inches.

Migratory. Arrives early in Mas: kenses about the middke of September. Builds ne nest. hut lays its egers on the eround or upun a stump. It is a noctumath bird. lyinge closely in cover hy dily. and comseguentip mot often seen ; at night, however, its call, clearly suggresting its common names, is frequently heard. a mournful. hut not disigrevable, sound.

In cerenteral appearance the Whip-pent-will resembles the Night Hawk.

\section{PLATE XI.-CHIMNEY SWIFT.}

\section{Coctura pelagica.}

Sonty hrown all over except the throat, which is light gral : "yes surrounded by a hack skin: wings long. extending when folded heyomd the tail : tail short, spiny, square. Length, a.fo inches.

Migratory. Arrives here ahout Apral so, and kedres late in September. Although the Chimner Swift superficially resembles the Swallew: it. in fict. hols no reall atfinity with that bird. and the common practere of maming it a Swallow is an error. Its clesest affinity is with the Humminglird, which is its only superior in the art of flying. 
It inhabits chimmers or hollow trees, in which it builds nests of twigs glued together with its own salival.

Its note is a swallow-like twitter. and it is cyually voluble whether upen the wing or in its nest.

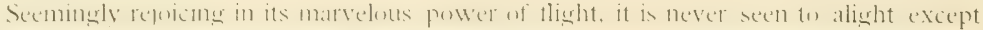

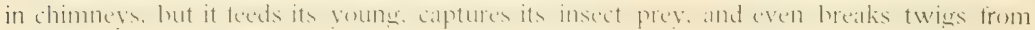
trees for nest construction while tlying.

\section{RUBY-THR()ATED) HUMMIN('BBIRI).}

\section{Trocbilus colubris.}

Above hright metallic ereen: beneath light grall: sides of body greenish : throat ruhy-red: wings and tail dusky violet, the latter deeply forked: hill straight. long and dilated at the tip. Length, i.j5 inches.

Mieratery. Arrives enly m Mal: keaves in September. Its nest. which is a tiny alfair, is usually placed on the upper side of a limb; it is made of lichens and is lined with vegetable down. 


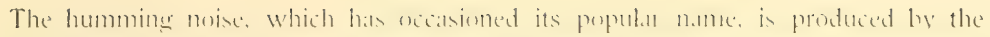

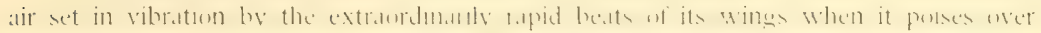

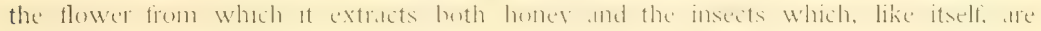

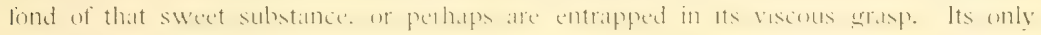
utterance is a sharp chirp or squeak.

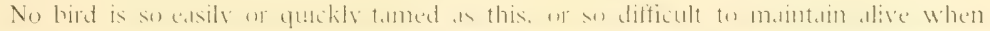

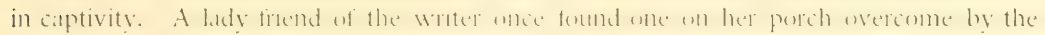
coldness of an unseasomathe Summer day. She teme it to her roum and revived it

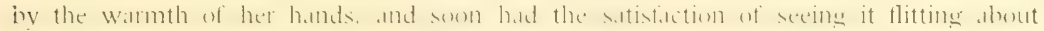
with apparent cherfulness. hovering wer some pofted plants af alighting on her hand

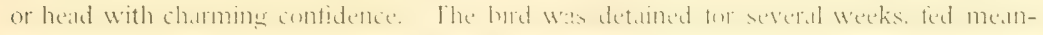
whike on sweetened water presented to it ly means of a medeine droppers, inter the tube of which it thrust its longe lull. prosing itsed in the ail for the aperation.

One tine. bright day it danted out through an opened wondow and was seen no more. 
PLATE XII. KINGBIRD.

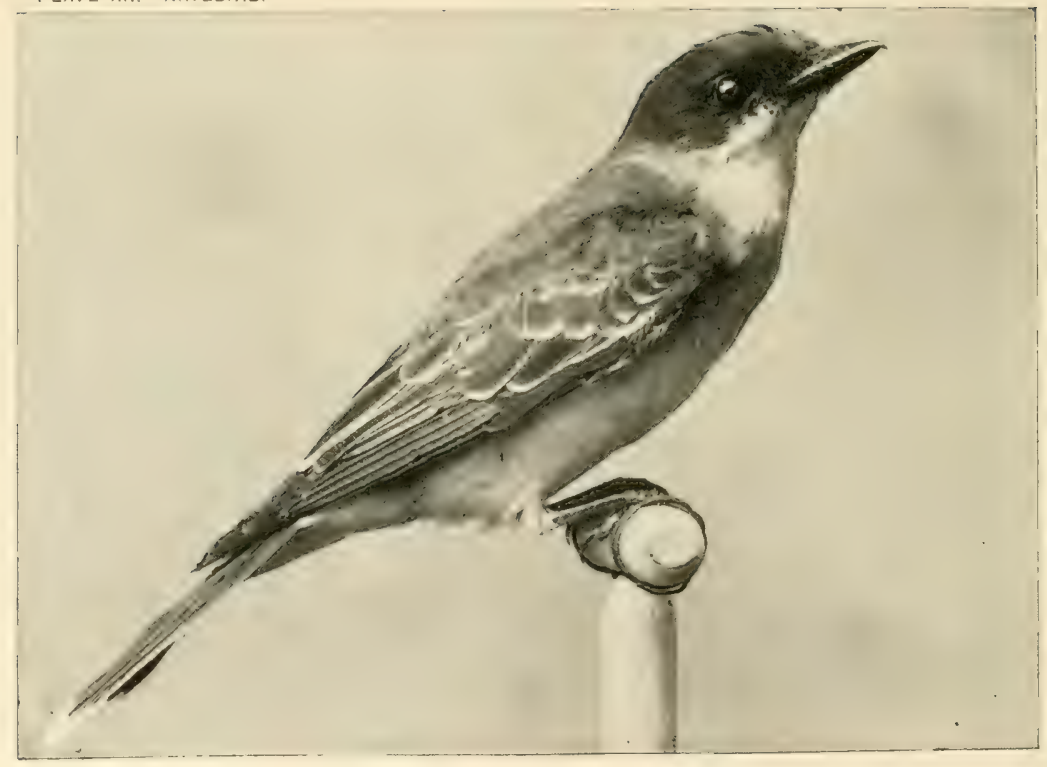




\section{l'ATI: XII. KIN(BBIRI), BLI-MARTIN.}

Trianmis trinthls.

Ahove dark ash: beneath white shated with light ash : heald hlakt. with an erectile crest in which is a spot of red: hail hlack sylatre and with a terminal white hand: wing-feathers moch edged with white: bill and feet black. Length, 8.50 inches.

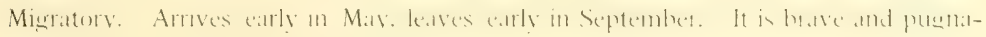
cious, bullying small birds and attacking large ones.

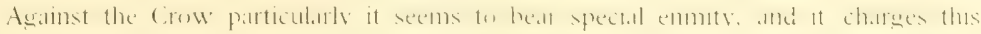

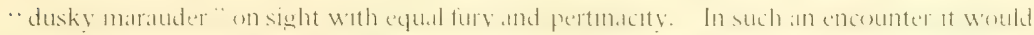

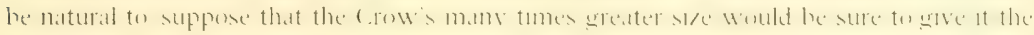
advantages This, however, is mot the case. I he erow does mot attempt oven to defend

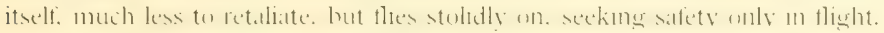

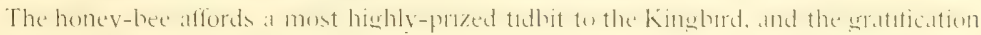

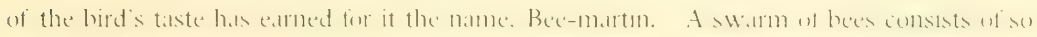

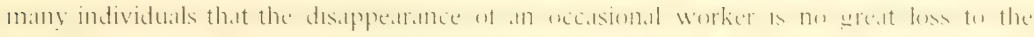

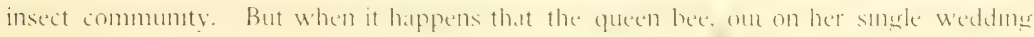




$$
\alpha
$$


thight, is snapped up by a discrimmating kinghind. then a calomity inded has befallen the swarm which can anle be remedied by manutiaturing another gueen, an operation in-

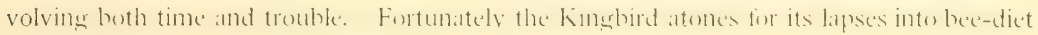
by devouring great quantities of harmful insects.

\section{PLATE XIII, CIREAT (CRFSTEI) FIYCATCHER.}

\section{Myiarchus crinitus.}

Above olive-ureen. darkest on the head. which is crested: throat and hreast ash : helly yellow: wings and tail reddish-hrown, the former with a pale, transverse bar, and the latter long and nearly even: bill and feet dark. Length, 9 inches.

Migratory. Arrives about May [0, leaves aluout September 25. Bunlds its nest in

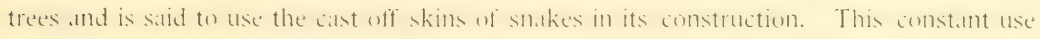
of snake-skins is commonly supposed to be in acondande with a desire to trighten off matraders by the displaty of what they shall haply take to be the live presente of their dreaded common enemy. A recent writer states that in all the nests of the cireat Crested Flycatcher found by him, onlv once wats the snake-skin absent, and, in this 
PLATE XIV. PHCEBE.

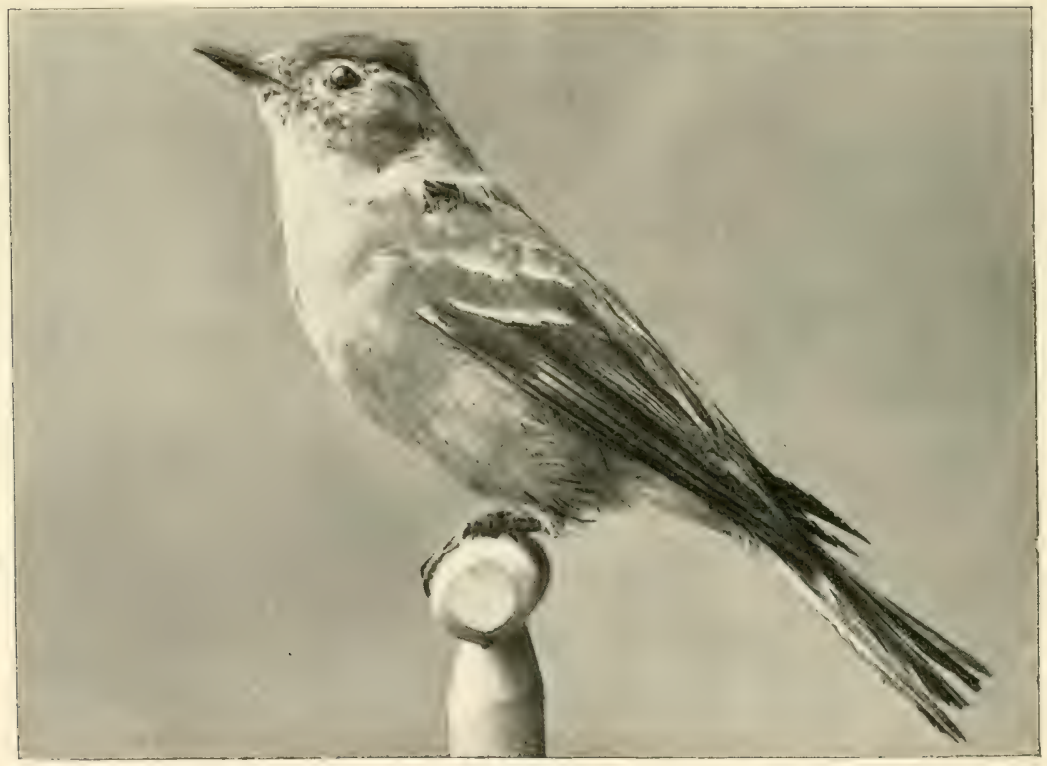




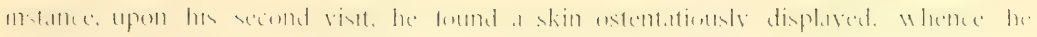

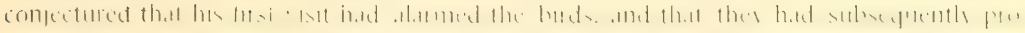

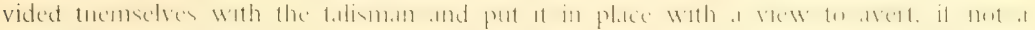

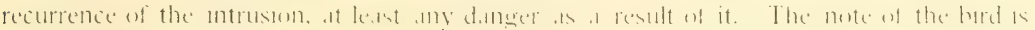
hatrsh and unmusical.

\section{PI.ATE XIV.-PHCEBE.}

Sayornis phobe.

Head dark hrown, with a slight erectile crest: hack and sides of body dull olive-brown: underparts soiled white with yellow tinges: wings and tail dusty, their feathers somewhat edeed with lighter: hill and feet black. Length, 7 inches.

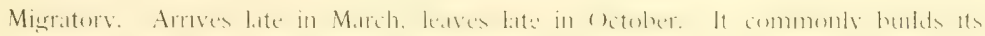
nest under the eives of buildings, or under a ledge of rock.

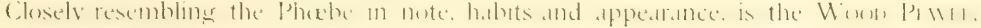

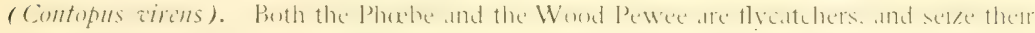

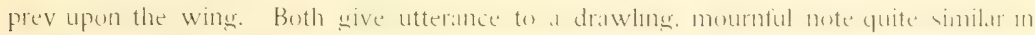

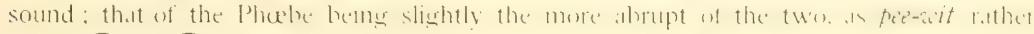
than pee-ee-wee-ee. 
PLATE XV. YELLOW-BELLIED FLYCATCHER.

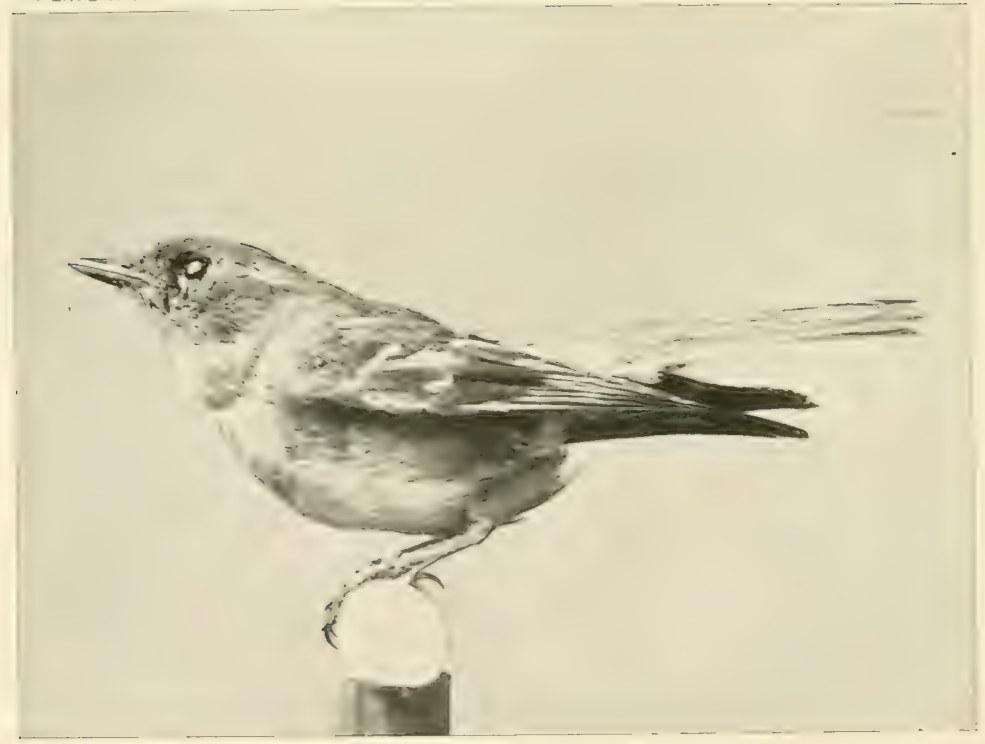




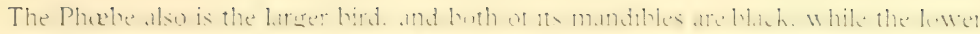

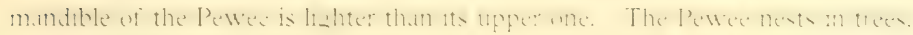

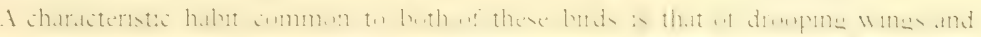

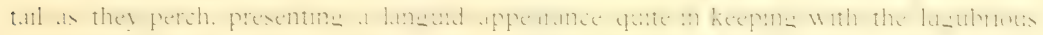

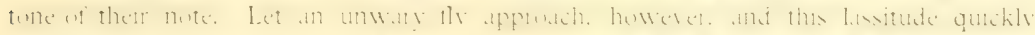

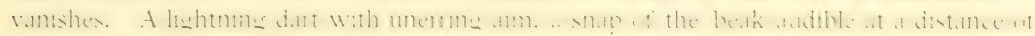

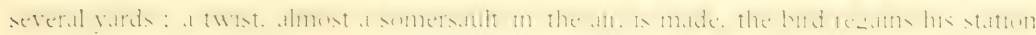

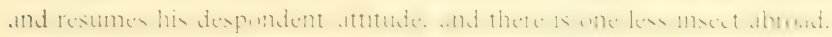

\section{PLATE XI:-YFILOM-BFIIIFI FICATCHFR.}

\section{Empidomax flaviventris.}

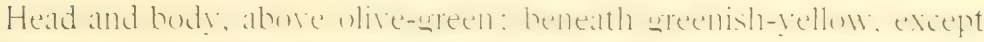

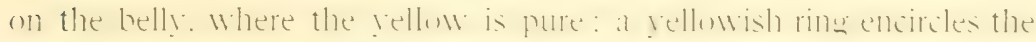

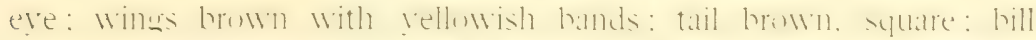

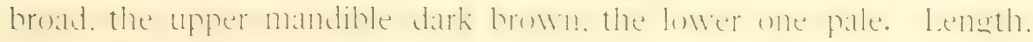
5.60 inches.

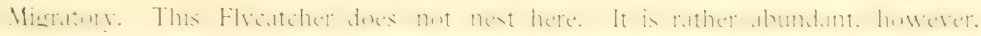

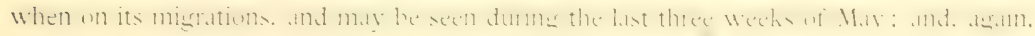




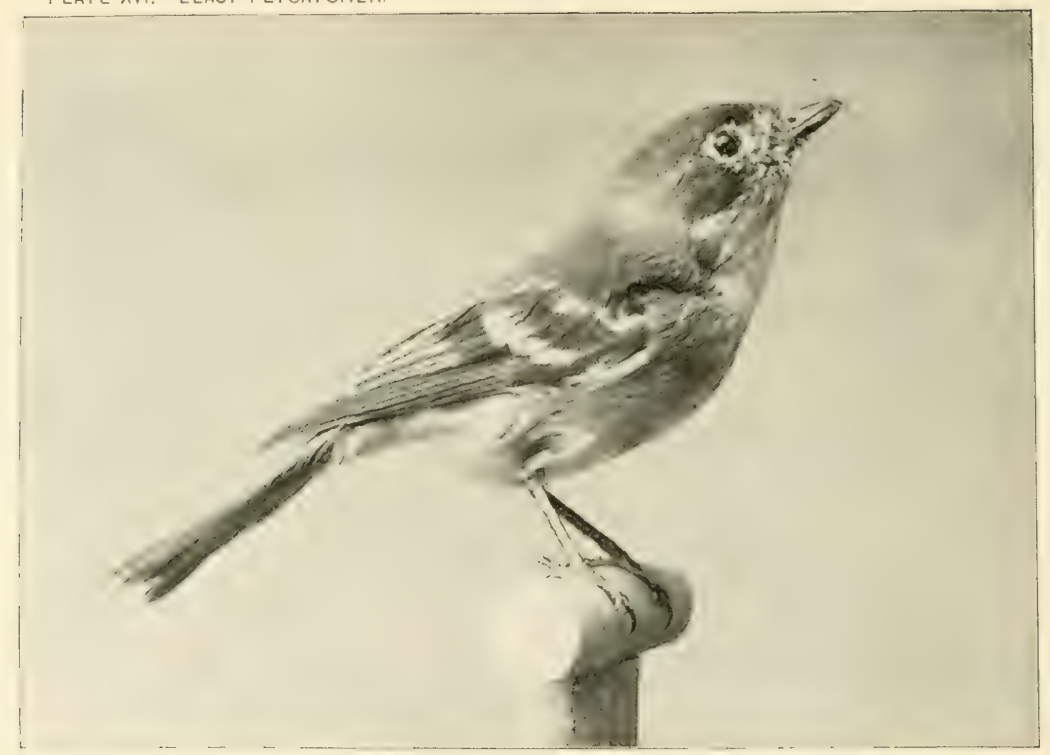




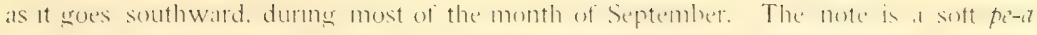

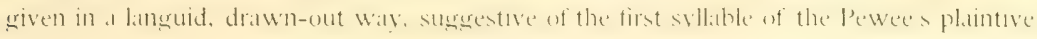
utterance.

\section{PLATE XVI.-LEAST FLYCATCHER.}

\section{Empidomax minimus.}

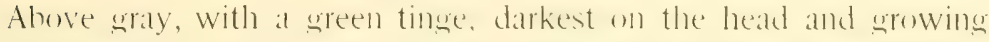
lighter towards the rump: heneath dull white, hout dirker and with olivateous tinges on the hreast and sides: a pale ring around the eye :

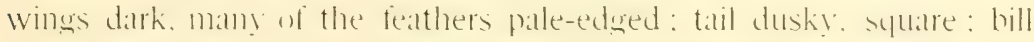
dark: feet black. Length, 5.40 inches.

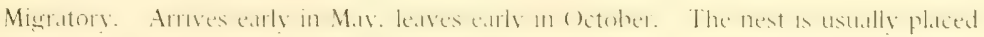

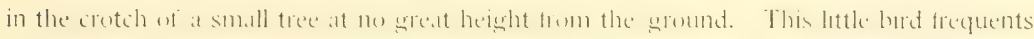

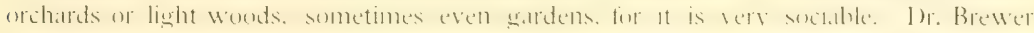

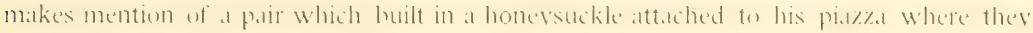

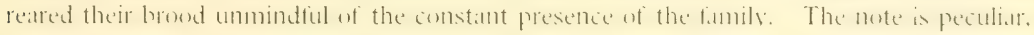

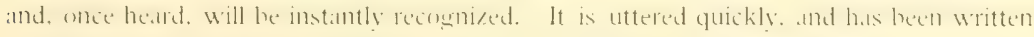
variously ats cheber, cadet and sewich. The first is chosest to the actend sound. 


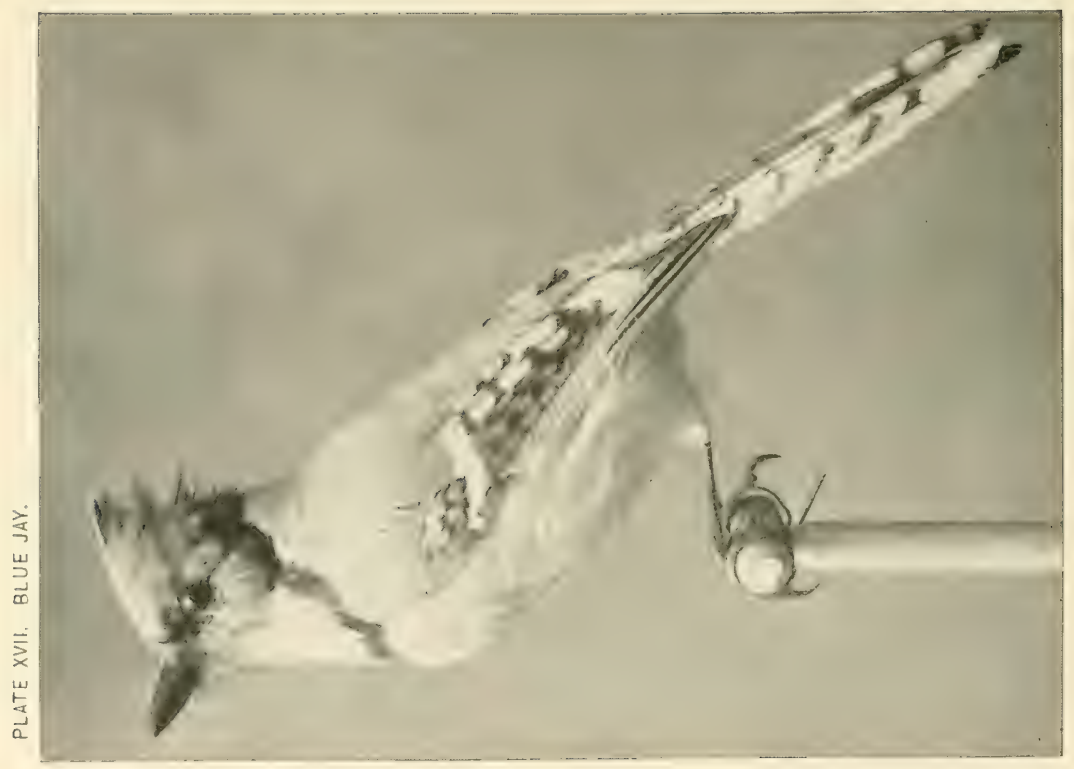




\section{PLATE XVII. BLUE JAY.}

Cjanocitfa cristata.

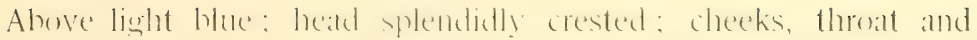
under-parts bluish white: wings and tail a darker hlue, bated with black, and many of the kathers broally tipped with white: a black

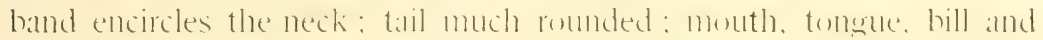
legs black. Length, 11.75 inches.

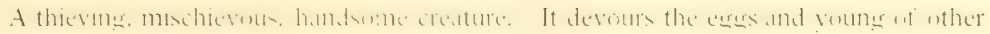

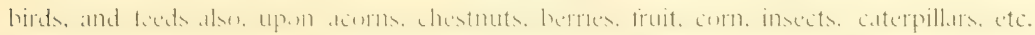

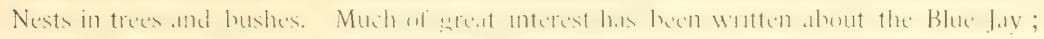

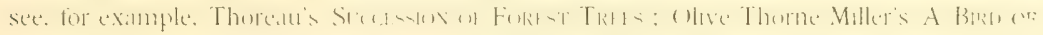

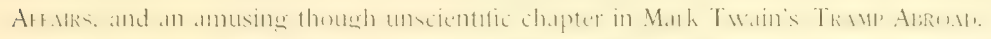

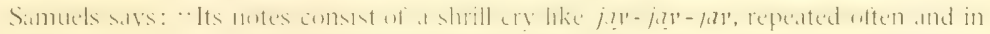

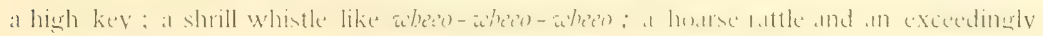
sweet, bell-like note."

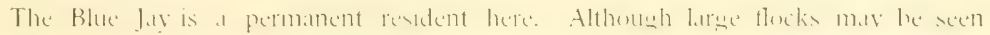
oroveling senthwated in the Autimn. the number of the birds deres not seem to be dimin-

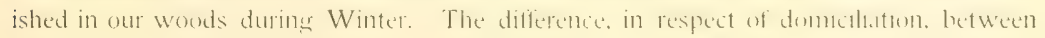




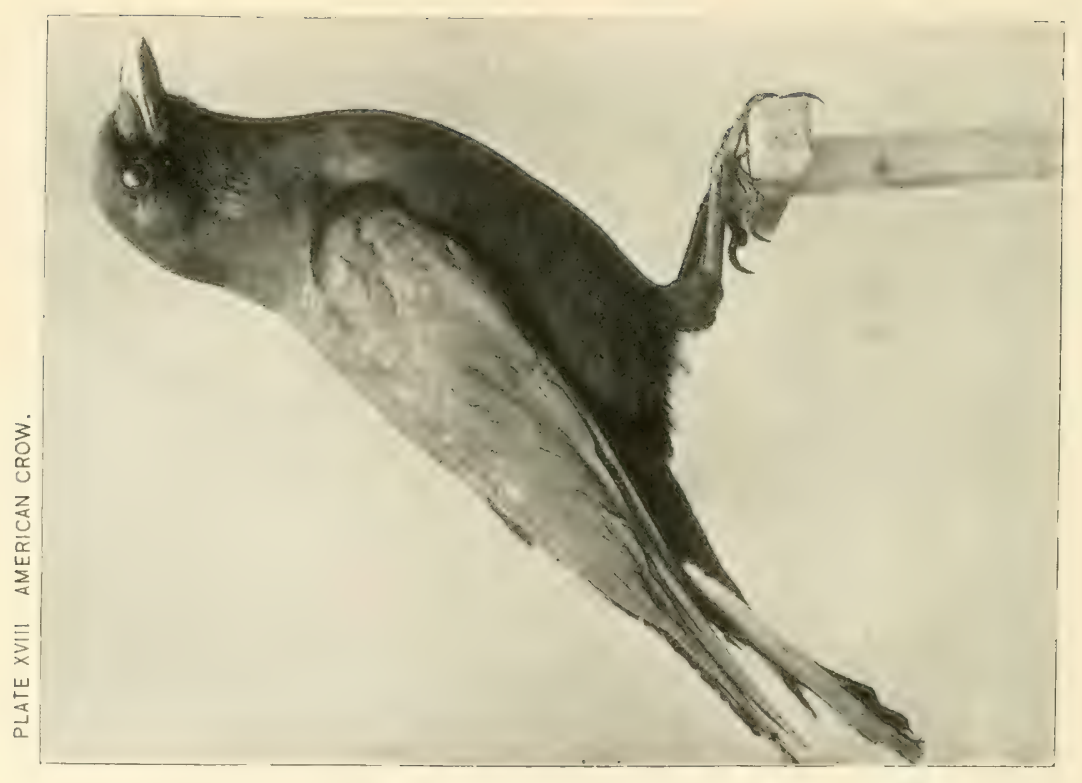




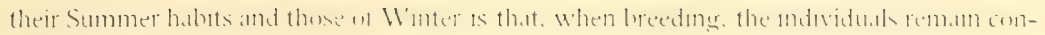

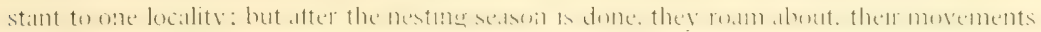

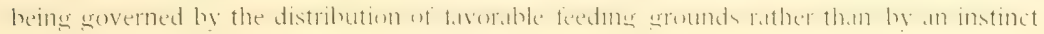
of migrition.

\section{PLATE XVIII. AMIRICAN CROM: CROW.}

\section{Corans americanus.}

No description is needed to idcontify this well-knomen hird. The

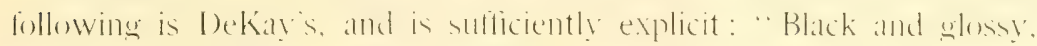

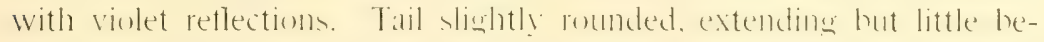

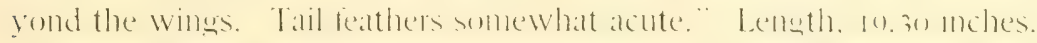

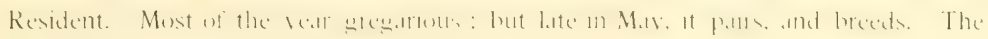
nest is roughly made of sticks, leaves and grass.

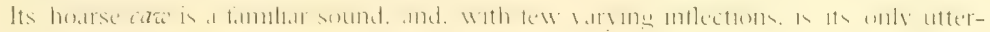
ance. A walker.

\section{HURNED LARK.}

\section{Otocoris alpestris.}

Above lilac-hrown, the feathers edged with a lighter timge, and the hrown on shoulders and rump redder than elsewhere: forchead, chin, 
PLATE XIX. BOBOLINK.

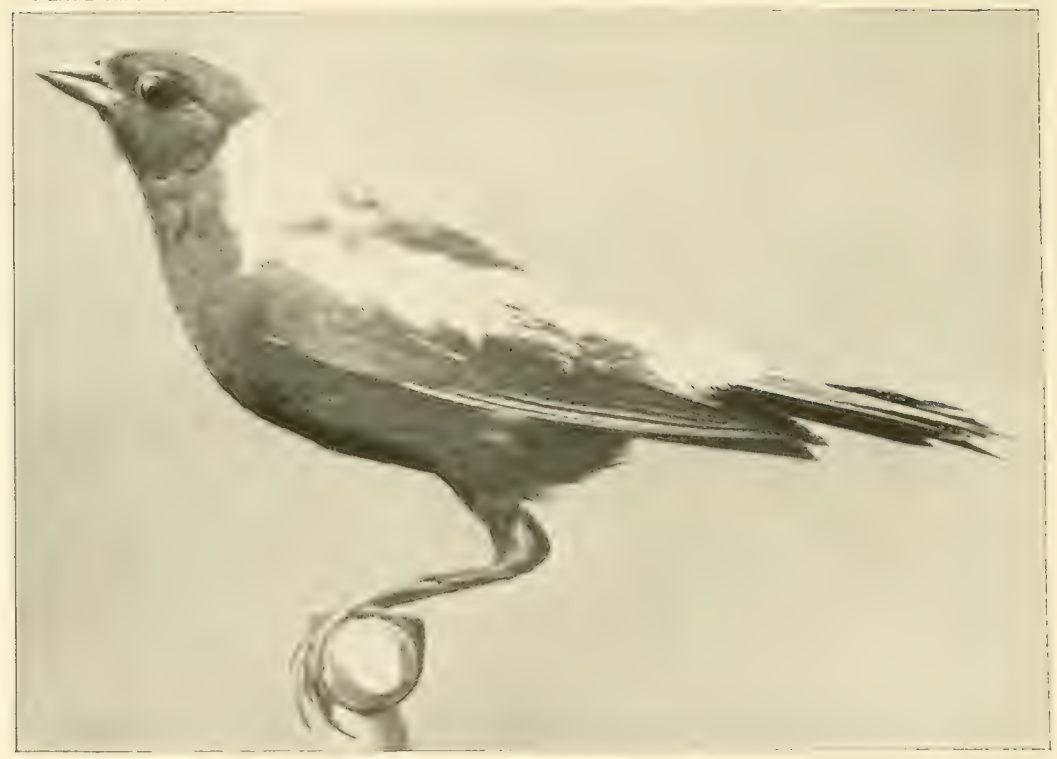


throat, and sides of head yellem: a blak stripe commenting at the

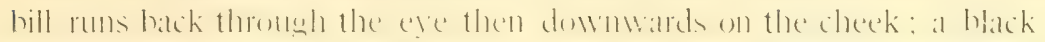

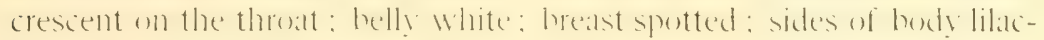
brown : a Mlack tuft on tach side of the head comected by a black

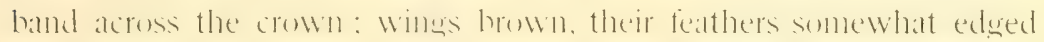
and tipped with lighter: tail notched, the middle feathers how

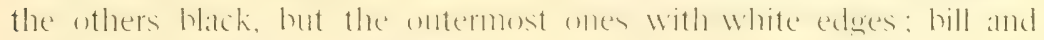
feet dark. Length, 7.25 inches.

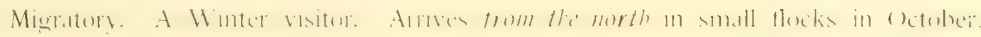
returns in March.

\section{PLATL: XIX. B()B(IINK. RFEI)BIRI).}

\section{Dolicbony:x oryzizorus.}

In Spring and Summer, hreast, wings and tail lolick: hind neck cream-color: back and rump white : hill and less hrown.

In Fall, yellowish-hrown, streatied with darker. leneth, 7.55 inches.

Migratory. Arrives early in May kave's late in September. Doring the breding 
PLATE XX. COWBIRD.

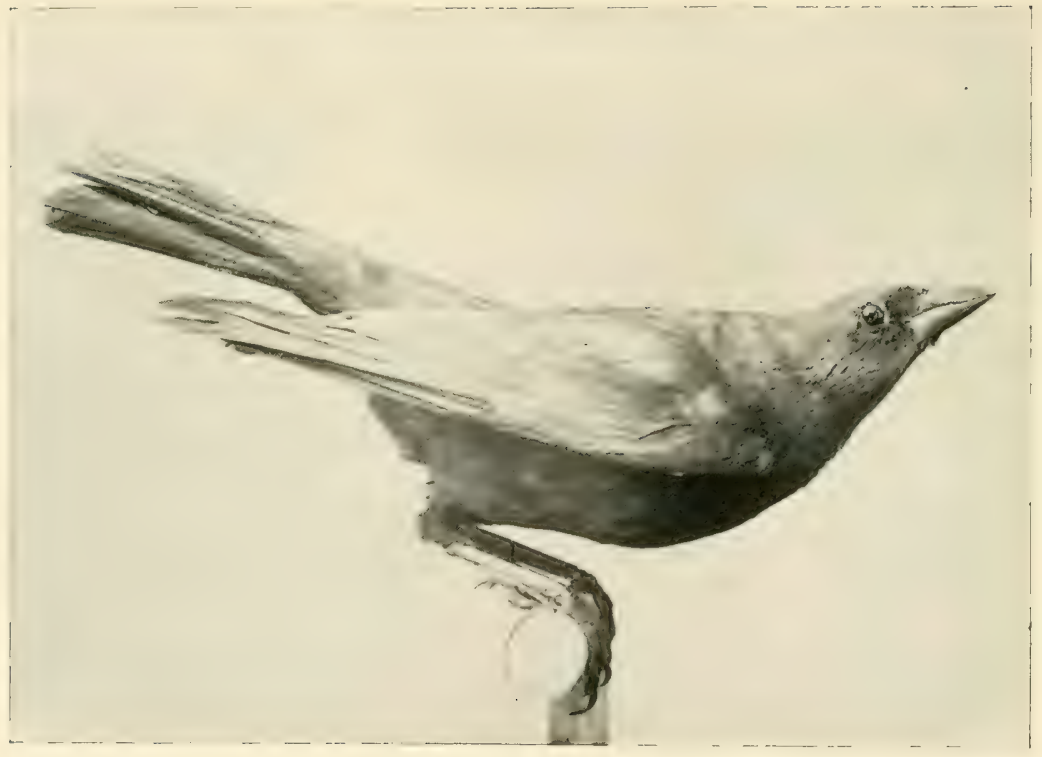


season a vigorous and persistent singer. Simuels calls its song " a most curnous, monm-

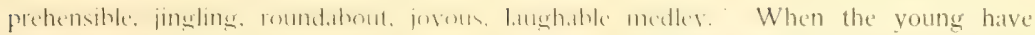

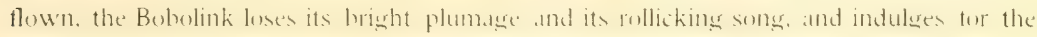
remainder of its sojoum in mothing more metodous than a pectulia ihirp.

A bird of the meadows, and nests upon the ground.

\section{PLATE XX - COWBIRD.}

\section{Molothrus ater.}

General color iridescent hlack: head and neck leep hrown: tail sepuare: hill and teet black. Length, 7.uo inches.

Migratory. Arrives early in April. leaves early in Oetoler. The lowhird deses mot pair, it huilds no nest, and the hatehing ot its exess is imposed upon some other bird alter

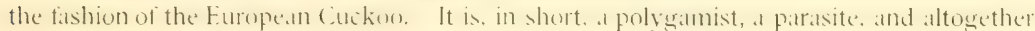
"at hird of loose principles." It is fomat in flocks, usually in the company of cattle. and hats a harsh call. sugeresting the syllables cheth-see-see. A walket. 
PLATE XXI. RED.WINGED BLACKBIRD.

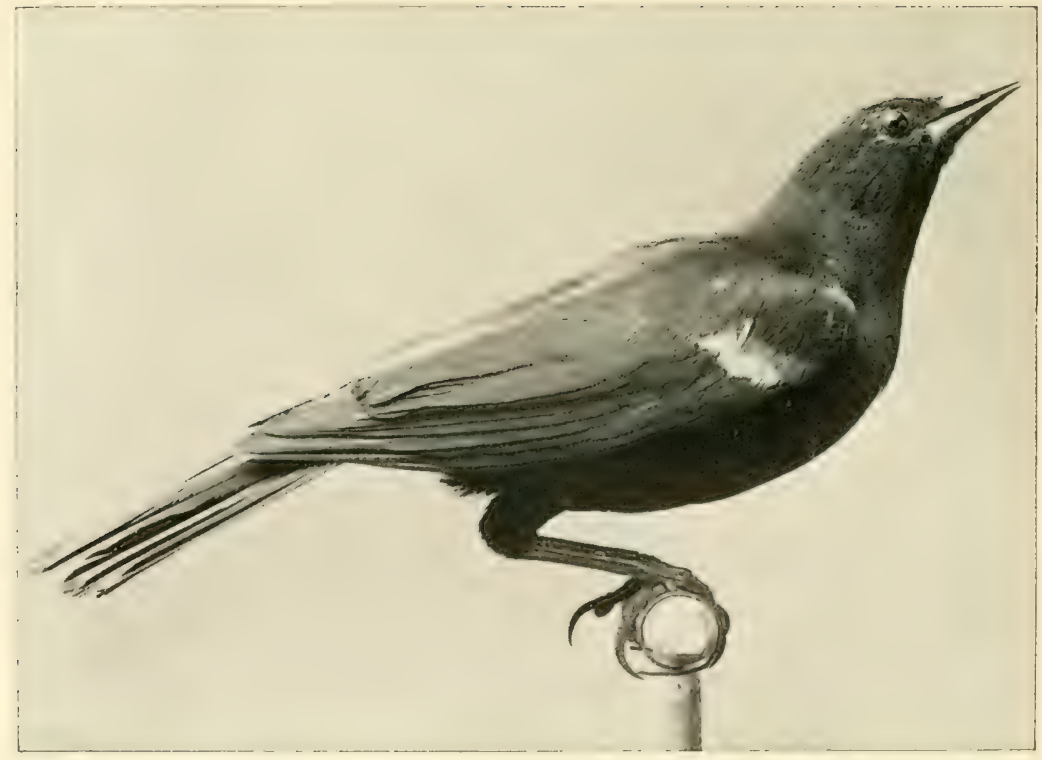




\section{PLATE XXI.-RED-W'INGED BLACKBIRD. \\ Agelailus phorniceus.}

General color back. With a ureenish lustre: shoulders crimson hordered with hulf: tail full and rounded: hill and legs llack, the former thick at the hase. Leneth, o, 50 inches.

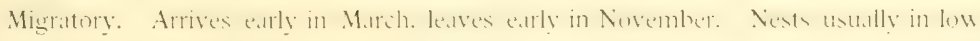
bushes in meadows or marshes.

Atter breeding. large tlocks onllect and are salid to consune great cuuntitics of grain. Its cill has been rendered quonk-a-ree. A walker. 


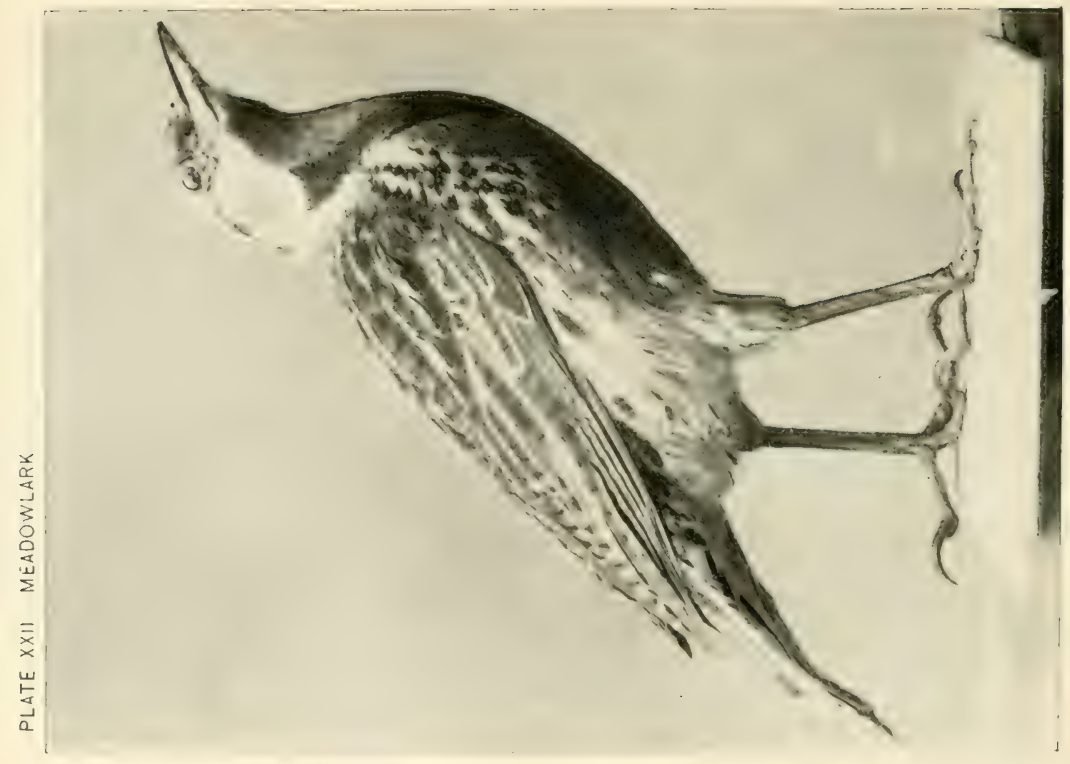




\section{PLATE XXII.-MEADOWLARK.}

\section{Sturnella magna.}

Back hrown spotted with hlack: heast hright yellow, with a large black crescent: a yellow stripe oner the eye and one on the crown: tail teathers pointed. the outer ones white : lews and feet flesh-color. Length. 10.75 inches.

Resident: though not numerom in Wimter. Most of these lurd come late in March and leave late in the Fall.

The Meradowlark nests on the ground in open tields. sometines in marshes. It is a walker and thes clumsily and with manitest labor. Its note is a plantive whistle. 
PLATE XXIII. ORCHARD ORIOLE.

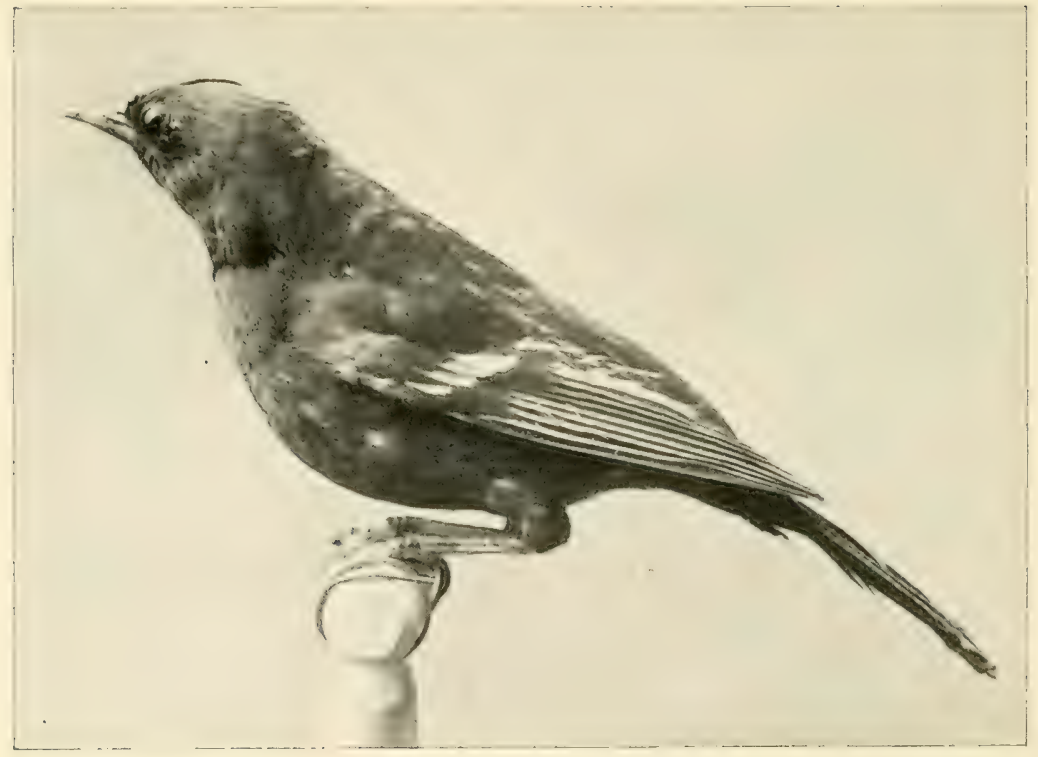




\section{PLATE XXIII.-ORCHARD ORIOLE.}

\section{lcterus spurius.}

Breast and belly chestnut : head, neck and upper-bati black: lowerback chestnut: wings back with chestmut shoulders and a transverse band. some of the yuills edged with lighter: tail rounded, hack, some of its cuills tipped with lighter: bill and feet, dark. Length. 7. io inches.

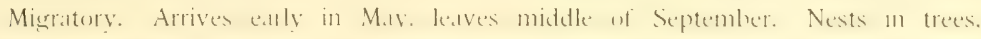
oftenest in orchards. The structure is woren in the sille manner als that of the Bablimere Orioles hut unlike the latter. it is placed upun the branch and is mot defendent from it. "The orchard Oriole." to quete Nuttall, " is an excedingly ative, sprightly amel restless bird: in the same instant. almust. he is on the sround after some fallen insede flutteringer amidst the folliage of the trees. pryine and springing after his lorking prey : or tlyings, and

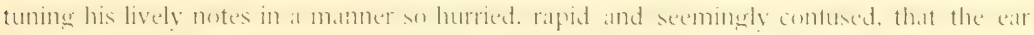

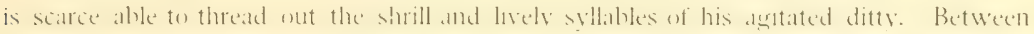
these hurried attempts, he also grves others which are distinct and anderable : hut still his tones are neither so full nor so mellow as those of the brilliant and gav Baltimere." 


\section{BALTIMURE ORIOLE. FIREBIRD.}

\section{Icterus galbula.}

Head, neck, throat and upper-hale lakt: lower-back, breast and belly brilliant orange: wines blakt. with a patih of orange on shoulders, a white transierse hand and some tippings and edgings of white: tail full, nearly spuare. With two latrese terminal patches of orange: feet and bill black. Length, 7.50 inches.

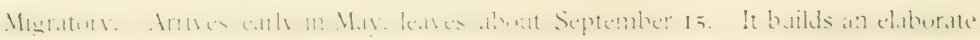

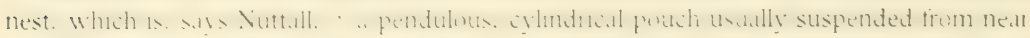

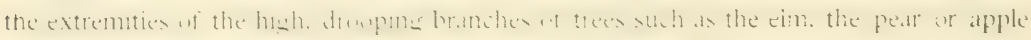

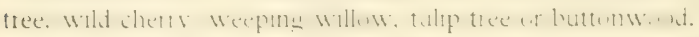

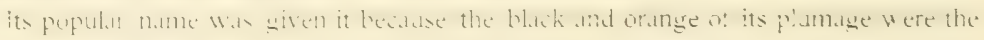
colors forming the livery of the first Lord Baltimore.

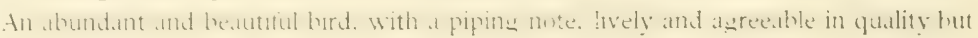
limited in scope.

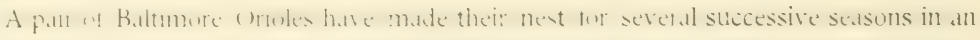
elm near the house in which the write has passed many Summers, and it is nectless to say 


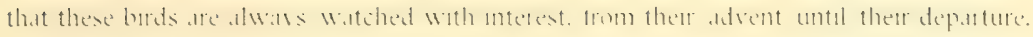
One murning the unusual ations of the demale led to the discosert that one of the young.

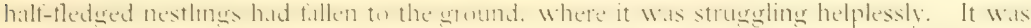

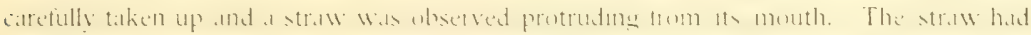

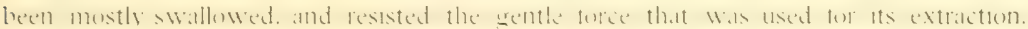

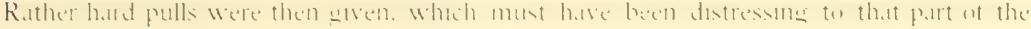

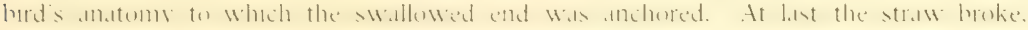

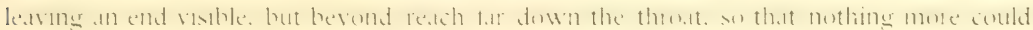

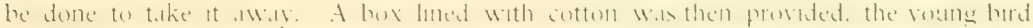

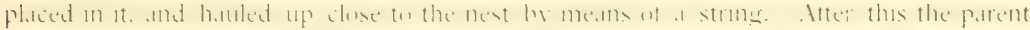

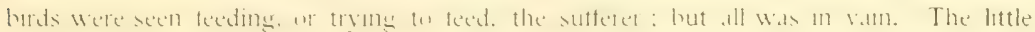
one died. 


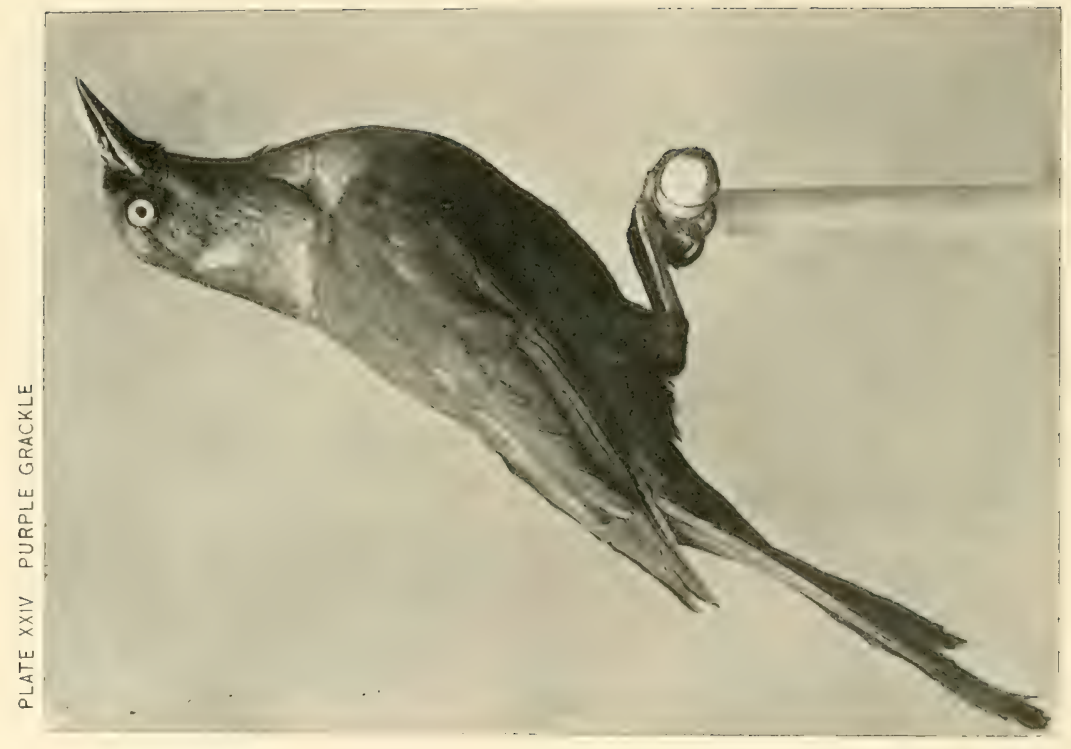




\section{PLATE XXIV. PURPLI: GRACKIE. COMMON CROW BLACKBIRD.}

\section{Quiscalus quiscula.}

Glossy hack all over: iridescent on head and neck: tail long and romaled: eyes light yellow: hill and feet black. Length. 1 2. $=0$ inches.

Migratory. Arrives carly in March. leaves early in November. Its nest is a roughly

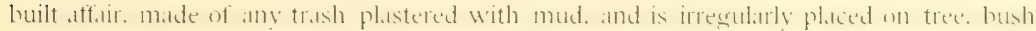

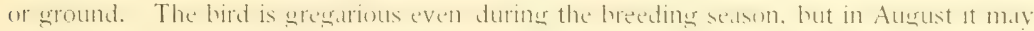
be seen in immense flecks, in company with equally lange numbers of Red-winged Black-

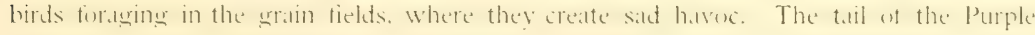
Gracke is what is colled a keel or boat-tail. It is very much rounded. and during tlight the outer quills slant upwards in such fashion as to cause a depressum in the eintere with a corresponding rise on each side. susgesting. it must be confessed remotely, the keet and sides of a boit.

The birds notes are harsh and discondant. and many of its attitudes are ungratceful, but. neverthetess. it is not without besuty. The sfoss of its black coat and the sheen of purple and woket. erreen and blue upon its head and breast, compel admiration. A walker. 
PLATE XXV. PURPLE FINCH.

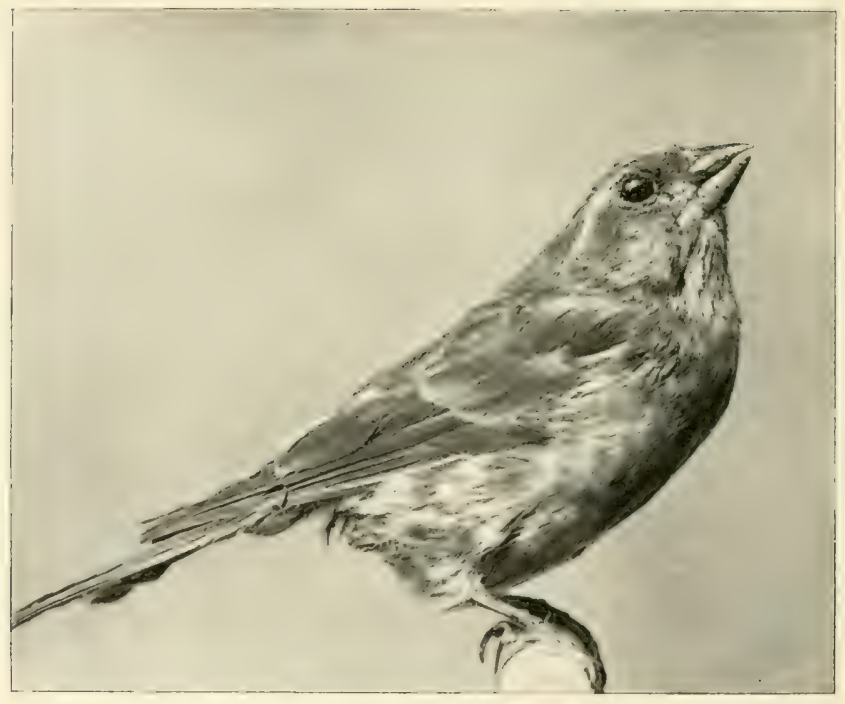




\section{PLATE XXV.--PURPLE FINCH.}

\section{Carpodacus purpureus.}

Body crimson, paler on rump and helly: back streaked with hrown: wings, hrown, some of the feathers edeed with reddish : tail, the same color as the wings, forked, hill concial. hom-color: feet brown. Length, 0.20 inches.

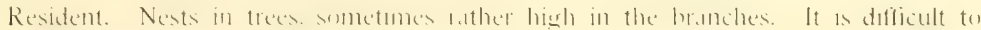

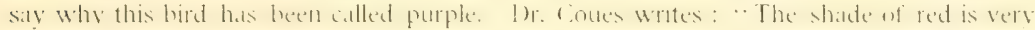

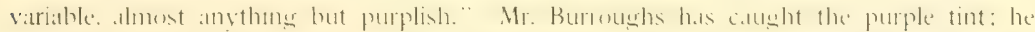

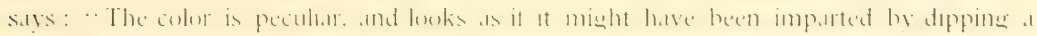

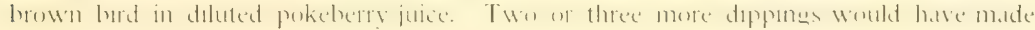
the purple complete."

The sonser of the leuple Finch is a chammer ane. Whath conpled with the gentle

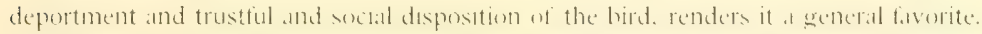

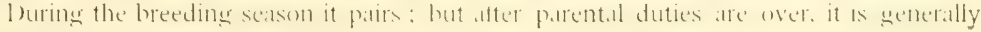
seen only in small tiocks. 
PLATE XXVI. AMERICAN CROSSBILL.

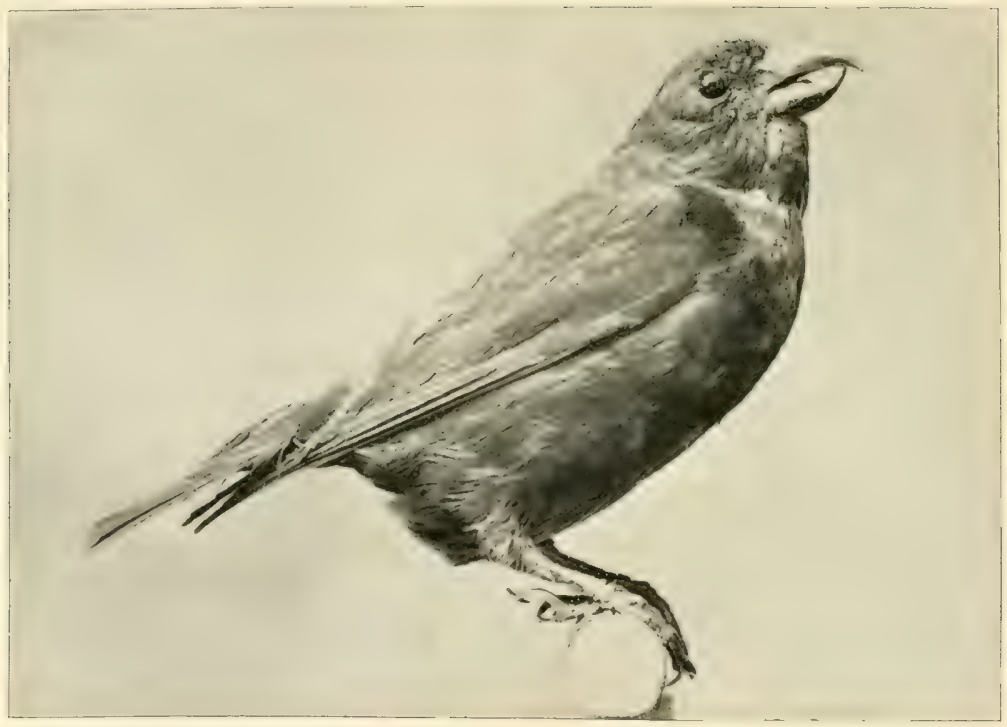




\section{PLATE XXVI, - AMERICAN CROSSBILL. RED) CROSSBILL.}

\section{Loxia curvirostra minor.}

General color red: darkest on the back, and with a gray tinge on the belly: wings and tail dark brown, the latter forked: mandibles crossed at tips. Length, 6.20 inches.

"Irregularly migratury," silys Dr. Coues, "aciording to exienencies of weather and food-supply, ** coming southward in flocks in the Fall."

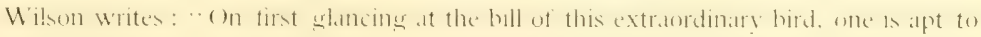
pronounce it deformed and menstrous : hut on attentively observing the use wh which is applicd by the owner. and the dexterity with which he detaches the seds of the pine-tree from the husks that encluse them. We are obliged to conless * * that mo other conformation could have heen serexcellently adapted to the pupose. * " It has a loud, sharp and not unmusical note. It chatters as it flies." 


\section{AMERICAN GOLDFINCH. YELLOWBIRD. THISTLEBIRD.}

\section{Spinus tristis.}

In Summer the body is bright yellow, shading to white towards the tail: crown black: wings black, some of the teathers edged witl white : tail the same. slightly forked ; lill and feet flesh-color.

In Fall it loses the black on the crown, and the vellow of the hody hecomes hrownish olive ahove, arigish-white helow, tinged with yellow. Length, 5.10 inches.

Resident. Nests in treas or tall bushes. Flught undulatery. It has several plaintive cills and a somer of comsidiande length but of little power. Which is sugerestive of the canary.

Care must be taken not to confeund the American (ioldtinch with the Summer Yellowhird. The two birds are not suffictently simula in appearance to make this caltion

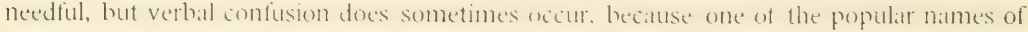
the American coldtinch is Yellowhird, while the most commonly used name of the Yellow Watbler is Summer Yellowbird. It would be well it the example of the A. () U. (heck- 


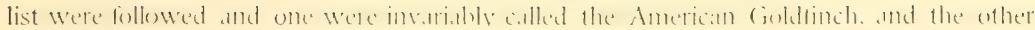
the Yellow Warbler.

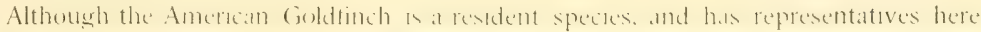

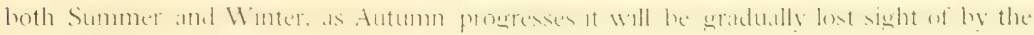
observer who is a hesinner. But as the coldtinch has faded from sight. an unfamiliar bird, apparently a new comser. will hate challenesed attentem a small hird, vellowish?-

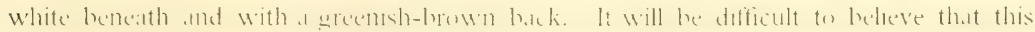

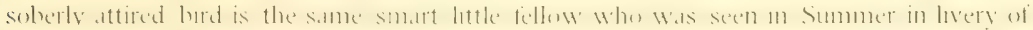

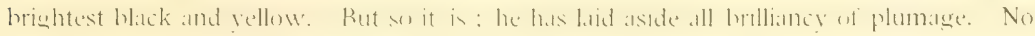

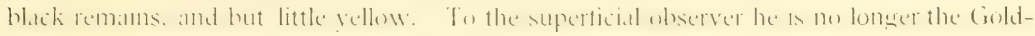
finch. but. an unkmown. insignticant. unnterestme little bowmss bird.

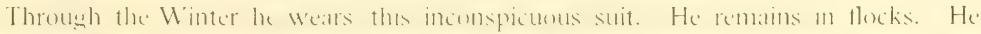

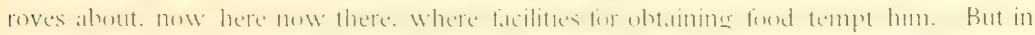
Spring. when the demdelioms show yellows se does he. Then he me honger roves in

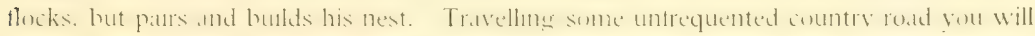

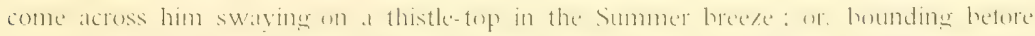

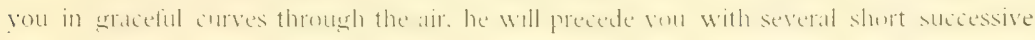
flights as you saunter along; no brighter, cheerier, prettier creature alive than he. 


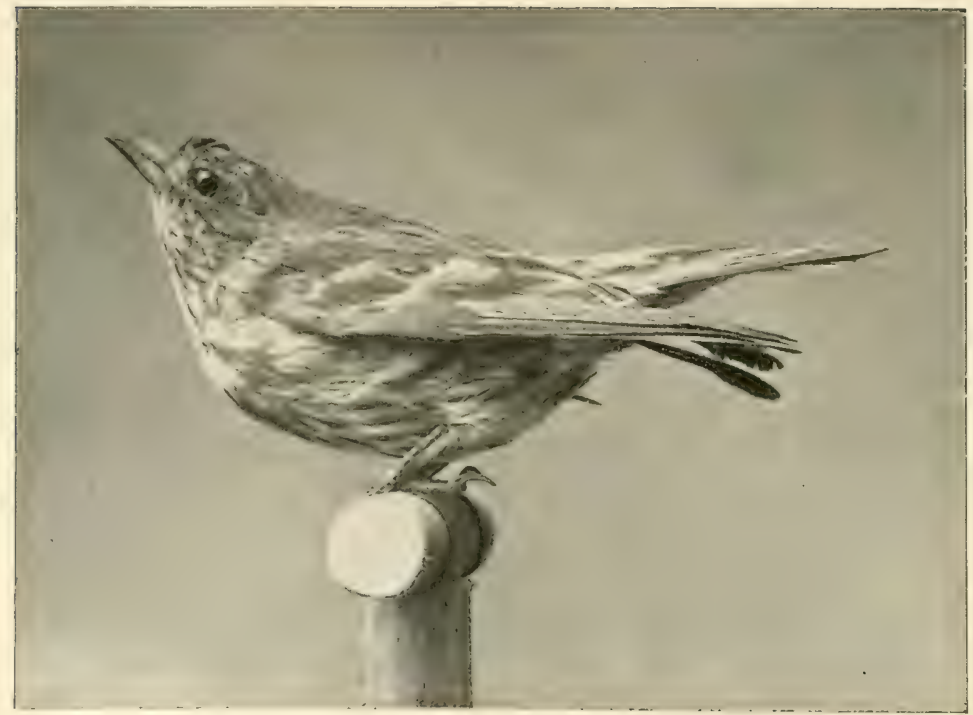




\section{PLATE XXVII. -PINE SISKIN. PINE FINCH. PINE I.INNET.}

\section{Spinus pinus.}

Above streaked with greenish-brown and dingy white: heneath dingy white streaked with light hrown: wings dosky. with two light bands and many of the feathers edged with lighter: tail dusky, the feathers with lighter edges, forked: the whole holy has a tinge of yellow, most noticeable on the rump and on the tail-feathers: bill and feet brown. Length, 4.75 inches.

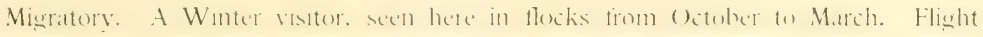

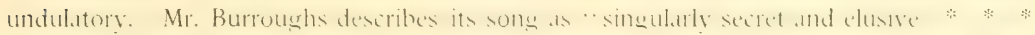

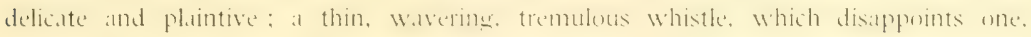
however, as it ends when it scems only to have lesun." He elsewhere calls this Find : "A dark brown or brindlish hird allied to the commen Yellowhird, which it much resembles in its mamners and habits." It nests in trees. and. contommbly to the suggestion conveyed by its n.mme, oftenest in those of the pine species. 


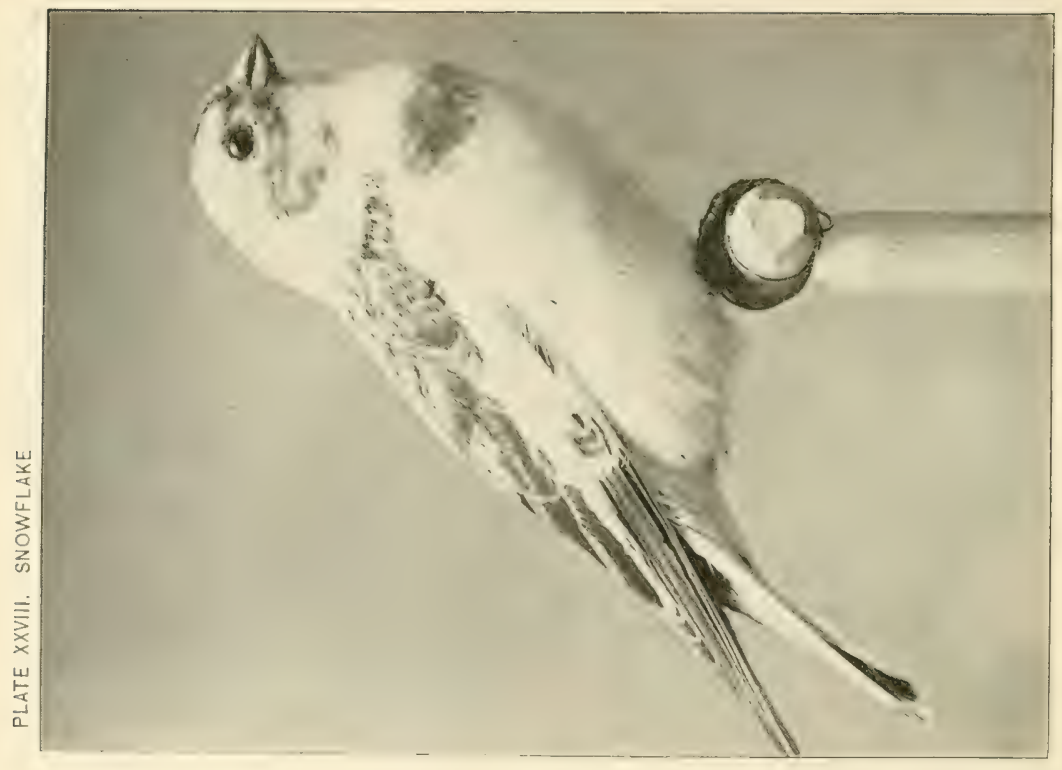




\section{PIATE XXVIII. SNOW'HLAKE SNOW BLINTINE:}

Piectrophenax nivalis.

In full plumage the middle of the lakk, the two immermost tailfeathers and the ends of some of the wme-feathers back: all else white.

In its Winter plomage, as it is seen here, the white, particularly on the head, is tinged with reddish-hrown. and a hrown collar almost completely encircles the neck. Bill light: leas dark. Length. 0.40 inches.

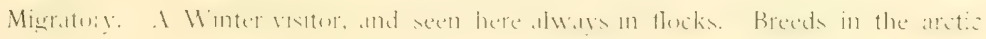
regions.

\section{FIELD SPARROW.}

\section{Spizella pusilla.}

Crown chestnut : hack streaked with dull red, llack and dull white: cheeks, throat and hreast pale hown: helly white: al light line over the eye: wings and tail bromm. many of the feathers pale-edged-the 
PLATE $X X I X$. VESPER SPARROW.

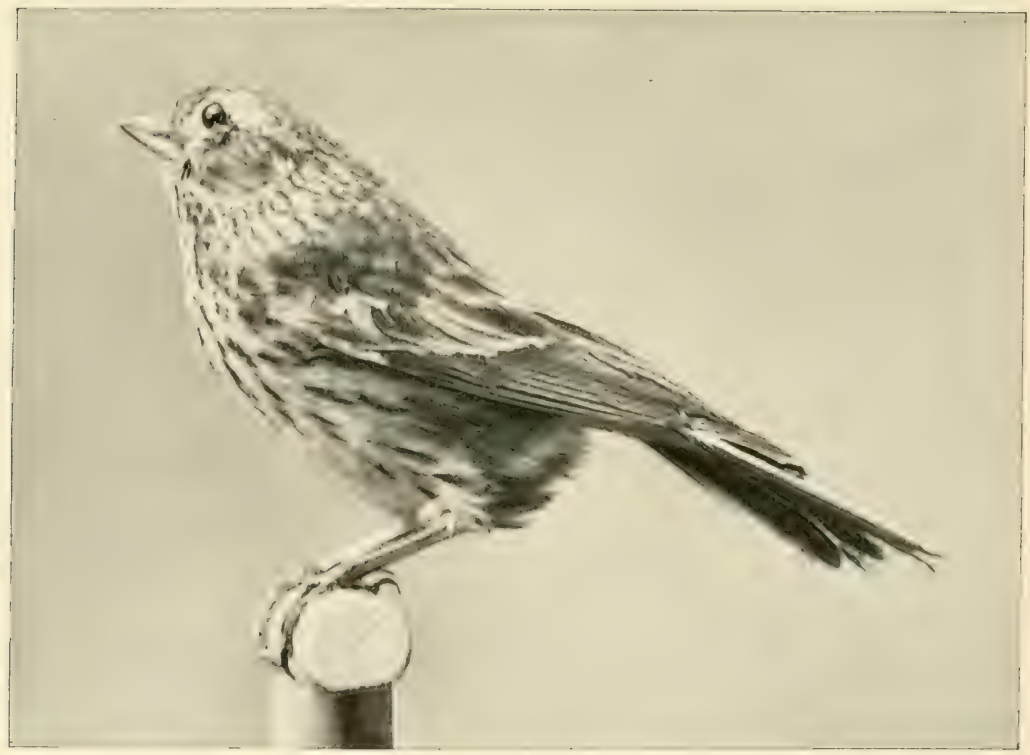


wings with two light bands: hill pale red: feet light. I.ength, a.0 = inches.

Minratory. Arrives late in April and is seen in flocks inholhiting the open fields and road-sides. In May it pairs and huilds a nest which is placed sometimes in low bushes and sometimes upon the ground. At this seasen its simple somer is heard, al warble of little variety. Int uttered by the male bird with commendable viger and persistency, als. perched upon a stump or low branch desse log, he watches over his

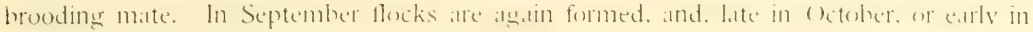
November, all depart.

\section{PLATE XXIX.-VESPER SPARROW: BAY-WIN( GRASS FINCH.}

\section{Poocates gramineus.}

Above light brown streaked with darker: beneath yellowishwhite streaked on hreast and sides with hrown: wings light brown, readish on the shoulders, and with two palte bands : tail slightly motched, 
PLATE XXX. WHITE.THROATED SPARROW.

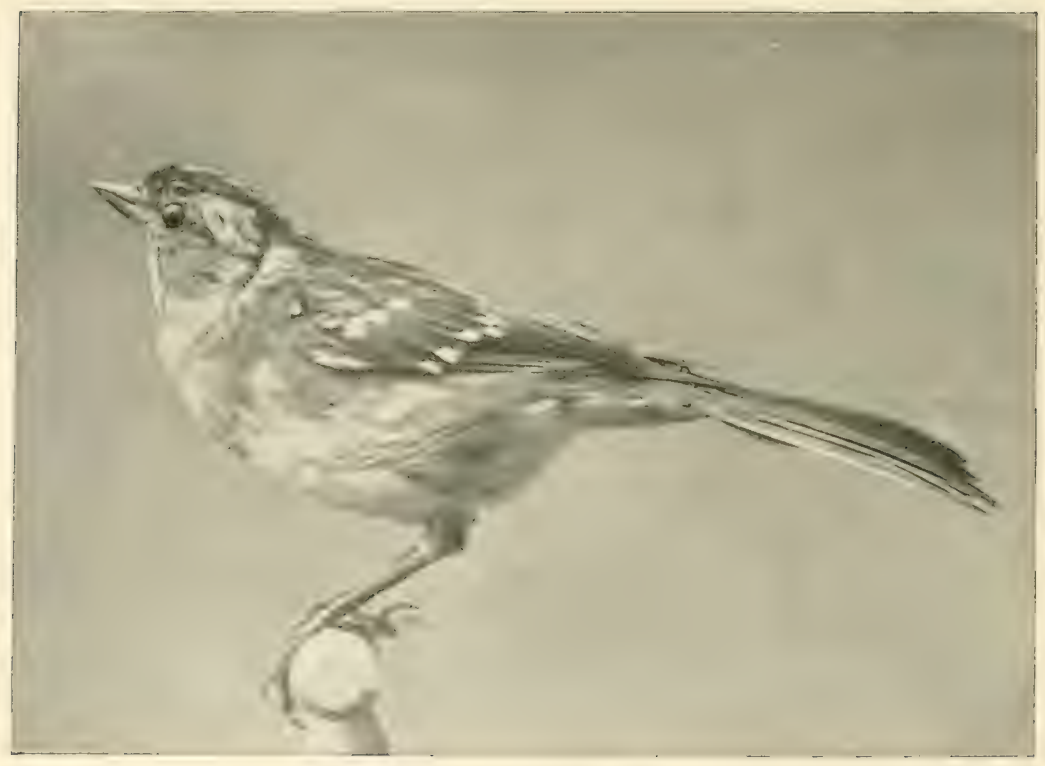


the outermost feathers almost entirely white: hill and leet pale. Length. 6. 10 inches.

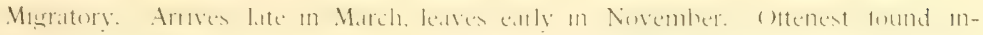

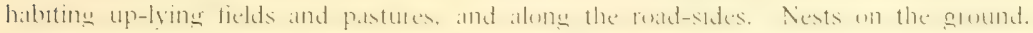

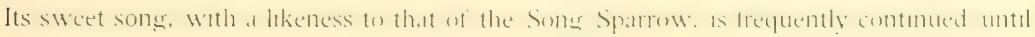
after sunset, whence the pretty name Vesper Sparrow.

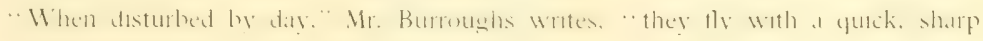
movement, showing the two white quills in the tail."

PLATE XXX.-WHITE-THR(ATEI) SPARROW. PEABODY BIRI).

\section{Zonotrichia albicollis.}

Heald with one central white stripe, then two hlact ones, and then two stripes which are yellow from bill to eye and white heyond: cheeks dark ash bordered with hiak: chin whik: brealst dark ash shading to white on the belly: rack strealied with blake reddish-bomatr and pale yellow: rump ash: wings reddish-hromm. with two transierse white 
bands; tail reddish-brown, slightly rounded; bill dark, feet lighter. Length, 6.75 inches.

Migratory. Abundant during the migratory periods, that is, in Spring, from the 2oth of April to the 20 th of May : and again, in Autumn, from the latter part of September to the middle of November. Through the Summer this Sparrow is not found here; in Winter occasional stragrglers are seen. Thoreau, in his Malns. Woms. mentions the song of the White-throated Sparrow as being the hird-note constantly heard hy him upon three excursions into the northern part of the state. These excursions were made in Summer. and the plices visited were undoubtediy favorite breeding resorts of the bird.

The nest is said to he built upon the ground, and, during its occupancy, the birds pair; but, when the young have flown, they assemble in small flocks and haunt the thickets.

The song, though an agreable one, is not free from monotony. It has been rendered ce-e-peabody, and its syllabic suggrestions are answerable for one of the bird's popular names. 


\section{GRASSHOPPFR SPARROW. YELLOW-WINCED SPARROW. YELLOW-WINGED BUNTING.}

\section{Ammodramus savannarum passerinus.}

Crown black with a central yellowish stripe: back streaked and spotted with black, brown, red and dull white: a light stripe over the eye: breast pale drab, lighter in the centre: belly soiled white: wings dusky, the shoulders wat with yellow; tail dusky, the outer feathers wholly lighter than the inner ones, notched: the feathers of hoth tail and wings more or less edged with paler: bill stout, short, rather pale : feet pale. Length, 5.35 inches.

Migratory. Arrives early in May. leaves early in Oetoler. Nests on the ground. A frequent but shy and unobtrusive little creature. As you ramble through the fields you will hear his " peculiar. chirring note." and probably will suppose it to he made hy some insect: for the sound is very similar to that produced by the grasshopper. It is because of this note that the name Grasshopper Sparow has been given.

Ploceding on your way, you may chance to catch a glimpse of a small hird flitting . 
PI ATE XXXI CHIFPING SPARROW

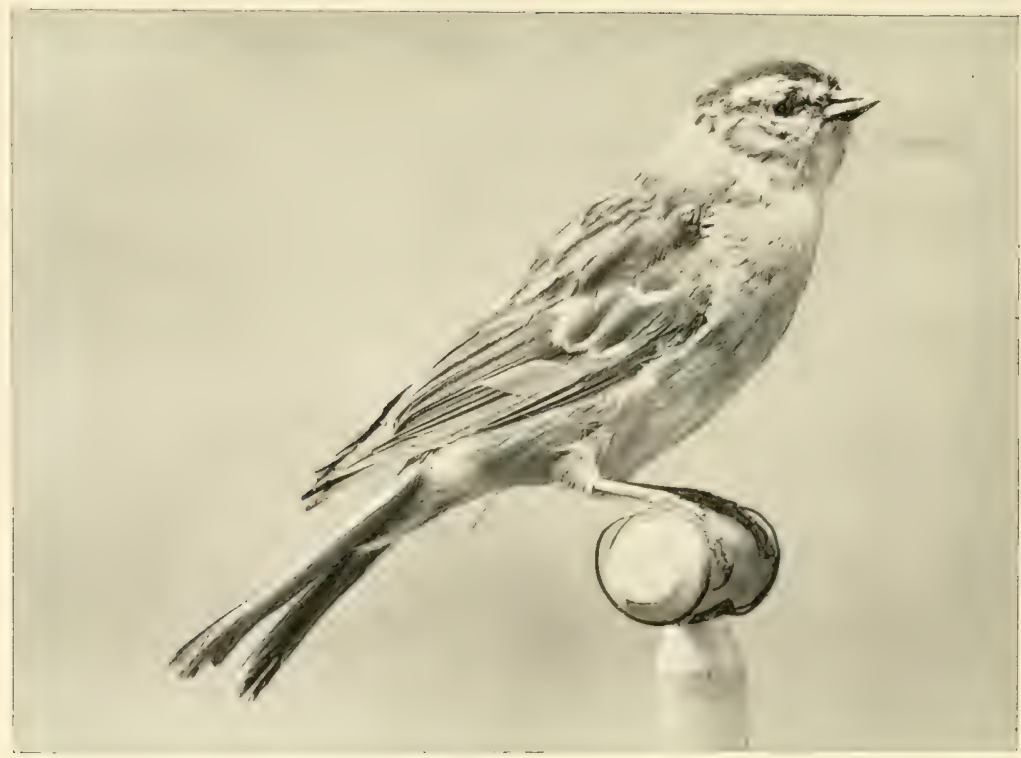




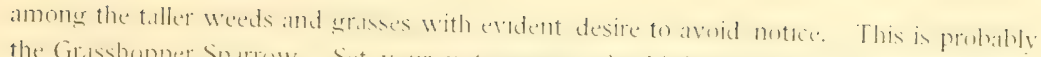

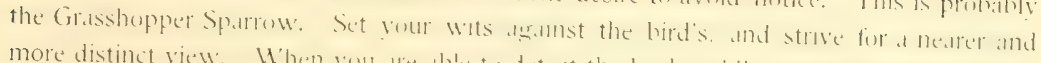

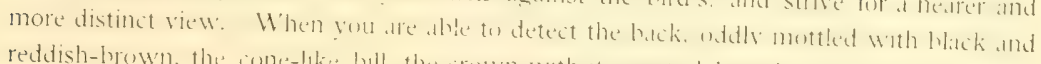

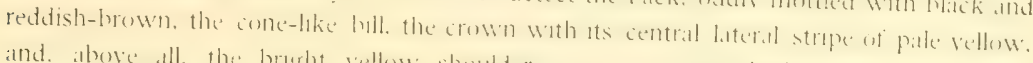

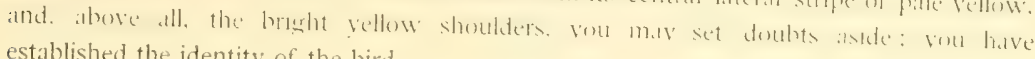
established the identity of the bird.

\section{PLATE XXXI-C.HIPPIN(; SPARROW: CHIPIYY. HAIR-BIRI).}

\section{Spizella socialis.}

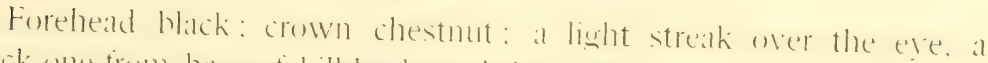
black one from hase of hill backuard through the ele : moler-parts and

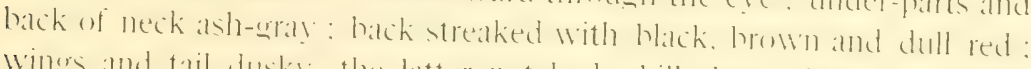
wings and tail dusk! the latter motihed: bill short. dirk: leas pale. Length, 5.35 inches.

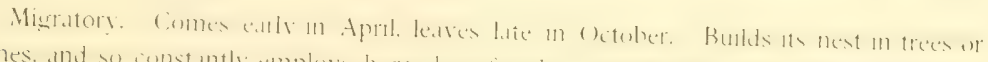

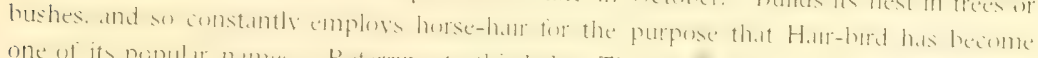

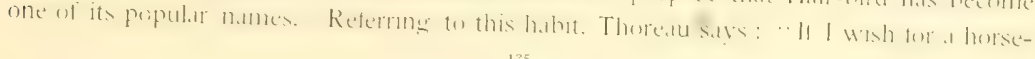


PLATE XXXII. JUNCO.

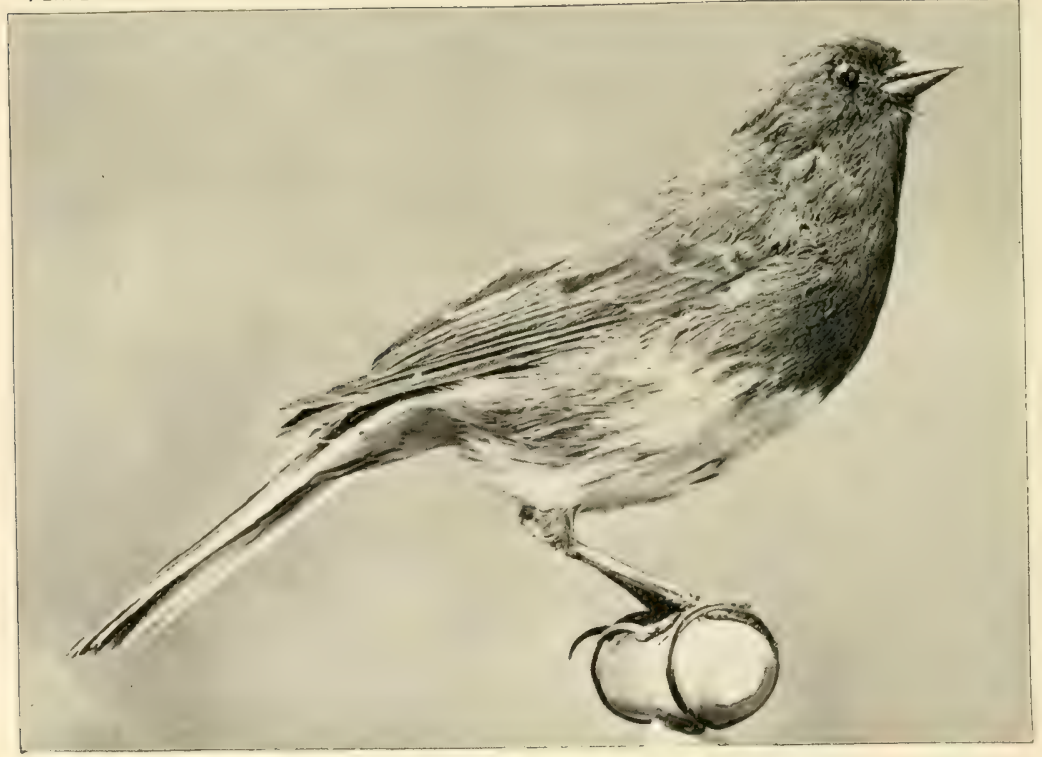


hair for my compass-sight, I must go to the stable : but the Hair-bird, with her shatp eves. goes to the road."

Chippy is motally a hird fond of man s society : at least he finds in the neighhorhond of gardens, human habitations and domestic animals the shelter. food and building materials best suited to his wants.

He is one of the tirst of the birds to comes and among the list to go, and his constant

presence about the door-vard in the gatrden lends more of homeliness and comfort to rural dwellings than he is apt to gain credit for. His note is a trill of considerable duration. suggestive of the sound of the cicadil: ertanly not a beatiful some. hut beciuse of familiarity and association. one whose loss woruld he deplored.

\section{PLATE XXXII.-SIAATE-COLORED IUNCO. IUNCO. SNOWBIRD.}

\section{Junco byemalis.}

Head, neck and back slaty-black, darkest on the head: wings and tail dark brown, the latter nearly even and with white outside feathers: bill and legs dark. Length, 0.25 inches.

Migaltory. Common through the winter months, coming from the north late in 
PLATE XXXIII. SONG SPARROW.

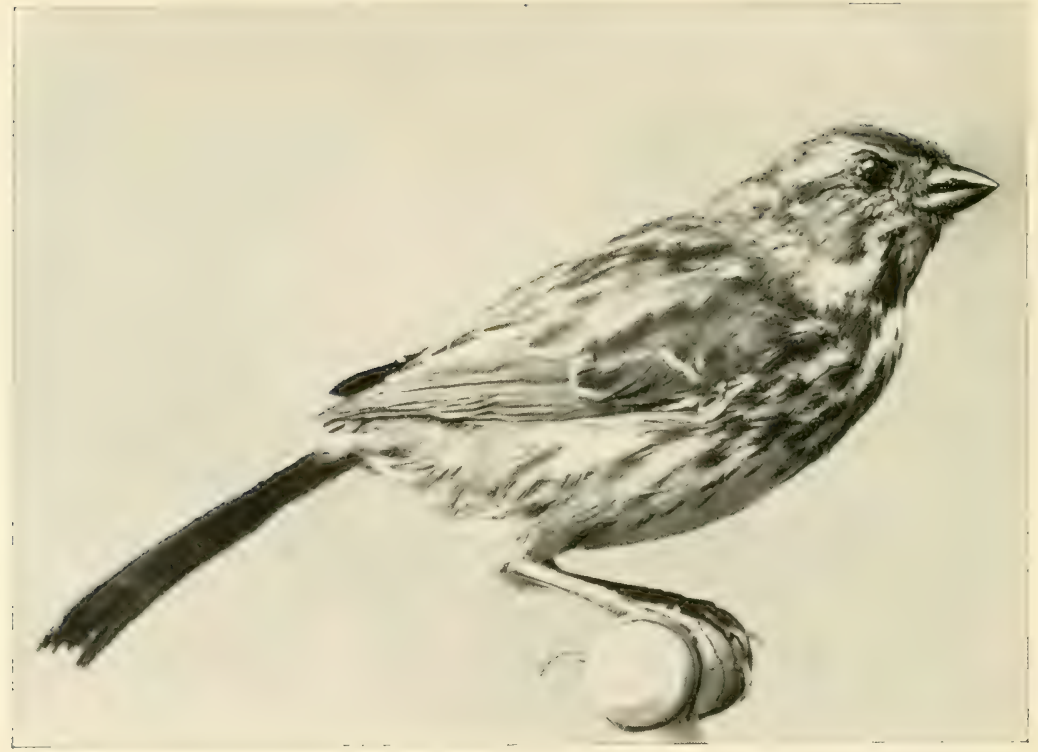




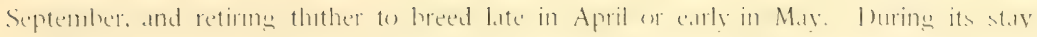

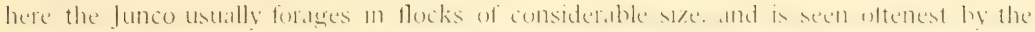

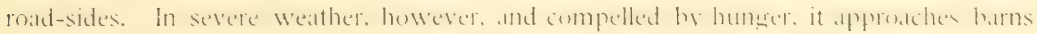
and dwellings, and. litying aside its customary tmidaty. hecomes quate fealless.

Its song is not much more than a high-pitched trill and is not often heard.

probably the bird is more voluble in its nothern mesting-places, laig anly an spring. just upon the eve of its departure. do we detect the sunge and we mily reasonaluly suppose that what we catch is hut the preparatury tuming up, so to sals a sort of making ready for the real nuptial chant. It has a call, while with us, which l)r. Cones tems * its snapping note."

\section{PLATE XXXIII.SSONG, SPARROW.}

Melospiąa fasciata.

Above streaked with black and hrown: crown chestnut with small hlack stripes: under-parts white streaked with black and hrown: a brown stripe behind the eye: wing feathers edged with dull red: tail 


\section{PLATE XXXIV. FOX SPARROW.}

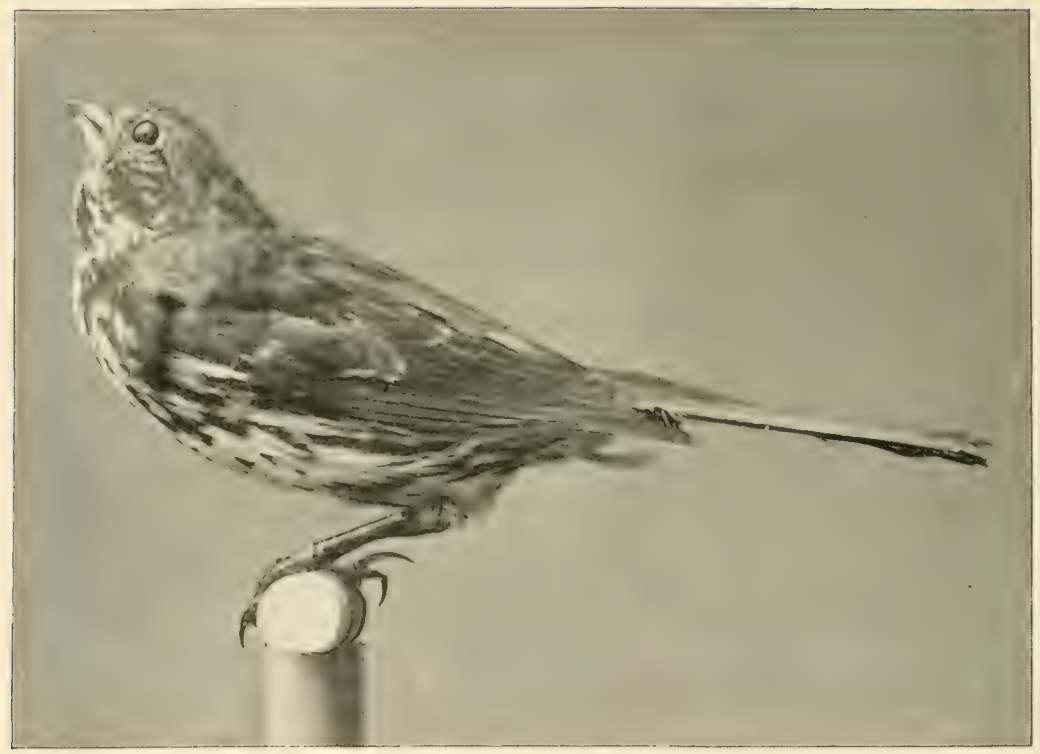


brown. long and nearly even: hill and feet pale hrown. Length, 6.30 inches.

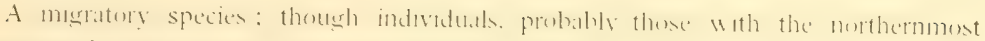

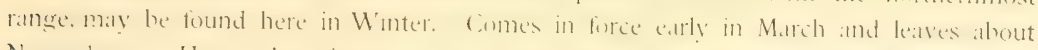
November 1. Has a chamming somer one high note thrice repeated. then a canary-like cadenzat. This is perhaps the most moticeable songe heard in fiededs and horders of woods.

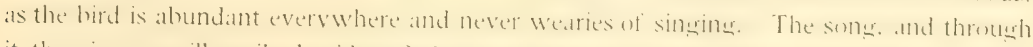

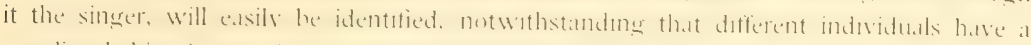

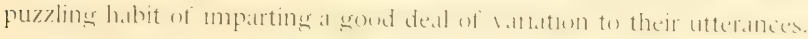

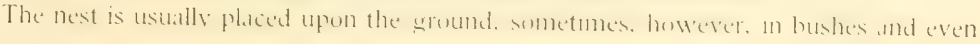
in low trees.

\section{PLATE XXXIV.-FOX SPARROW.}

\section{Passerella iliaca.}

Above ash streaked with reddish-hrown : helow white thickly spotted and dished with reddish-hrown, except on the helly which is un- 


\section{PLATE XXXV. CHEWINK.}

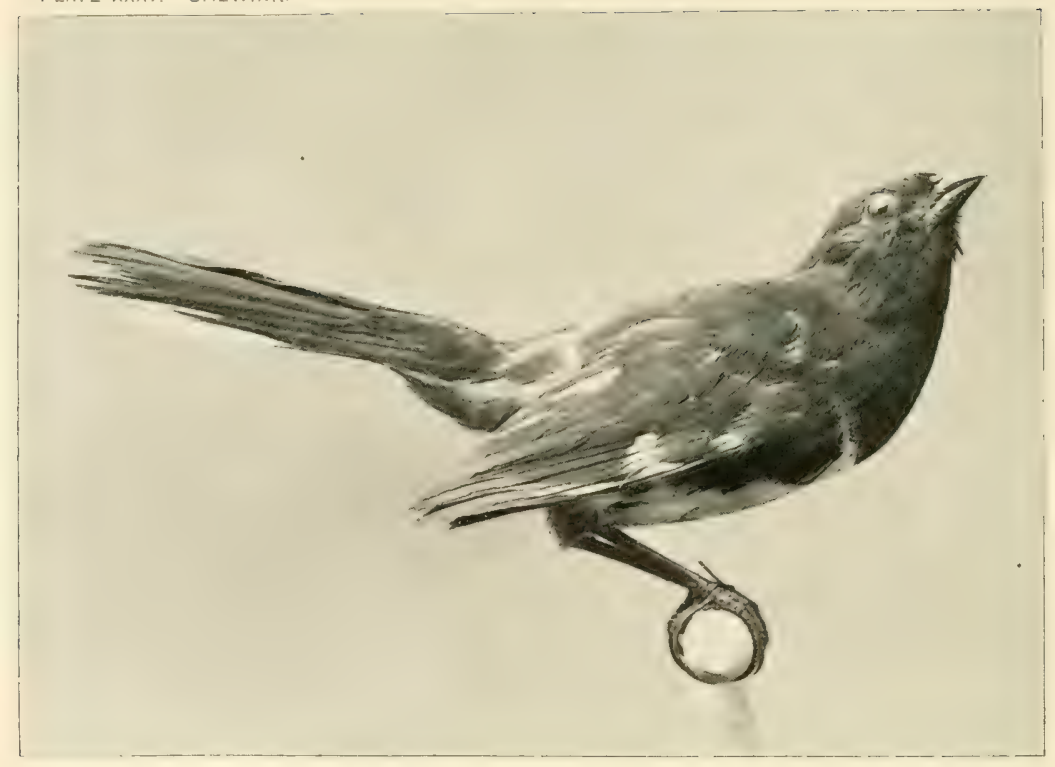


marked: wings and tail bright rufous, the former with two light bands.

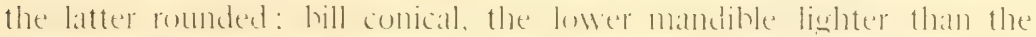
upper one: feet pale. Length, 7.25 inches.

Migritury: Comes enty in March. remams until the middle of April. then passes to

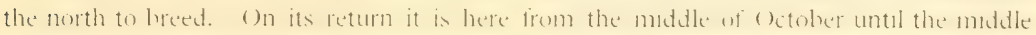
of November. When it leaves wor the suth. The Fox Spamow is the laresest and hamdsomest of the sparrouss and is alse a fine smeer. No difficultr need be apprehemded

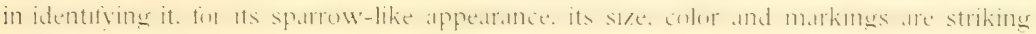
and unmistakable.

\section{PLATE XXXV. -TOWHEE. CHEWINK.}

\section{Pipilo erytbropbtbalmus.}

Upper-parts, head, neck and upper-breast black: lower-breast and midalle of belly white: sides dhestmut: wings black with white bands 


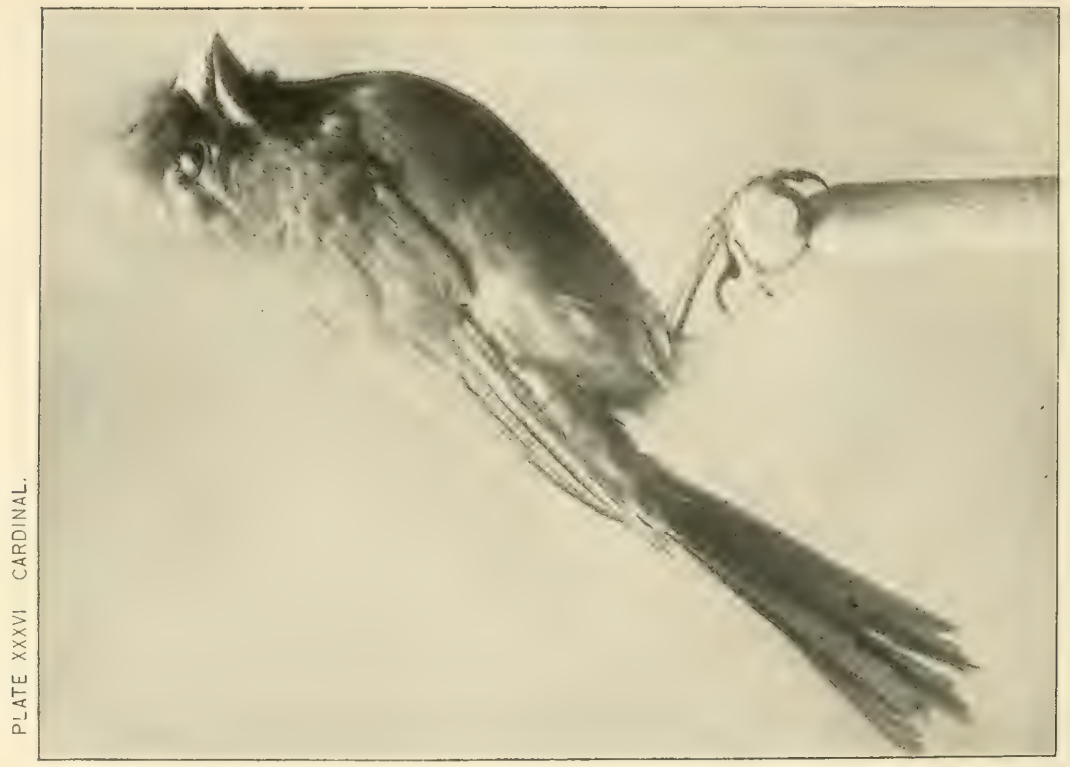


and spots: tail rounded, black, the onter feathers patched with white: bill black: legs brown. Length. 8.35 inches.

Migratory. Arrives middle of April. deaves late in (betoher. Nests on the ground.

Its notes, chewink and towher, sugerest its populat mames.

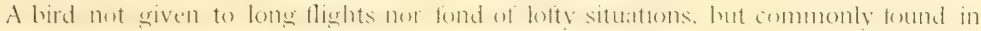
thickets of upon the ground scrotching amomes the leatves.

\section{PIATH XXXVI.-CARIDINAI. GR(OSBEAK. CARDINAL. \\ Cardinalis cardinalis.}

Prevailing colen red, darker on balck: splendidly crested : fice and throat hlack: upper surface of wings and tail uratsish, the latter long and nearly square: bill light, tinged with red: beet brown. Length, 8.40 inches.

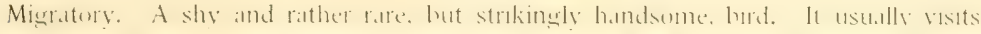
us only during the hottest months. and seldom nests so far morth as au latutude. Dr. 


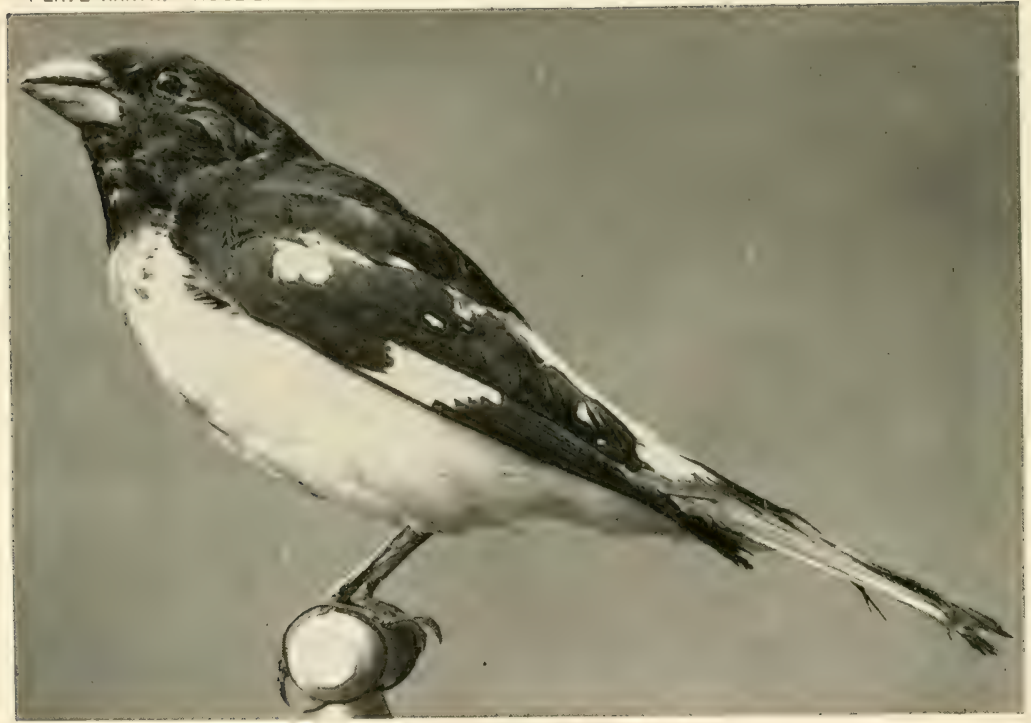


Allen informs me. however. that a small colong has been for some gears resident in Central Park. New York City, remaining in W'inter and nesting there in Summer.

Dr. Coues describes the Cardinal's notes as "rich. rolling. whistling."

\section{PLATE XXXVII. ROSE-BREASTEI) (GROSBEAK.}

\section{Habia lndoviciana.}

Heat, neck, throat and back hack: helly and rump white: hreast and lining of wings rose-red: wings and tail black, the former with two white bands, the latter notched, and patched with white: bill large, conical, light: feet dark. length. S. 10 inches.

Migratorv. Arrives early in Mav. leaves late in September. Nests in hushes and low trees. Sons. " a sweet warble with vartous emphatic passigres, and sometimes a plaintive strain, exceedingly tender and affecting."

A beiutiful but rather rale bird: and the day upon which its acquantame 1 made may be justly regarded as a most fortunate one. 
PLATE $X X X V I I I$. SUMMER TANAGER.

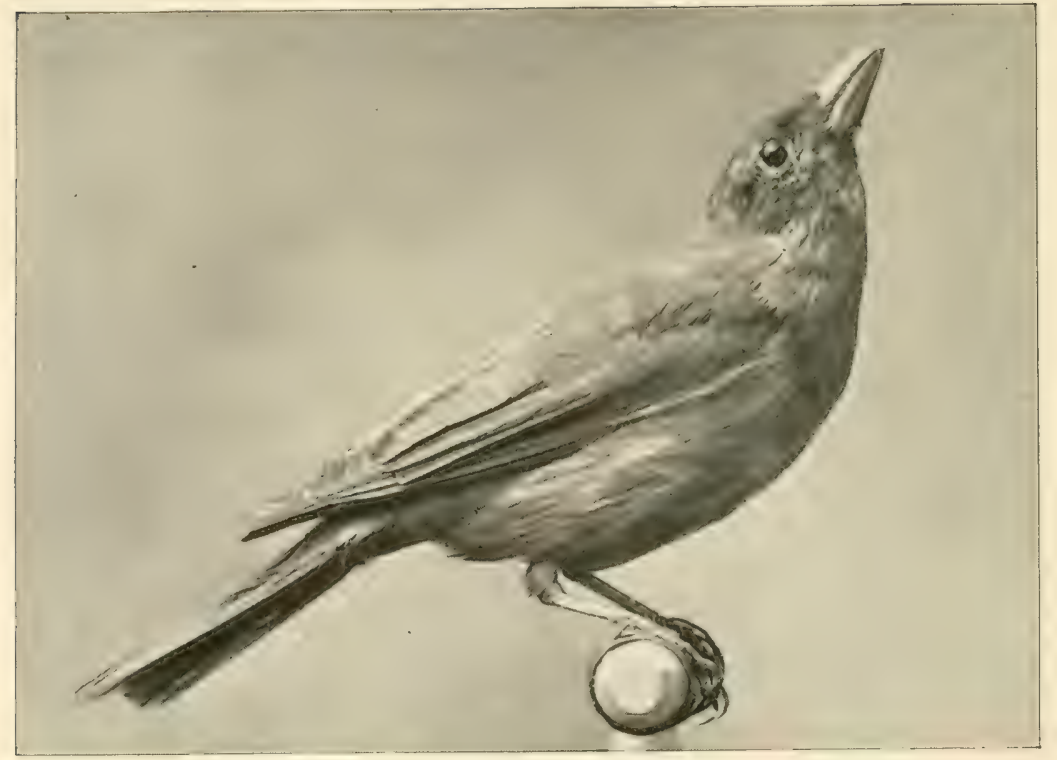




\section{INI)I(i) BUNTING, INI)I(;)-BIRI).}

\section{Passerina cranea.}

Blue all over: wings and tail darter than the hody: lower mandible paler than the upper one: tail nearly even: less dark. Length. 5.5\% inches.

Migratory. Arrives late in Mave katves midalle of September. Nests in hushes. A

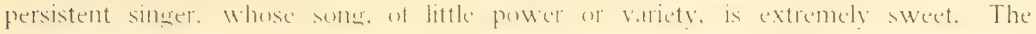

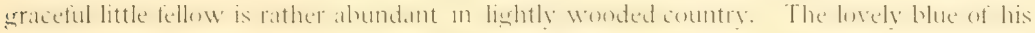

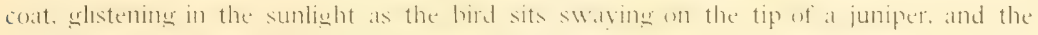

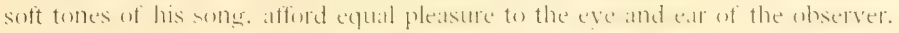

PIATE XXXVIII.-SUMMER TANAGER, SUMMER REIBBIRD.

Piranga rubra.

Red all over, including wings and tail, the red of the wings less 
hrilliant than elsewhere: tail symare: hill light : legs darker. Length. 7.50 inches.

Migraters. Not a frequent visiter here. though seen oftener some seasons than others, this regrion being probally about the morthernmost limit of jts range. It is not so rare a hird, however, that it may not be sought with full confidence of ultimate suciess.

Like all of the Tanager family. it is an unmusical but handsome bird.

\section{SCARLET TANAGER.}

Piranga erythromelas.

Generall color scilrlet: wings and tail lack, the latter nearly even : bill pale, legs darker. Length, 7.25 inches.

Minrattory. Arrives middle of Maly. leaves early in ()ctoluer. Nests in trees in woods or orchards. Its song has been thought to resemble that of the Robin. and indeed there is a likeness between the two: the Robin's excelling, however. in heartiness if not in variety.

The scarlet Tannager is a bird of gorgeous appearance, and is a conspicuous adornment of the groves which it inhabits. 


\section{PLATE XXXIX. - BARN SWALLOW.}

\section{Cbelidon erytbrogaster.}

Ahove steel blue: throat deep chestmut : helly light chestnut : a blue band across the healst: forehead chestnut: wings and tail black and long, the latter deeply forked and spotted with white : hill black: legs purple. Length, 6.95 inches.

Migratory. Arrives late in Aprol. leaves carly in September. Its next at mud and straw is attached to rafters and eaves of houses or barns.

The wonderfully agrile and araceful thight of this hird is mate the theme of $\mathrm{Mr}$. Ruskin's fascmatme essay. Low s Mow. Which will allord the keenest enjoyment to all bird-lovers.

Mach discussion has prevalled as to whether the Barn Swallow migrates or hibemates. More tham a century ago Gilbert White was lull of specubation regarding it, ats mamy pages of his Natural. History of Selborne show.

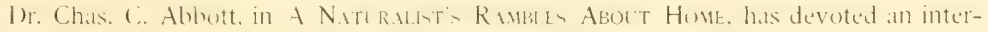
esting chapter to the subject : and. indeed. writers on birds have all found the theme al 
PLATE $X X X I X$. BARN SWALLOW.

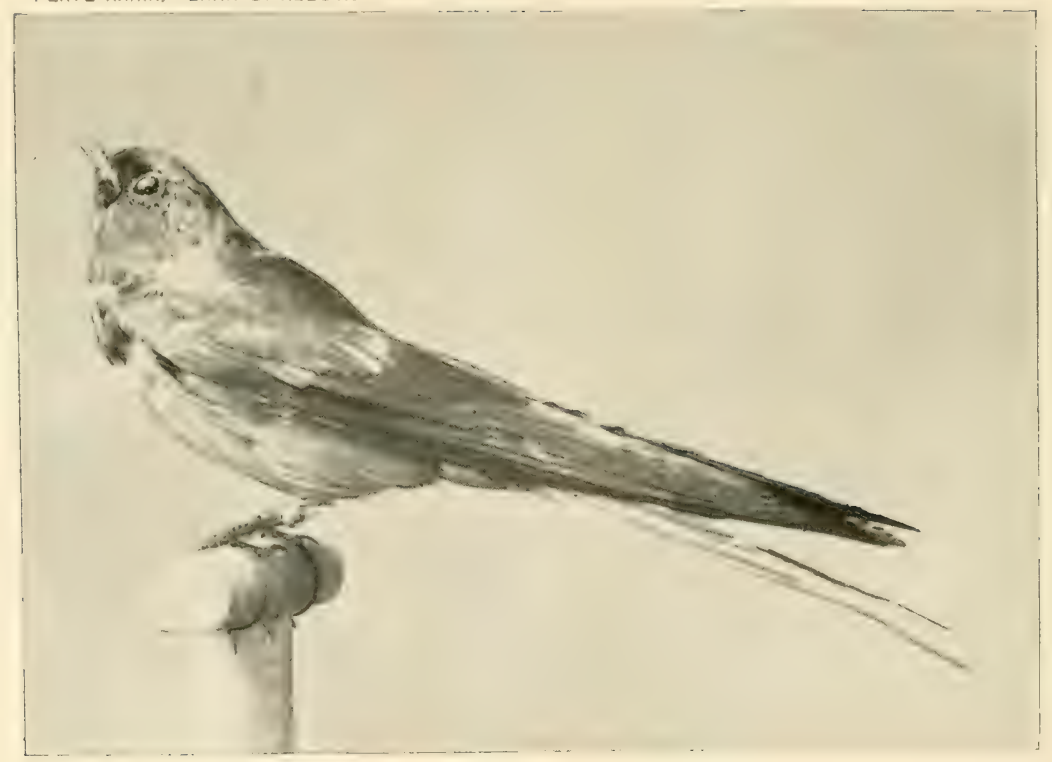




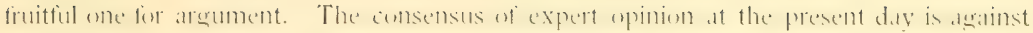

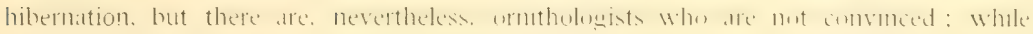

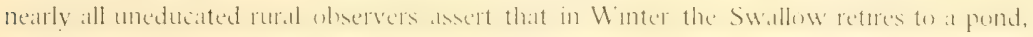
where sinking inte its depths. He rolls himself in a mud cisinger or shell, and in a state of torpidity, awaits the coming of Spring.

It is strange that such a curiug heliet. unsupponted by evidences should take possession of men's muds : hut the convetum of hibemation in this manner on the part

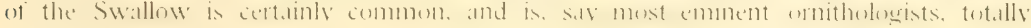
unsubstantiated by proof.

Mi. Bicknell cills the song of the Bam Swallow $\cdots$, how. chattering trill * * often terminating with a clear, liquid note $*$ not unlike one of the notes of a Canary." 
PLATE XL BANK SWALLOW.

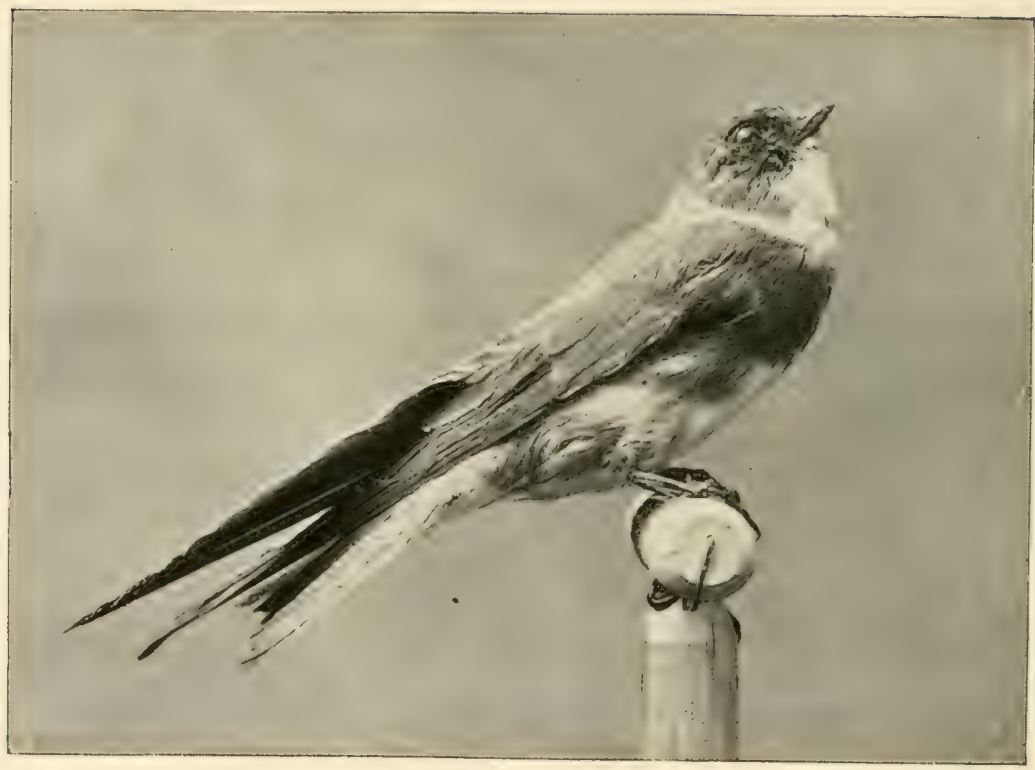




\section{PLATE XL--BANK SWALLOW.}

\section{Clivicola riparia.}

Ahove gray-brown: beneath white, with a hrown band aldoss the breast: wings and tail darker than hody (the tail nearly syuares : hill dark: teet lighter. I.ength, a.20 inches.

Migratory. Arrives ahout May 20, Leaves 11 September. The Bank Sirallew is

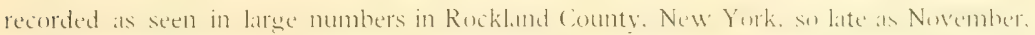
but this is exceptional. Its nest is plated in a hole exiavaled an a sand-bank. Laver in colonies. Note soft and lisping. 


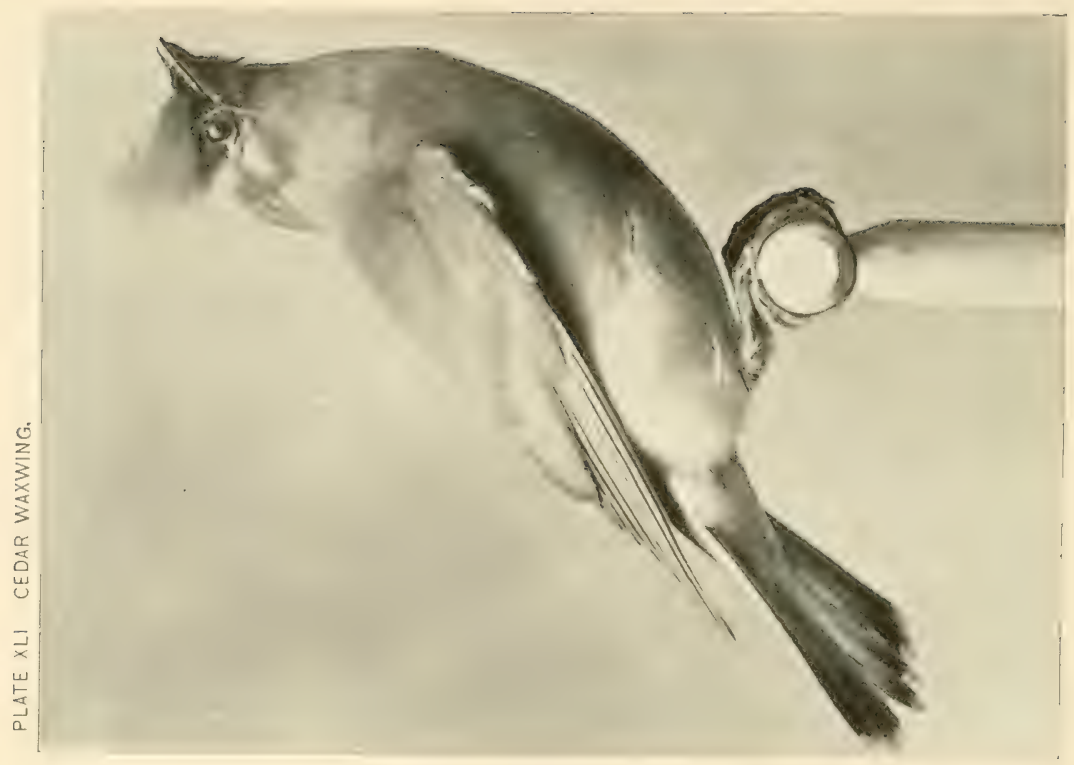




\section{PLATE XII.-CEDAR WAXWIN(3. (EI)ARBIRI).}

Ampelis cedrorum.

Head orested: forehead and sides of head hatk, indistinctly hordered with white : a small white streak under the ere, and a larger one on the lower cheek commencing under the hase of the hill : rest and back of head cinnamon, shatding lighter alonge the hack to the rump where it is ash: chin blak shading inte cimnamenn on hreast, that inte yellow on belly, and that into white under the tail: wings dark with red: hormy tips on some of the yuills: tail dark, syluare. With a yellow terminal hand and (sometimes) with red, hom tips: hill and lews dark. Length, 7.15 inches.

". It wanders about." says 1)r. (onus. " acoording to foud supply : winters m most

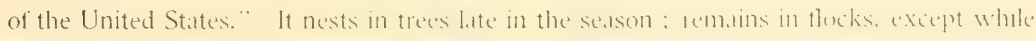
breeding. Its note is a feeble peep. 
PLATE XLII. NORTHEFN SHRIKE

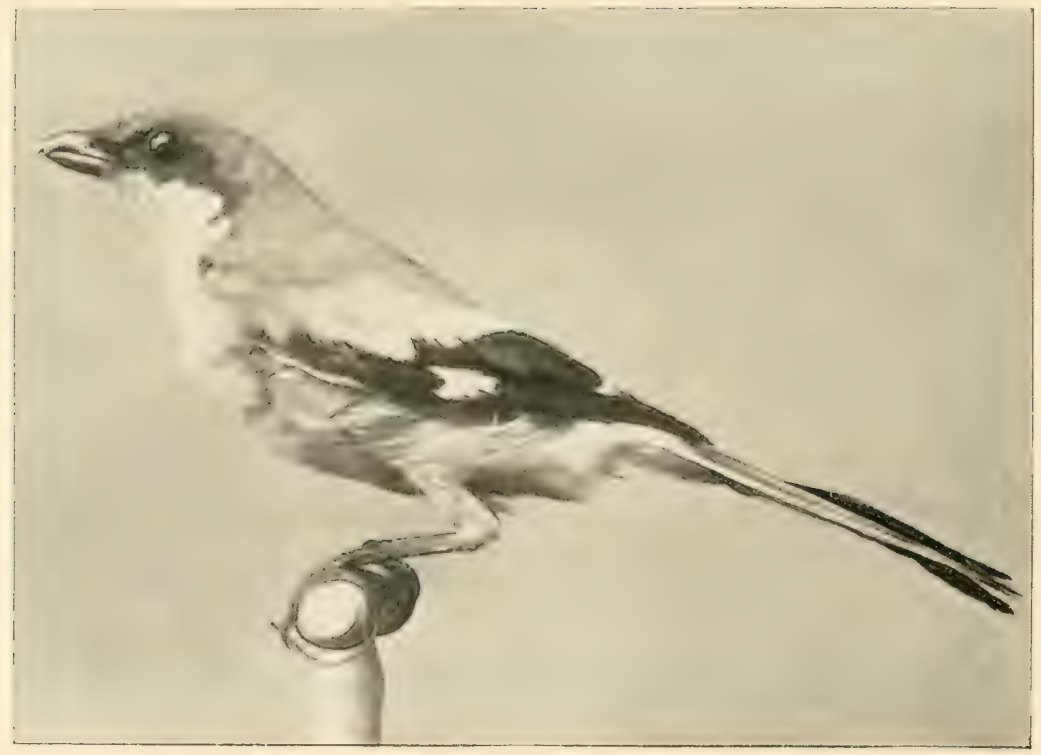




\section{PIATE XIII. NORTHERN SHRIKE: BUTCHIR-BIRL.}

\section{Lanius borealis.}

Above light bluish-graty shading to still lighter on the rumpl : benteath white, crossed with dark. wasy lines: sides of head houry white. with a black stripe passing through and behind the eye : wings and tall black. the former with a white patch and some white tippines. the latter moch rounded, and edged and hroakly tipped with white: bill and feet dark. Length, ro inches.

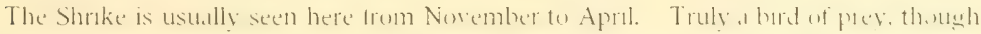
not clissed as such by ormthologists. Besides insects, it cipturess smoll burd and even amimals. which it devours. It hals a curious hatht. trom wheh it derrese ats name. Butcherbird, of impaling the creatures whech it has seized upon thoms. ws a huteher would hang up al carcass.

The observer who is fortunate enough to have wathessed the Shroke thus shughtering ats victim. has probally condemned the bird as a monster of nedelless aruelty. But in the 


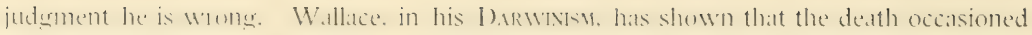
hy ereatures of prey is probaty a pandess one. Severall cines are cited to prove this : ambong them the well-known instance of Livingstone. Whe hous describes his sensations

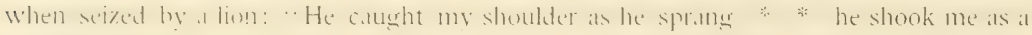
terrier-dus deses a rat. The shoik produced a stupor similar to that which secms to be felt

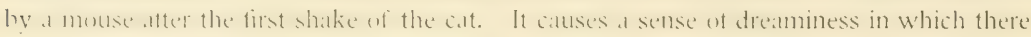

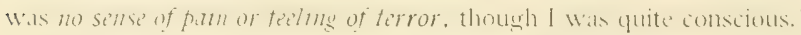

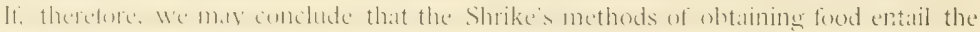

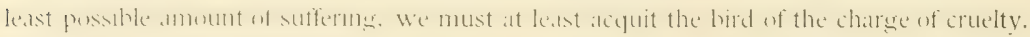

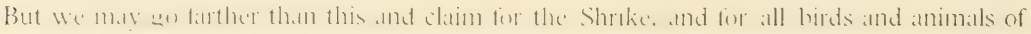

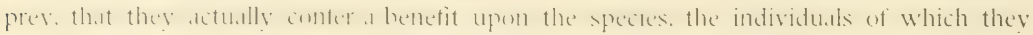

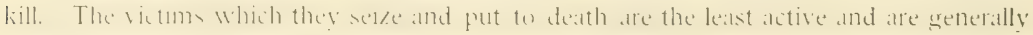
those wheh ale disciscd. The vigorous and healthy escome and since these perpetuate the nake, inckessed wiger and health in the offepring result.

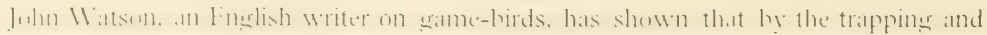

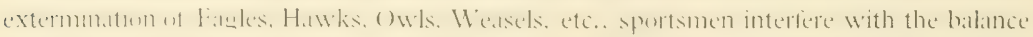

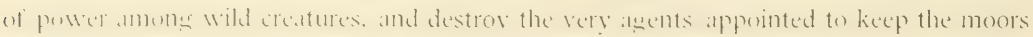

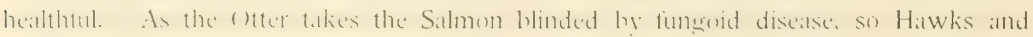
the like copture the slowest of the Grouse. Now the slowest Grouse is such be reison of 


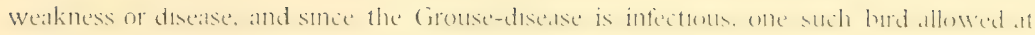
large may taint a whole covey.

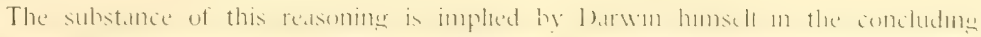

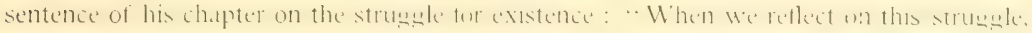

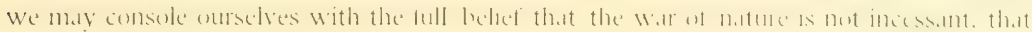

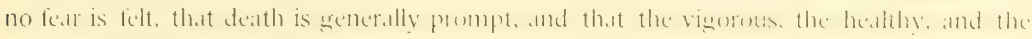
happy survive and multiply."

\section{YEIILOW-THROATEI) VIRE(). YEIIOW-THR()ATFI) GREENLET.}

\section{Vireo flavifions.}

Ahore olive-green, brightest on the head and shading to blue-eray on the rump: sides of neck and of breast olde-ereen: throat and centre

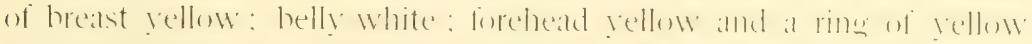
encircling the ege: wings brown with two white bands, and mant of 


\section{PLATE XLII REDEYED VIREO.}

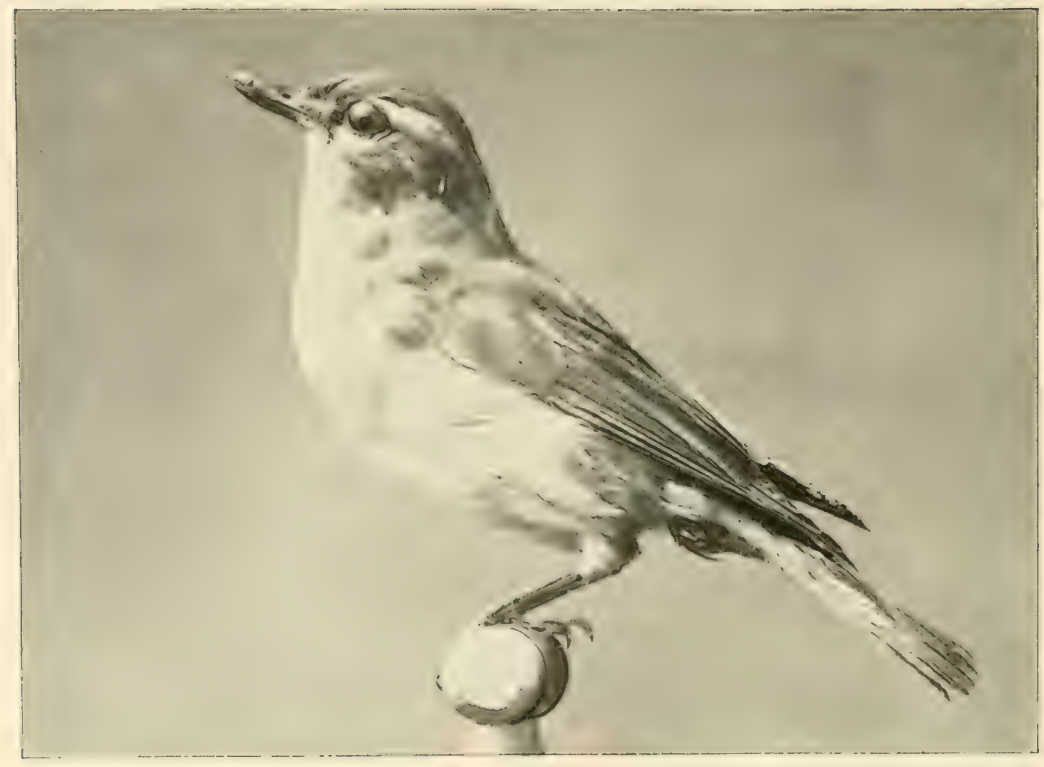


the feathers light-edsed: tail short, syuare, brown, many of the guills light-edged: bill and feet leat-color. Length, 5.9) inches.

Migratory. Arrives early in May. leaves late in September. Nests rather low in trees. chierly in woods ur orchards. A heiutiful bird and an aciomplished vocalist.

\section{PLATE XLIII.-RED-EYED VIREO. RED-EYED) (IREENLET.}

Vireo olivaceus.

Above light olive-green: crown ash edged with darker : a white streak passes throm and heyond the eye : cheeks pale wreen: throat and breast yellowish: belly white tinged on sides with yellow, and terminating under the rump in light yellow: tail short. nearly even, brown, the quills edued with greenish : lower mandihle lighter than the upper one: wings long. in color like the tail: reet leat-color: e'les red. Length, 6.20 inches.

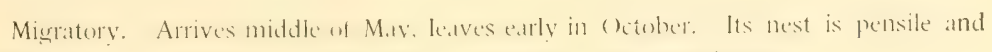
is attached to the bramih of a tree, usually in woods. A sweet singer. 
PLATE XLIV. SOLITARY VIREO.

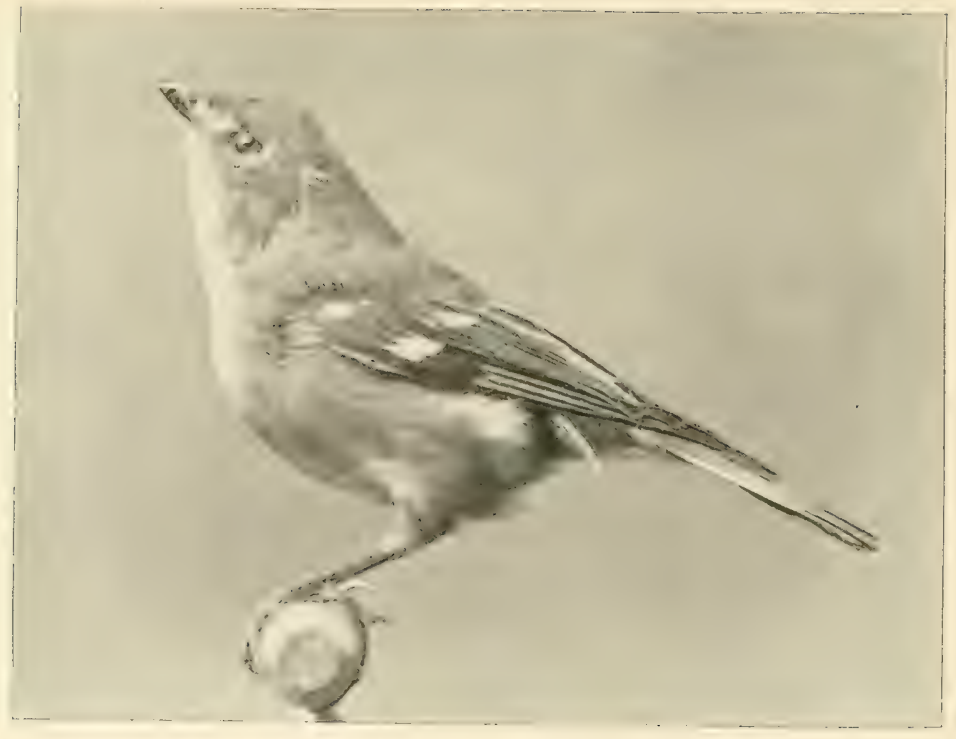




\section{PLATE XIIV.-BLUE-HEADED VIRE() (OR GRIENIET). S()LI- TARY VIREO (OR GREENLET.) \\ Vireo solitarins.}

Above olive-green: head and cheets blue gray : a white line from the nostrils to the eve and encircling it: breast pale ash: helly white: wings dark, with two white hars and many of the feathers edged with white: tail short. syuare. dirk, the outermost feathers edged with white: bill and feet dark. Length, 5.60 inches.

Migratory. Arrives carly in May, leaves carly in october. Nests in bushes or low trees. Like all of the Vireos, it is fearless and contiding towats man.

Bradfort Torrey relates an incident illustrative ut this docilits. He once found at Solitary s mest, the female sitting at the time upon her ewers, and was allowed to approach

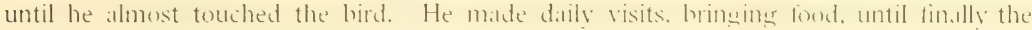
little creature hecame so tame as to eat insects and other daintes trom his hand, allowing him meanwhile gently to smooth her feathers.

The Solitary Vireo is not a rare bird though it is less commen than the Red-eyed, the 


\section{PLATE XLV. WHITE.EYED VIREO.}

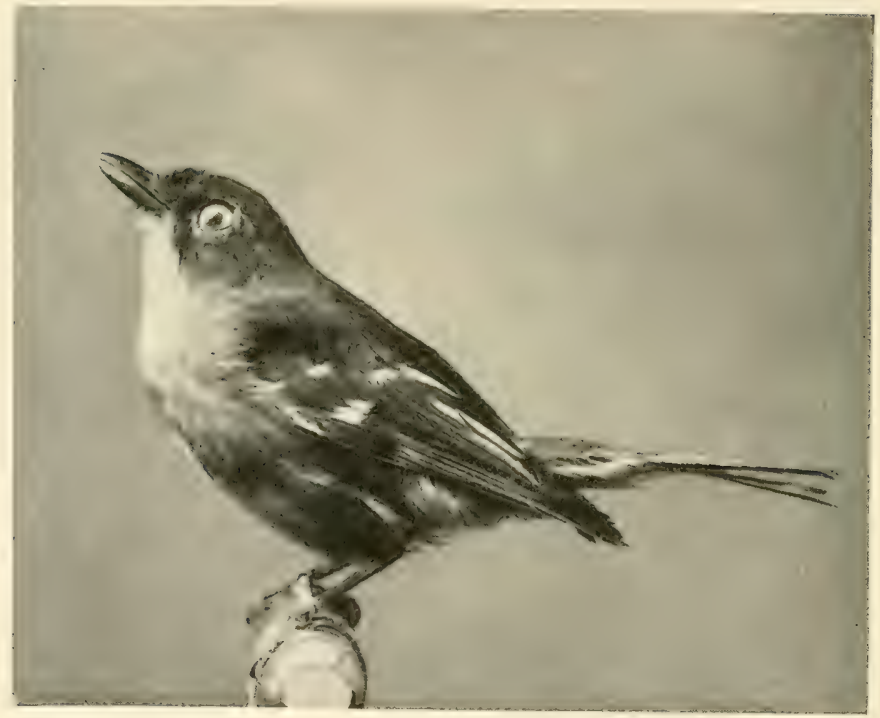


Yellow-throated of the White-ered. Probably the majorty of the species nest farther north than this locality ; for on their first arrival, about Maly 1 , and again, als they gro south in Septembet, they are quate numerous. While during the actual breeding seatson, they are less plentiful.

\section{PLATE XLV. -WHITE-FYED VIREO. WHITE-EYED GREENIFT.}

\section{Vireo noveboracensis.}

Above olive-green: a yellow line from the nostrils to the eye and encircling it: elo's abite: heast and belly dull white: sides of hody yellow: wings dusk!, with two light bands, some of the feathers lightedged: tail dusk!. nearly even: hill and teet dirk. l.ength, 5.25 inches.

Migratory. Arrives early in May. lewes the middle of october. Its nest is pensile and is usually placed in a bush. A sweet and persistent singer. 
PLATE XLVI. BLACK AND WHITE WARBLER.

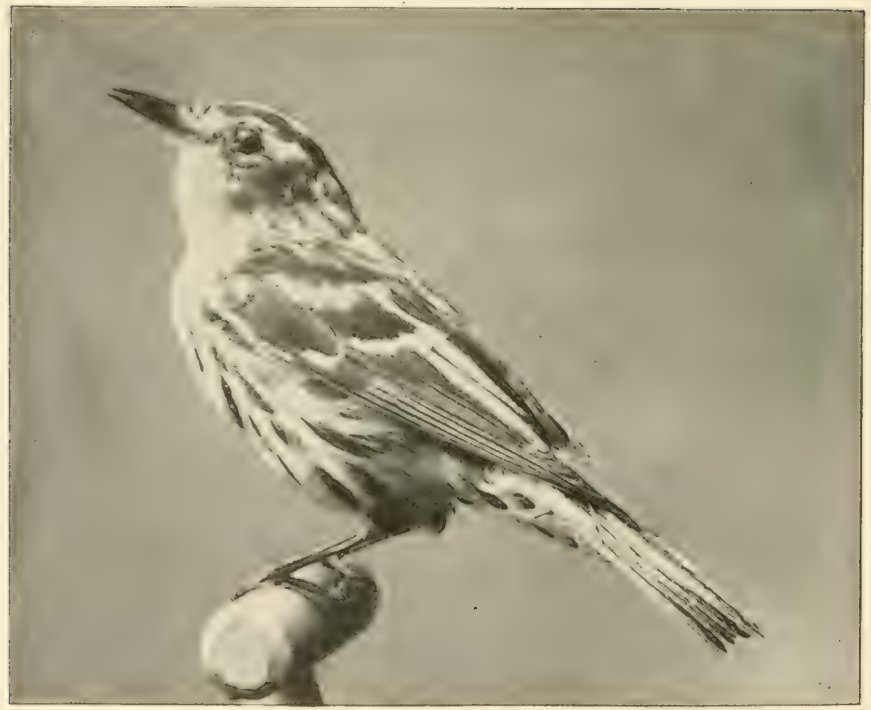




\section{PLATE XLVI.-BLACK ANI) WHITE WARBIIR. BLACK AND WHITE CREEPER.}

\section{Mniotilta varia.}

Black ahove, feathers much edged with white: white stripes on the crown, through the eye. and on the cheeks: helly white with black streaks on the sides: wings black. many of the leathers adged with white, and having two white, transierse hands: tail nearly even, lalck with some edging and spots of white: hill and feet dark. lemsth. 5.30 inches.

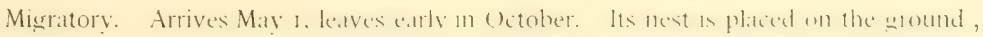
often near the root ol a stump or tree.

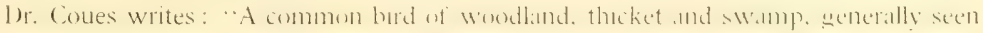
scrambling atively about the tranks and lafger bramihes w tress. rather like a Nuthatch than like a Creeper, the tail not being used as a prop."

A poor singer. 


\section{WORM-EATING WARBIER.}

\section{Helmitherus vermiverus.}

Ahove olive-ereen: heneath hull. paler alnost to whiteness on the belly: head all round huti with two blakk stripes on the crouvn extending from the bill to the nape, and a similat thomen narrower stripe thromgh the eve: wings and tail olive-green. the latter rometed: bill and feet pale. Length, 4.85 inches.

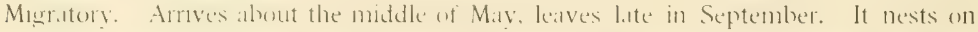

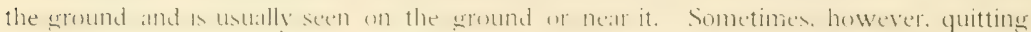

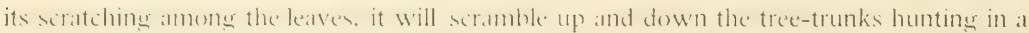
somewhat listles mamner lior insects and spiders. A she inative hird, not verv handsomes. a fechle singer and burdemed with a mame disigreeable in its sugegestions. 


\section{PARULA WARBLER. BLUE YELLOW-BACKED WARBLIR.}

\section{Compsotblypis americana.}

Above light-blue, with a patch of rellow in centre of the hack: chin and throat yellow: breast yellow, spotted with brown: helly doll white: wings bouvn. with two light hands, some of the feathers edged with blue: tail hrown, some of the feathers edged with hlese and the outer ones spotted near the tips with white: mpler mandible dark, lower one lighter: legs palte. Length, f.jo inches.

Migratory. Arrives midale of May. keaves carly in (citoluer. Nests m trees. It is not

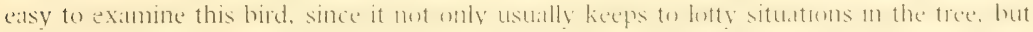

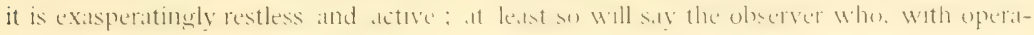

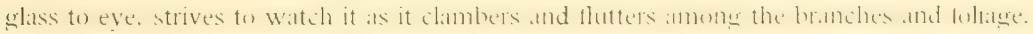

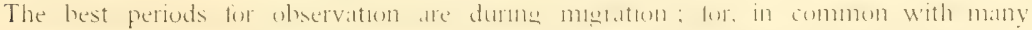

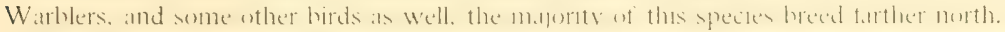

The bird student will not have prosecuted his researches ter a hong pertond without

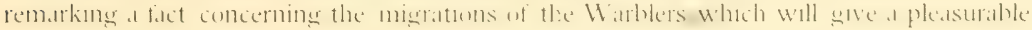




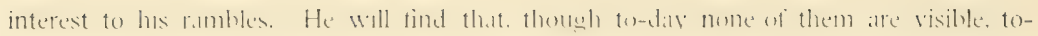

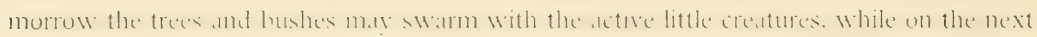

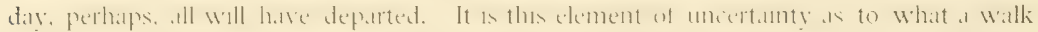

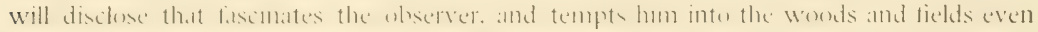
upon unpromismer d.19: and in the most inclement weather.

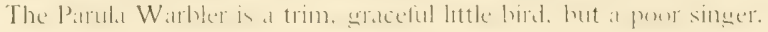

\section{YELI.()W' WARBLER. SUMMLR YELIOW'BIRD.}

\section{Dentroica arstiva.}

Above gresenish-yellow : cromm and moler-parts golden, streaked with rectelish-brown: wings and tail dusk! most of the feathers edged with

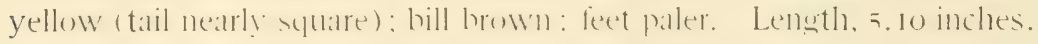

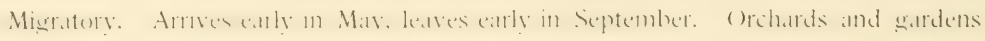
furnish the conditions it prefers for a nesting site.

Flight undulatory ; song pleasing but unimportant.

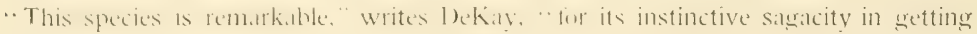




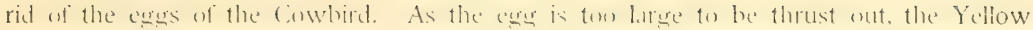

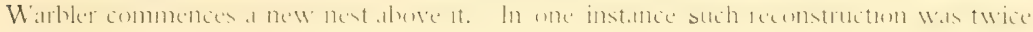
effected ; thus forming il nest of three stories."

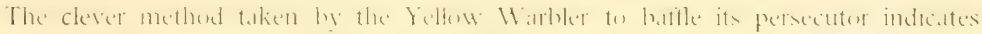

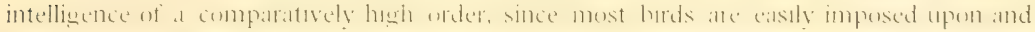

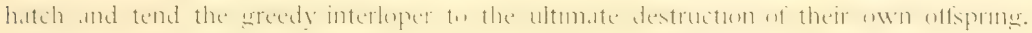

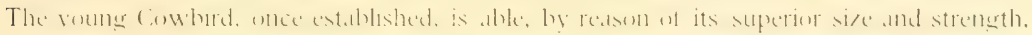

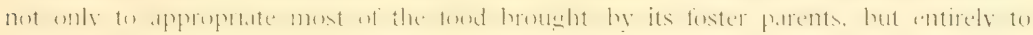
dispossoss its lucklus compumuns by crowding them out of the nest, when, falling to the ground, they perish miserably. 


\section{MYRTLE. WARBLFR. YFLI(IW-RUMPEI) WARBLER. MYRTLEBIRD.}

\section{Dendroica coronata.}

Ahove slats-hlue streaked with black: helow white, except the upper-breast and sides of holy which are black : irowe, rump and a spot

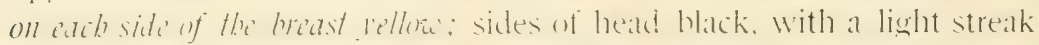

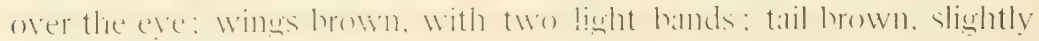
notched and somewhat spotted with white : hill and teet datk. Length. 5.65 inches.

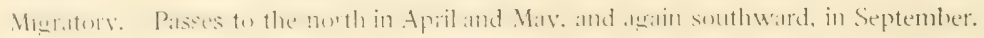
At these times, for shot periods, it is rather abundant.

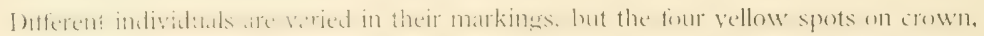

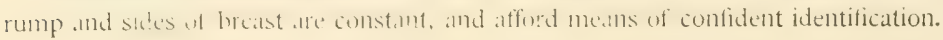




\section{BI.ACKBURNIAN WARBLER.}

\section{Dendroica blackburniat.}

Black ahove including wings and tail, but with an mange stripe on crown, a white patch on wings and a lisht strips: on hack: neck, upper breast, and sides of head, hright orallete-enept a blak streak through the eye widening from the bill hackwards (in this blak streak, moler the

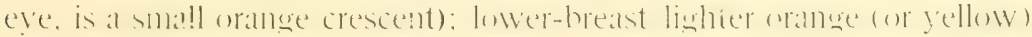

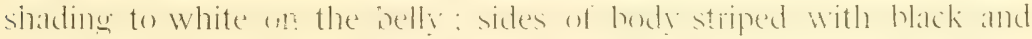
white: tail nearly even, with mach white on outer feathers: hill and feet dark. Length, 5.25 inches.

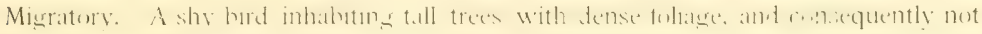

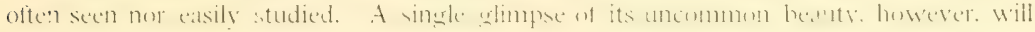

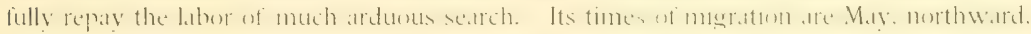
and September. southwart. It is then alumd.mt. thouph. as irtumated. a sharp ave. and some perseverance are required to detect it. 
PLATE XLVII. BLACK-THROATED BLUE WARBLER.

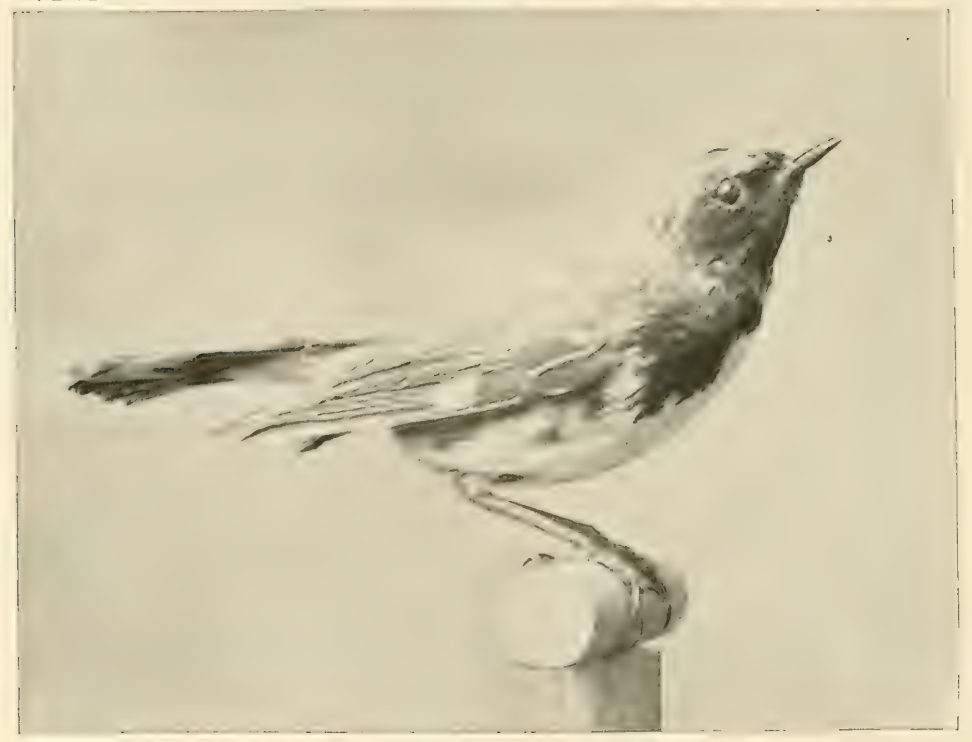




\section{PLATE XIVII.-BI.ACK-THROATEI) BI.UE WARBI.FR.}

\section{Dendroica carnlescens.}

Ahove wraly-blue : sides of heald, throat and sides of hody black: breast and helly white: wings dark. With a white patch. and some of the feathers edged with hlue: tail dakk, nearly even, some of its leathers bordered on the onter edere with blue and patched on some of the inner webs with white: hill hlack: feet hrown. Lemeth, 5.25 inches.

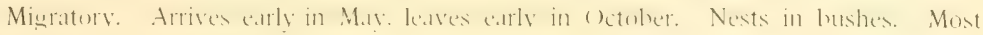
abundant during the migrations.

The tollewing extrots trom Mr. Burroughs admiably characterese the sonde and habits of this Warbler :

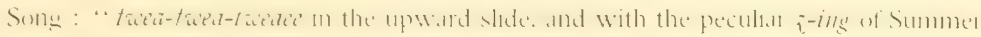

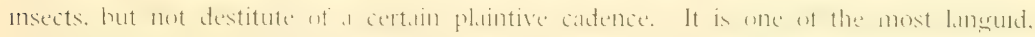

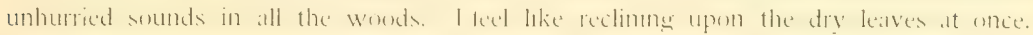

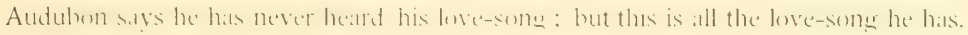

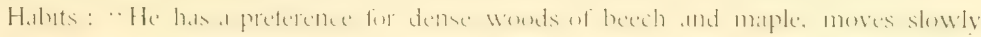

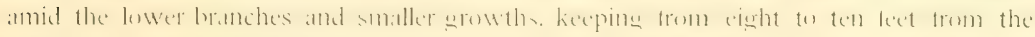
eround, and repeating now and then hes lastless. indolent strain." 


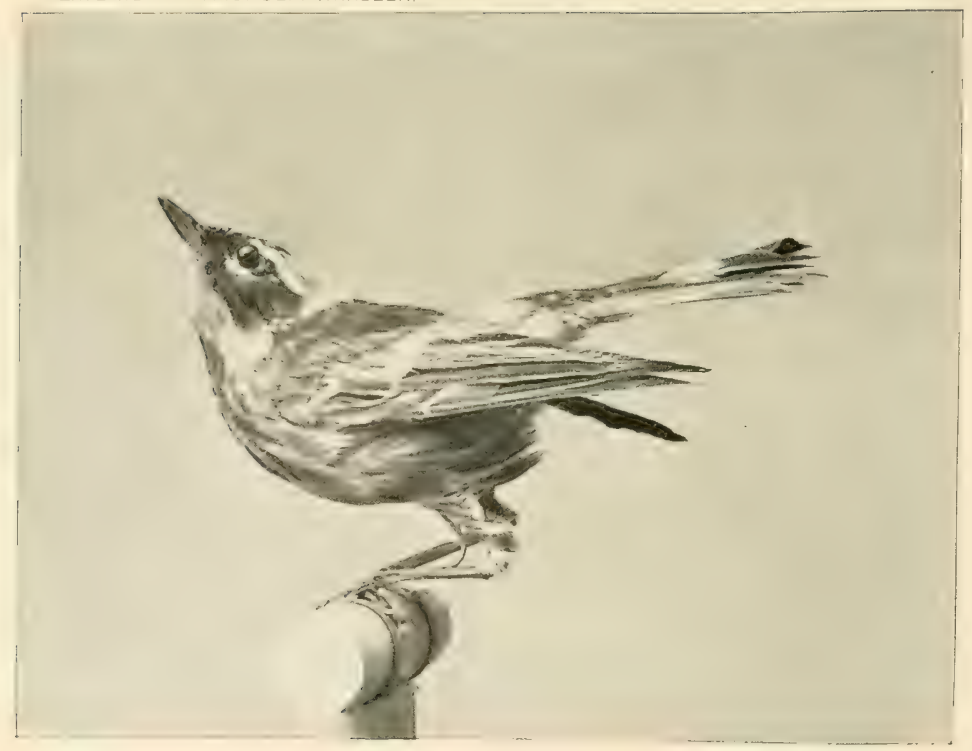




\section{PLATE XI.VIII.-BLACK AND YELLOW WARBIER. MACIN()LIA WARBLER.}

\section{Dentroica maculosa.}

Crown ash: back black; rump yellow: a white stripe commencess over the eye and extends biekward to the neck: chin and throat yedlow: breast yellow. but crossed and bordered hy lateral hack streaks which also extend allong the sides of the body: wings dark with a white patch. and many of the feathers pale-edged: tail dark and rounded. with white patches on? the inner weh of all the feathers except the midetle pair: bill and feet dark. Length, 5.10 inches.

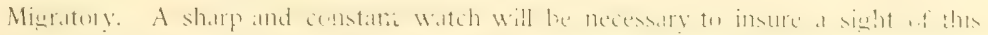

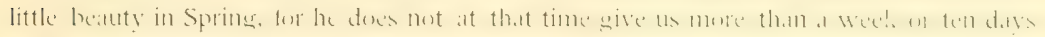

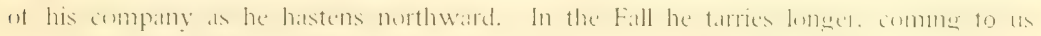

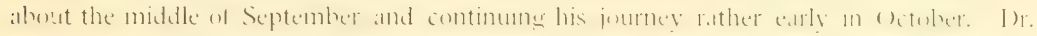
Mearns salys: " This heatiful species is partial to the hemlexk-tress. Whene it leceds in

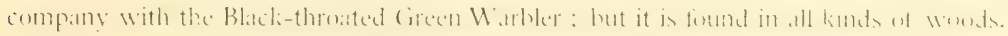

"It fiempently descends to the ground : sometimes inhabits low bushes." 


\section{PLATE XLIX. CHESTNUT-SIDED WARBLER.}

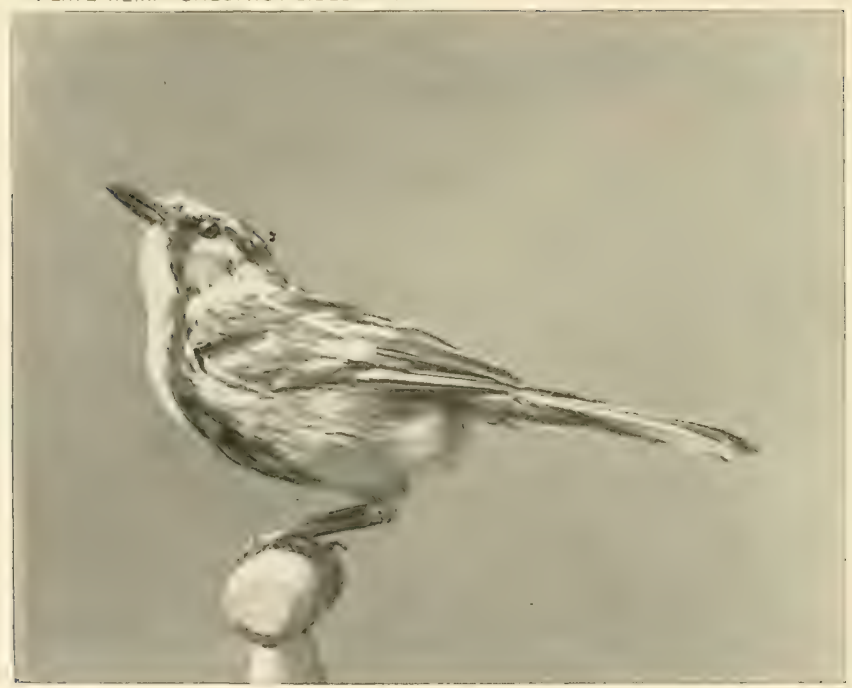




\section{I'LATF XIIX.CHESTNUT-SIDED WARBLFR.}

\section{Dendroica pensylvanica.}

Back streaked with Walk and greenish-yellow: a chestmut stripi on sides of bodn' crown yellow enclosed in white, and that in blatk; sides of head and entire under-parts white, but the white of the chese and throut is cut hy a blick streak which rums from hase of bill to the hewimning of the chestmut side-stripe: wings brown, with two indistinct hands, amd some of the feathers edged with yellow: tail homm, nearly syulle, and smmewhat spotted and streaked with white; bill dark; teet pale. Length, 5.10 inches.

Migrateny. Arrives enly in Mav leaves late in Septenber. Nests in bushes and small trees. Note monotonous and uninteresting. 
PLATE L. BAY.BREASTED WARBLER.

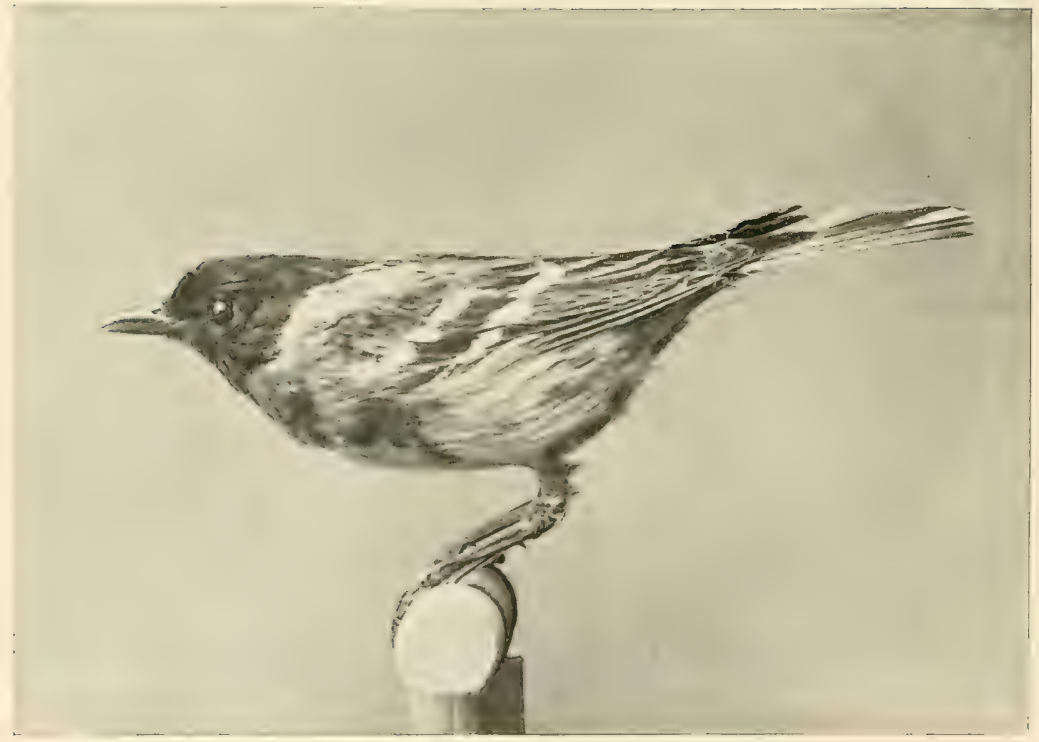




\section{PLATE L. BAY-BREASTEI) WARBLLER.}

\section{Dendroica castanea.}

Abore slate streaked with black: throat and sides chestmat: ientre of hreast and belly redish-white: crown chestont: forehead and cheeks back: a hull patale on each side of the meck: whess dark brown with two white bis: : tail dark hrown with some white hlotches: bill and feet dark. Length, 5.60 inches.

Migratory. Seen passing northward the latter hall wi Mats and retuming to the

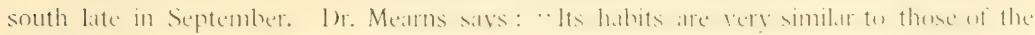
Black-pull. It is usurily seen in the tree-tops. where its movenents are rather heary and

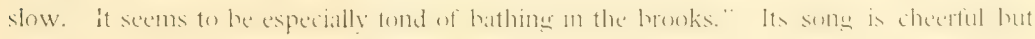
simple. 
PLATE LI. BLACK-POLL WARBLER.

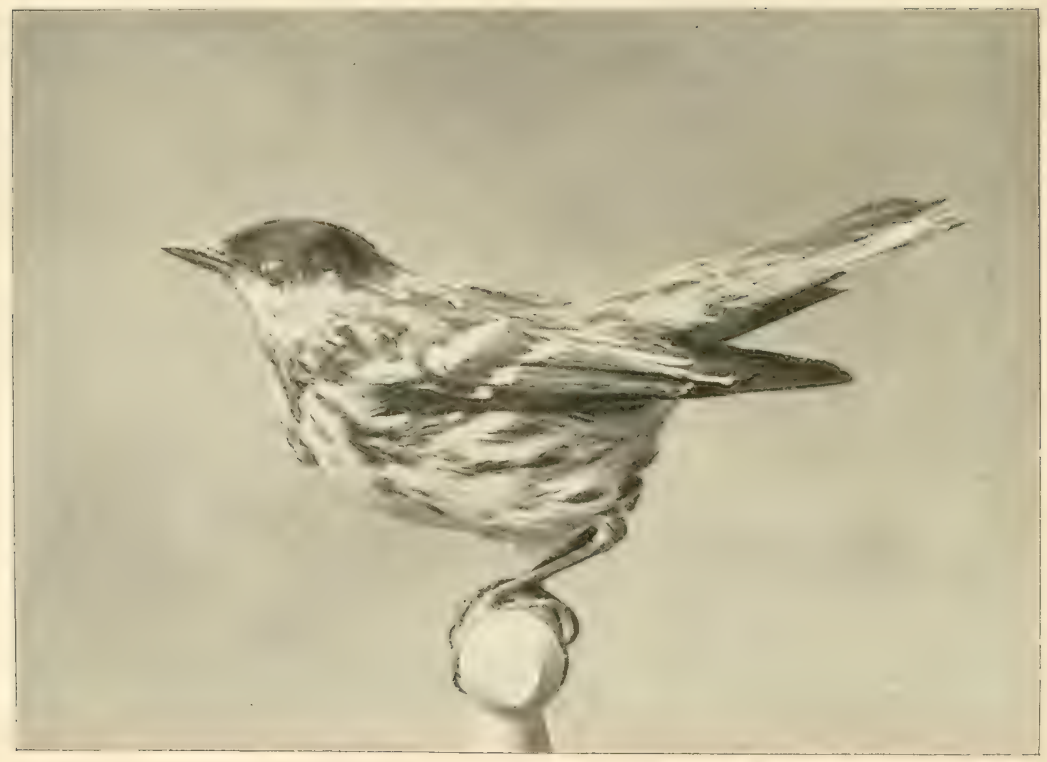




\section{P'LATE I.I.-BLACK-POI.L. WARBI.FR.}

\section{Dendroica striata.}

Head hlack streaked with hrown : back dark ash streaked with hlack: cleeks white: throat. hreast and helly white, hut all of them streaked on the sides with hlach: wings hrown with two light hands : tail splatre, hrown with white spots on some of the inner wehs: lower mandihle lighter than the uppere one: feet pale. Leneth 5.50 inches.

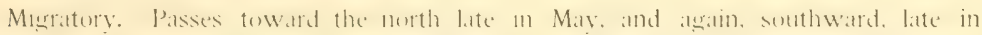
oitober. A brisk little fellow, lute exen kess of a singer than most of the soralled "Warblers." Rather abundant during migration. 
PLATE LII. BLACK-THROATED GREEN WARBLER

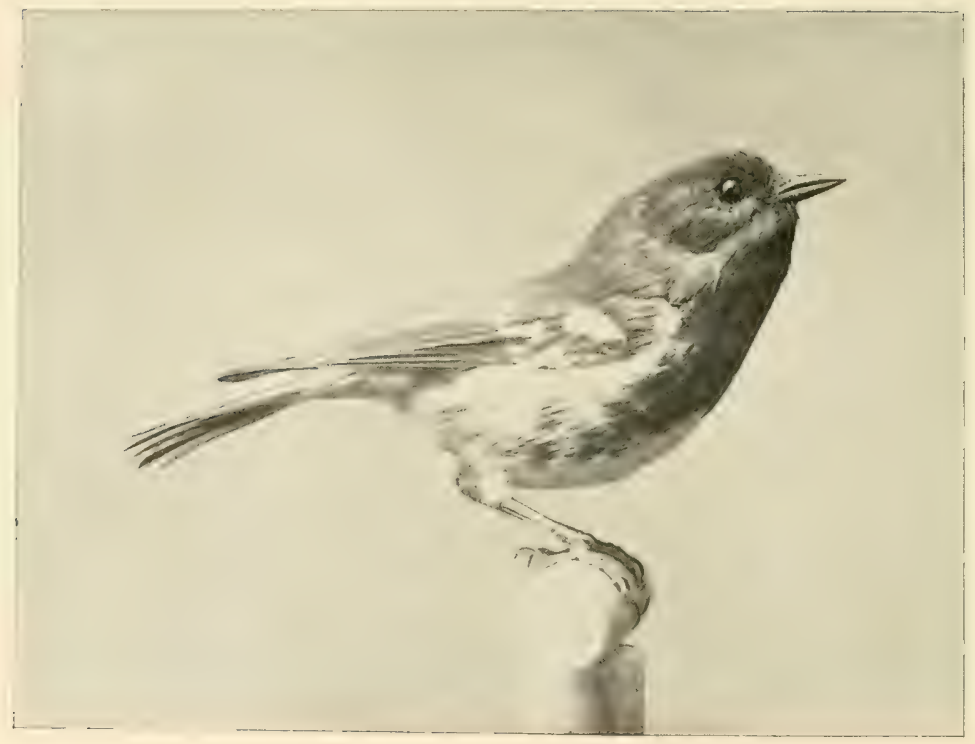




\section{PLATE LII.-BLACK-THROATED GREEN WARBLER.}

\section{Dendroica virens.}

Back and crown light yellowish-green: forehead, a hand over the eye, cheeks and sides of the neck rich yellow: chin, throat and breast black: wings brown, with two white bars, many of the feathers paleedged: tail hrown: the outer three feathers almost wholly white: bill and feet dark. Length, 5.10 inches.

Migratory. Arrives May 10, leaves october 25. This Warbler. like others of its fimily, is most frequently observed during its migrations. When for short periods it is rather abundant. It breeds here, however, and can be seen through the whole Summer.

It secms to prefer pine or hemlock trees, and usually chooses them to nest in.

1)r. Meams silys: "It is seen in large companies. clinging to the tips of the branches. exhibiting a fluttering of wings and incessant activity. Its atticudes and notes remind one of the Titmice ; but it possesses a very pleasant song besides." 
PLATE LIII. PALM WARBLER.

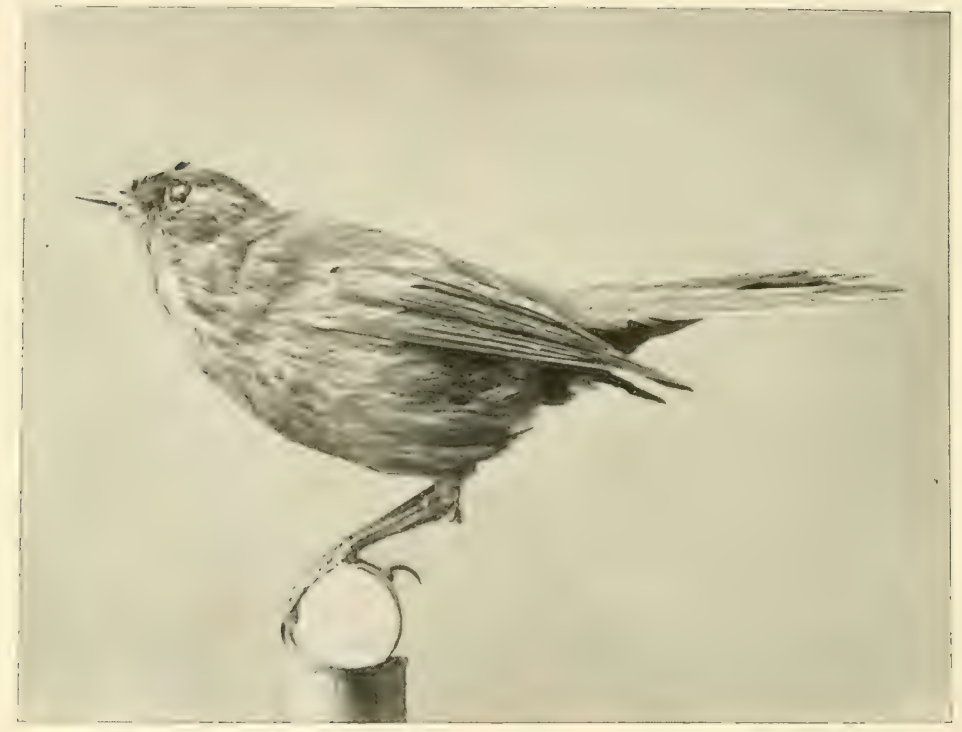




\section{PLATE LIII. YELIOW RED-POLL WARBIER. PALM WARBLER.}

\section{Dentroica palmarum.}

Above bownish-olive, rump gellowish-green: crown dark haly: beneath yellow, streaked on the breast with hay : a hright yellow streak orer. and at hrownish line through the eye: the two onter tall-feathers tipped with syuare white spots: no white wing-hars. lemeth. a fo inches.

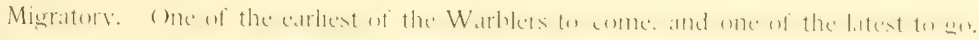

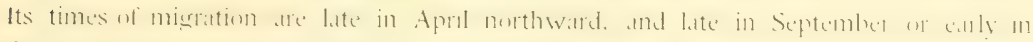

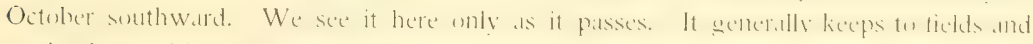

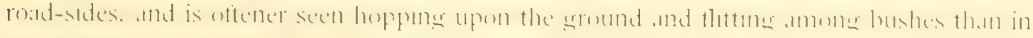

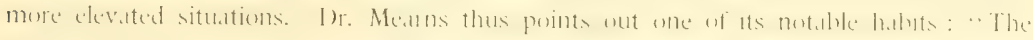

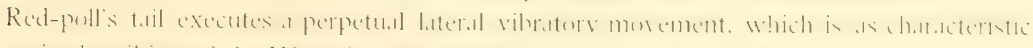

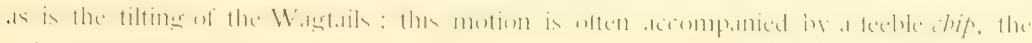
only note I have heard it utter," 


\section{MARYLAND YELLOW-THROAT.}

\section{Geothlypis trichas.}

Above olive-green, brownish on the head; chin, throat and upperbreast yellow: belly light buif, shaded on the sides with hrown: underside of the rump yellow: a hlack hand on the forehead passes backward through and heyond the eyes: wings brown. many of the feathers edged with light olive : tail nearly even. same color as wings: hill dark: feet pale. Length, 5.30 inches.

Minratery. Arrives early in Mary leaves early in octolber. Nests usually upen the ground, sometimes low in thickets.

A she bird: not eriven to frequent tlights. and generally seen hopping ahout upon the around or tlitting amongst the shrubbery. Song vigorous and rich, but not varied. 


\section{YELLOW-BREASTED CHAT.}

Icteria virens.

Ahove uniform olive-ureen : throat, hreast and lining of wings yellow: belly white, tinged on sides with hrown : a white stripe over, and a white patch under the eve: tail nearly even: hill hlack: feet hrown. Length, 7.50 inches.

Migratory. Arrives early in Maly leaves early in September. Nests in hushes. A shy birt. odd and ancouth in its motions and with an extranduraly song. Which Nuttall thus rather fancifuly descrubes: "Some of these motes resemble the whistlung ot the wings of a tlying duck. at first loud and raphe then sinking till they seem to end in single notes. ()ther tones are now heald like the barking of voung puppies. with a vartety af hollow:

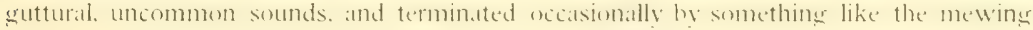
of al cat." The song is frequently heard moonlight nights.

The Chat is noted for its ventrilopuial powers. This art it empless with goend sucess in luring enemies from its nest.

1). Mearns, writing of one of ". its ridiculous performances, "salys : " It hals the habit of tlying up in the air. with its legs dangling. then allowing itself to drop nearly to the ground." 
PLATE LIV. OVEN.BIRD,

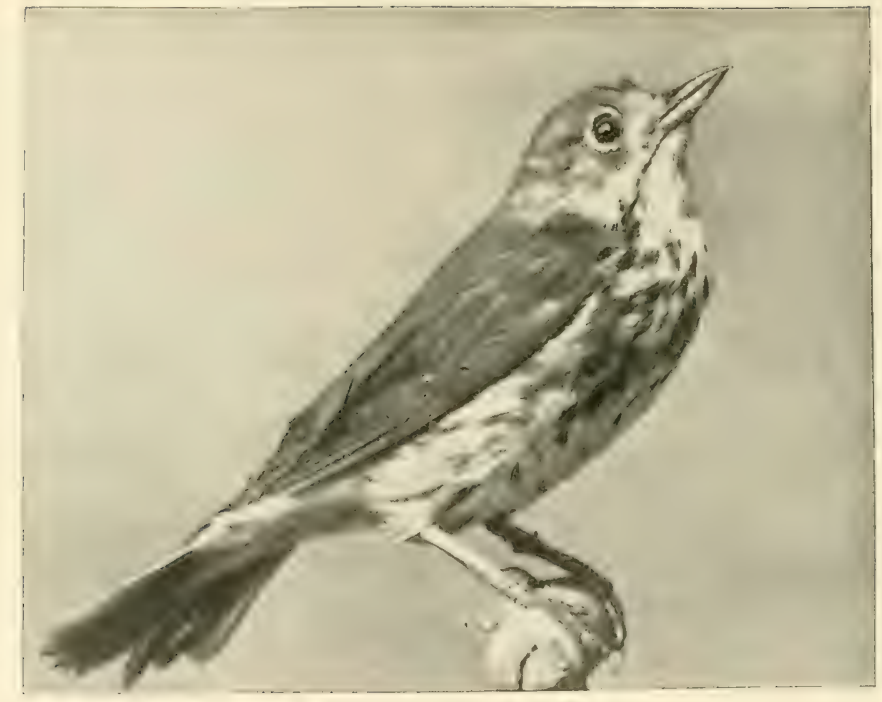




\section{PLATE IIV. - ()VEN-BIRI). (GOLIDEN-(CROWWEI) THRUSH.}

\section{Seiurus aurocapillus.}

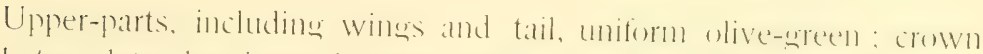
with two lateral stripes of hack inclosing a wider stripe of hrownishorange: a pale ring around the ere: underneath white with hlach spots and streaks on healst and sides: tail nearly event hill and lect pale. Length, 0.15 inches.

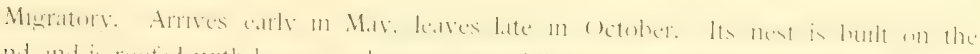

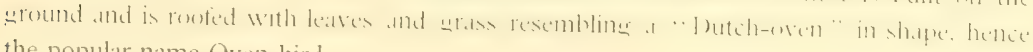
the popular name Oven-bird.

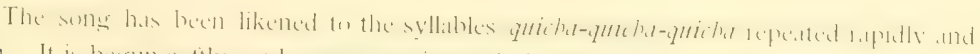

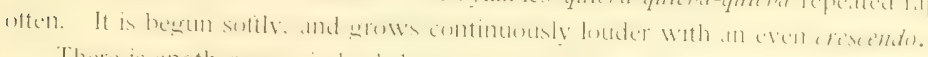

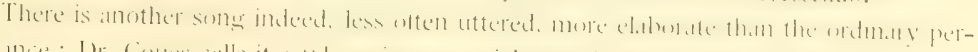

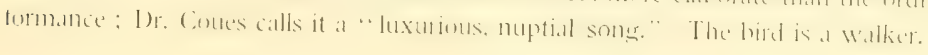




\section{HOODED WARBLER.}

\section{Syiviana mitrata.}

Ahove olive-yellow: forehead, cheeks, breast and belly bright yellow: crown, chin and neck all round jet black: wings and tail brown, the latter spotted on the three outer feathers near the tip with white: bill black: feet pale. Length, 5.05 inches.

Migratory. Arrives early in May, leaves early in September. A rather alundant bird. lovely in plumage, and a charming singer. It must he sought in remote spots. since it loves dense woods whose shelter it seldom abandons. It nests in low situations. 


\section{AMERICAN REDSTART. REDSTART.}

\section{Setophaga ruticilla.}

Head, neck, back and middle-hreast blue-hlack: sides of breast orange : helly white: wings with an orange hand and lined with orange: tail slightly rounded. Wlack, hondly patched on each side near the base with orange: bill and feet black. Lemeth. a. fo inches.

Mieratory. Arrives carly in Mar. leaves late in September. Nests on small trees in woods or meadows. A rather shy bird. with a sweet but momotomens songe. 
PLATE LV. CATBIRD.

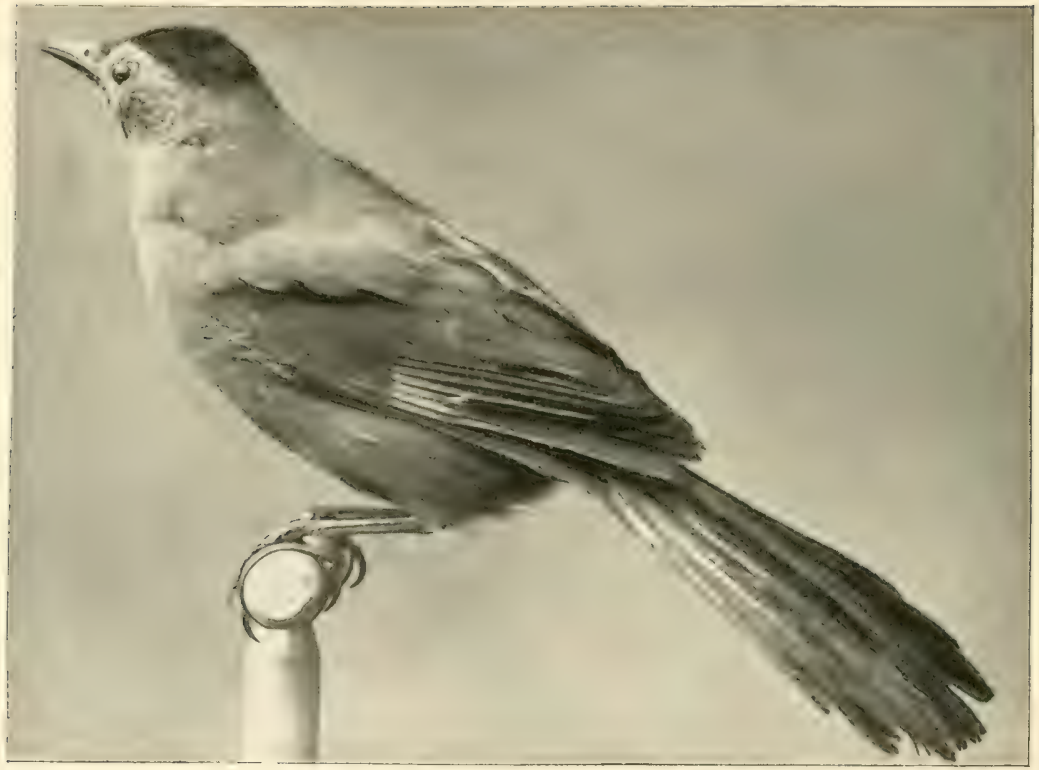




\section{PLATE LV.CATBIRD.}

Galeoscoptes carolinensis.

Prevailing color slate, palest helow : under-side of rump reddish: crown, tail, bill and teet black: tail tull and rounded. length, s.(e) inches.

Migratory. Arrves early in May. kedves about octoher 19. Nists in bushes. A

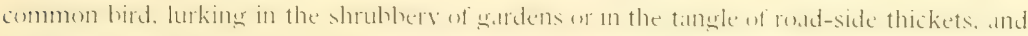

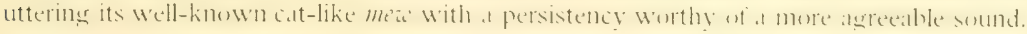
Another of its cills. even still less musical, resembles the syllables trat-fat-fut-tat given an quick succession.

It has however, a beatutiful songer whath has been called a medleve imitative of the Rohin and the Throsh. This somer is heatrd only deming the hreeding season, and though

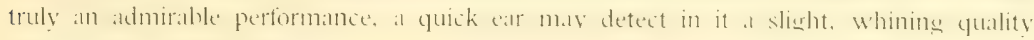
suggestive of the feline note.

The but is really a handsome onc. hut. owing to its skulking hahits, and the unserial manner with which it resents inspection. searcely at fivorite. 


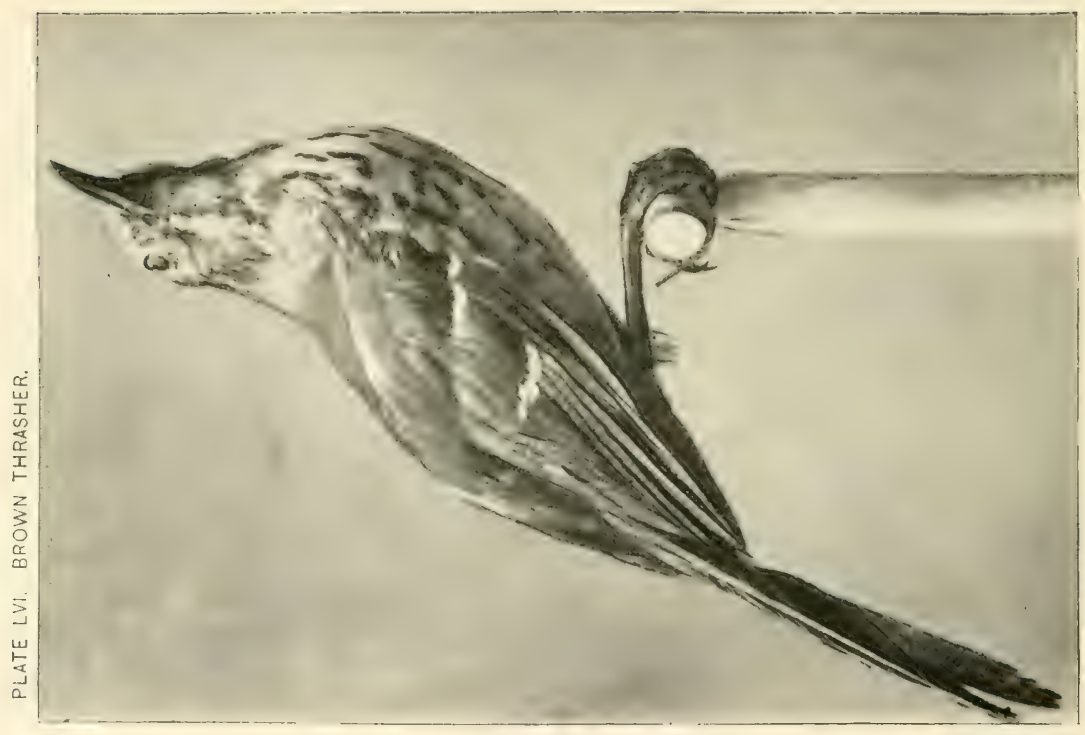




\section{PLATE LVI.--BROWN THRASHER. BROWN THRUSH.}

\section{Harporbyncus rufus.}

Above light reddish-hrown: throat, middle of helly and underrump white-but, inclosing the throat, and on breast and flanks much spotted with brown: two white barson wings: tail long and romoled: bill dark: feet pale: iris yellow. Length, 11. fo inches.

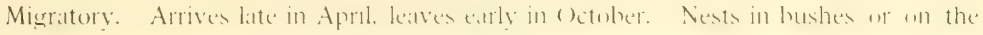

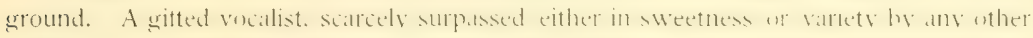

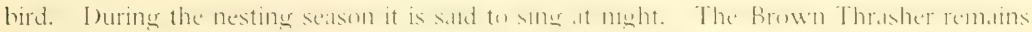
for the most part in the cover of thickets in whose recesses he has his nest. lut when the

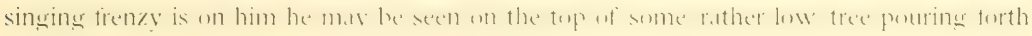
his melody.

When the sun illumines his howwe eolt, the tint of led in at is strikingly apponent. 
PLATE LVII. WINTER WREN.

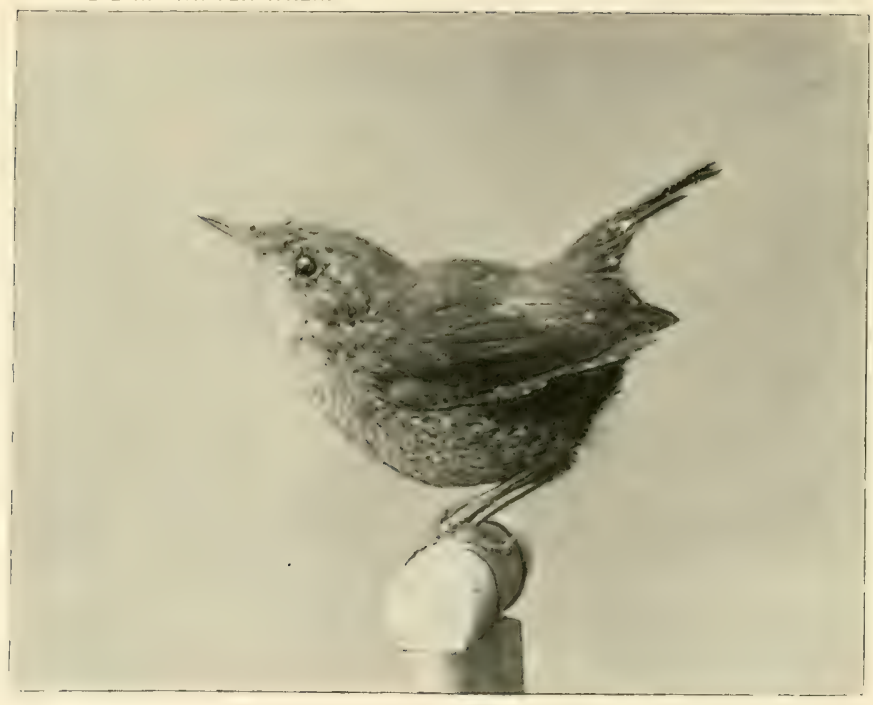




\section{PLATE LVII.-WINTER WREN.}

Troglodytes biemalis.

Reddish-brown all over. darker on the hack: harred and spotted everywhere except on head and neck: tail vers short and rounded: a pale, indistinct line over the eye. lemeth, finches.

Migraters: Arrives from the north in ()etoher and returns in the Spring. Next to the Hemminglird, the smallest bind we have. It is extremely shy and as lor. Cones remarks. "less often seen than wher Wrens me less common: voloc strong and highly musical." 


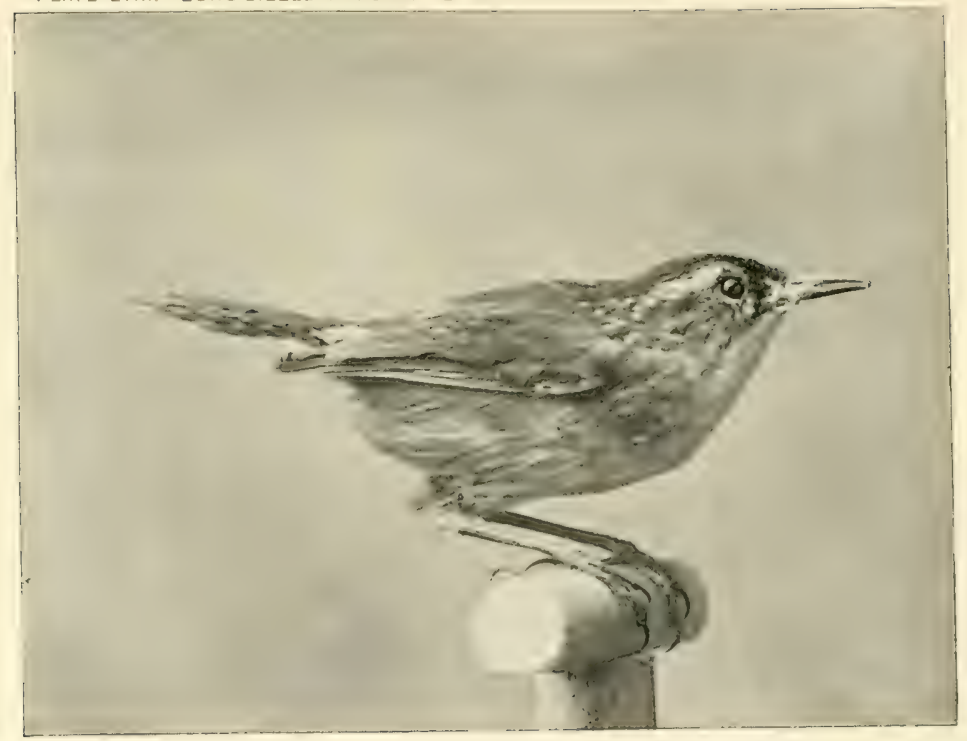




\section{PIATE IVIII, - LONG-BILLED MARSH WREN}

\section{Cistotborus palustris.}

Above reddish-hrown: head and hack of the neck hlack, sometimes streaked with white: beneath white, shaded on the sides with hrown: wings and tail much harred, the latter short and rounded: a pale streak over the eye. Length, 5.20 inches.

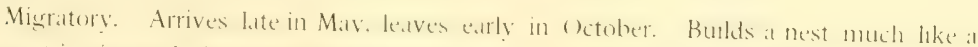

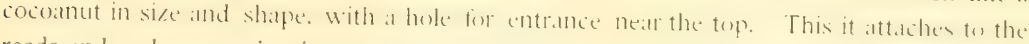
reeds and rushes growing in swamps or marshes.

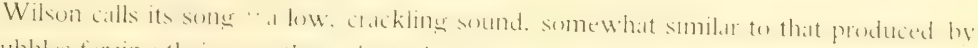

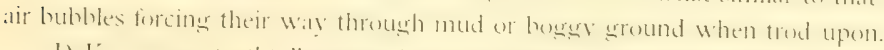

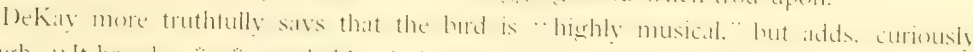
enough, " It hreeds * probally (!) in this State (N.Y.). hut I have met ret met with its nest." The write hals found the but at very common ane : he has secen mams of its

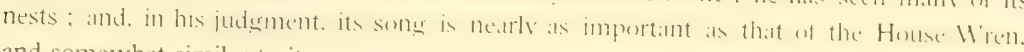
and somewhat similar to it.

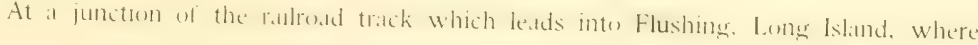




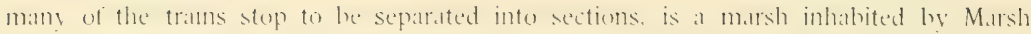

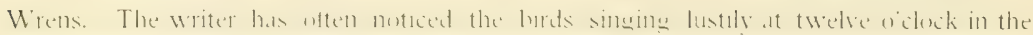
mesht. and suppesed that they were wikened he the molse of the cars. He is interested.

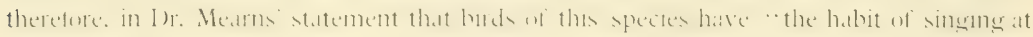
night when the nom is hight." He intends to kenn it the Flushing colony sing when there is mo moxn. It he tinds this to he the colse. he will comtinue to ascribe the madnight seremede to the disturhing intlueme of the passme trans.

\section{HOUSE WREN.}

\section{Troglodytes aedon.}

Ahove reddish-hrown, lighter towards the rmmp: heneath soiled white with hrown tinges on the heast: wings and tail moch halred. the latter rounded: a light line over the eye. Length. a inches.

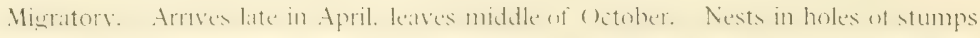

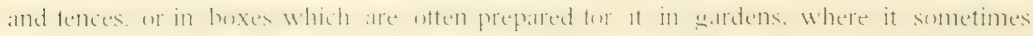
brings forth three broods.

He whes studies the House. Wren as it is seen alreut mens habitations, will sily that it 
is a cheerful, industrious little ireature, with chaming ionfictence in mankind. He also

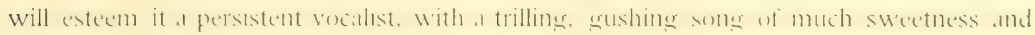

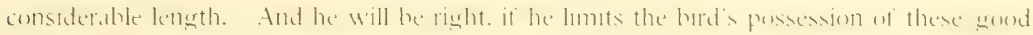

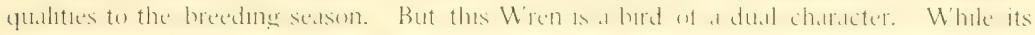

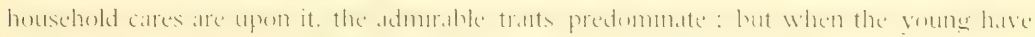

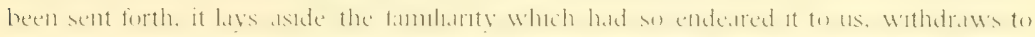

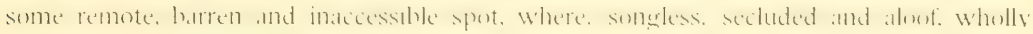

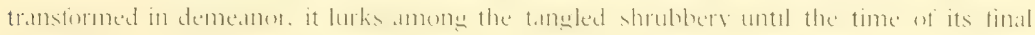
departure. 


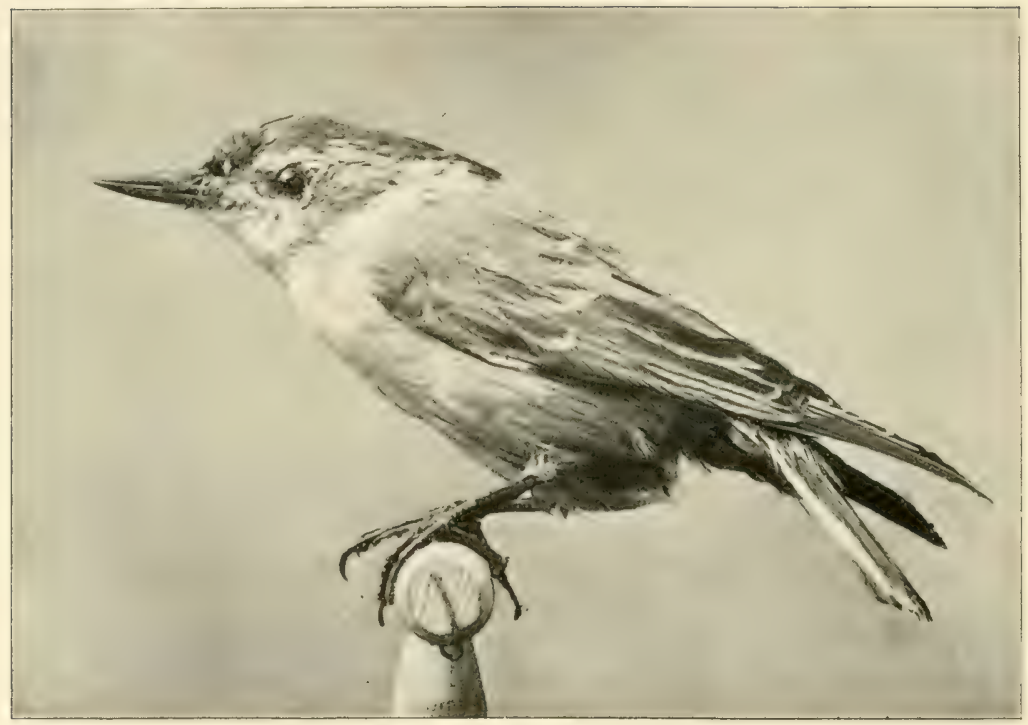




\section{PIATE I.IX. WHITE-BREASTEI) (OR BFILLED) NUTHATCH.}

\section{Sitta carolinensis.}

Crown and hack of neck black: back gray-blue: checks, throat, breast and belly dull white: wings dark, many of the feathers lightedged: the middle feathers of the tail gray-blue, the outer ones marked strongly with hlack and white: hill and feet dark. length, o inches.

Resident. Nests in a hole generally made by the brot itsell in a trete or stump. It has no somg. Wut utters a shont. harsh call. which resembles the sillable ghrmb. It clambers up. down or around trex-trumks, of runs alenge the upper or under side of a branch with

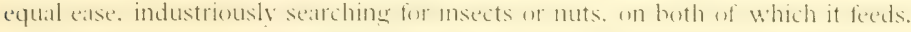

In separating the ketnels of mots trom the husk or shell. it wedges the nut inte al crevice of bark or limb, and pounds upon it until the shell gives waly.

The bird is an acomplshed grmmast. hanging. salss l)r. Coues. " in every conceivable attitude. head downward as often as otherwise." 


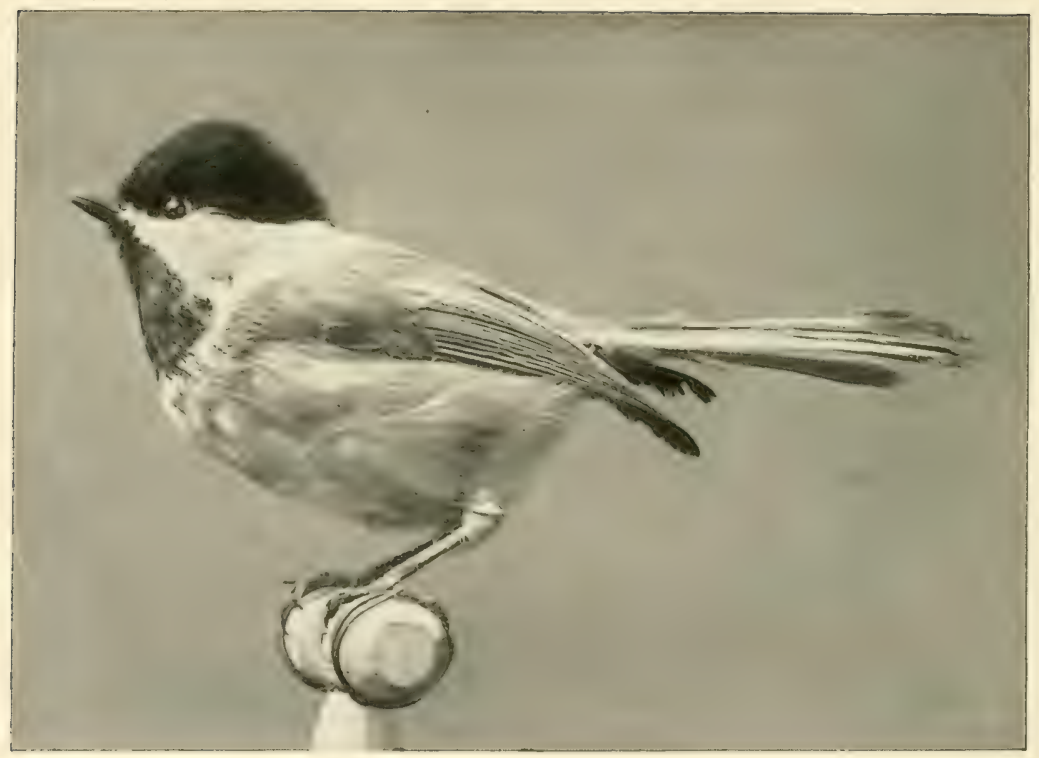




\section{PLATE IX.CHICKADFE. BI.ACK-CAPIEI) TITMOUSE.}

Parus atricapillus.

Prevailing color graly-hrown : crown and throat black: cheets white: hrealst and belly dull white: tail nearly squale: Lemeth. $=.25$ inches.

Resident. Nests in holes in trees on stumps. Flght wavering. A nervously active little fellow, constantly in motion. Fearless and contidings, it wall pursue its avocitions in

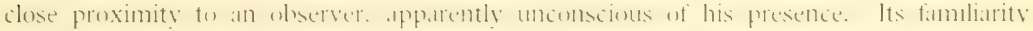
with man and contidence in hom are very torehemes, and thes trait. no less tham its cheery call and industrious habits. endears it te all bird-leneers. It is often observed in company with Wrens and Nuthatches. In Fall and Wuter the (hackatere is one of the most abund-

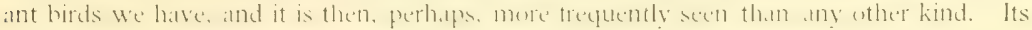

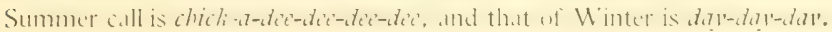


PLATE LXI. GOLDEN-CROWNED KINGLET.

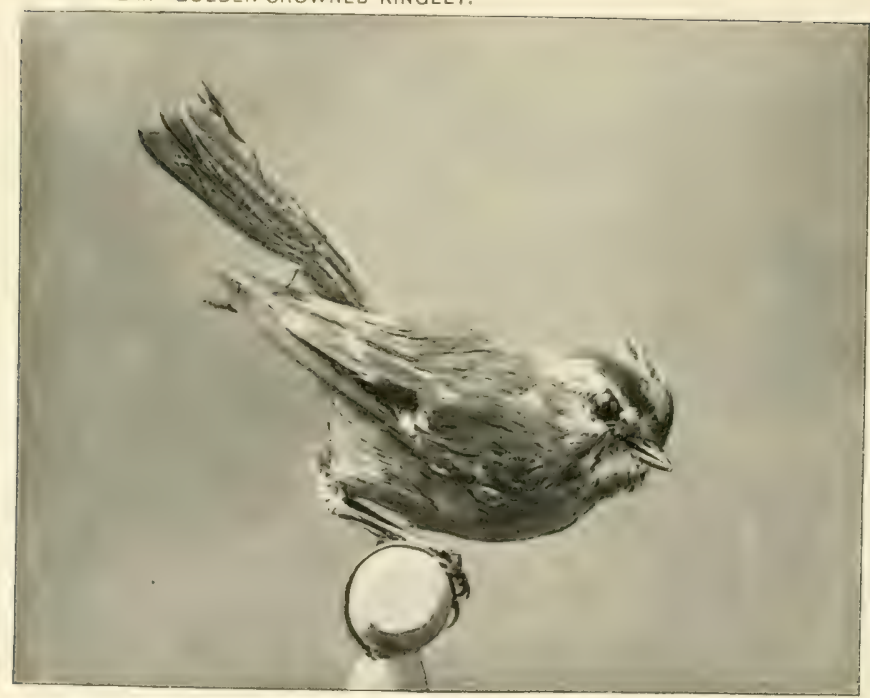




\section{PLATE LXXI-GOLDEN-CROWNFD (()R CRESTED) KIN(BLET.}

\section{Regulus satrapa.}

Above olive-green: heneath dull white: crown as follows: in the centre a stripe of orange surmunded on front and sides hy gellow and that in the same manner hy hlack. and that agan similaty hy light graly: wings hrown, most of the feathers with pale edoes: tail hrown, notched: hill blakk: feet dark. length, f imches.

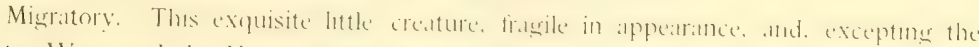
Winter Wren and the Humminghird, the tinnest of aur hirds, is, in lact a hardy coldt

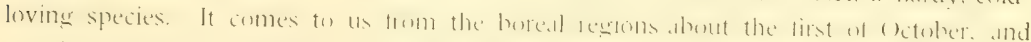

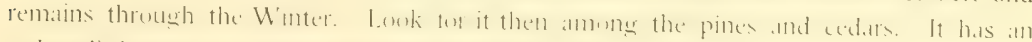

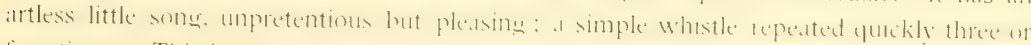

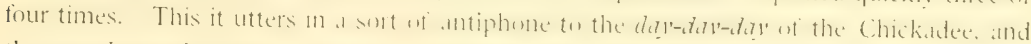

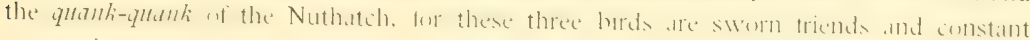
companions.

The Golden-crowned kimglet is mo lower of warm weather. Such expernence as

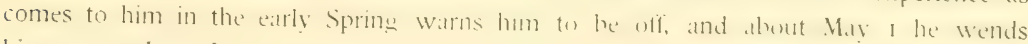
his wav northward. 


\section{RUBY-CROWNED (()R CRESTED) KINC;LET.}

Regulus calendula.

Much like the preceding. exeept that it is a trifle larger. the olivegereen of the hack is darker, and the orown is als follows: eneneral color olive-green, a remmilion patch in the centre. and the forehead light gray. Length, 4.40 inches.

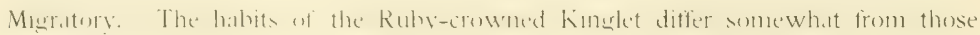
of its congener.

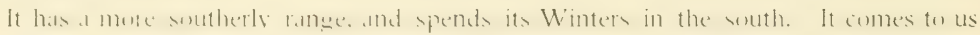

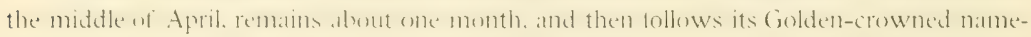

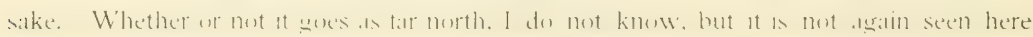

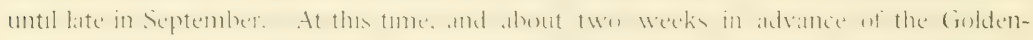

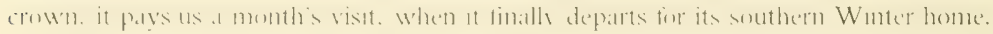

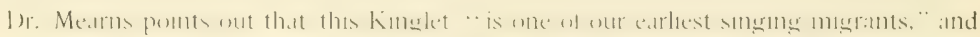

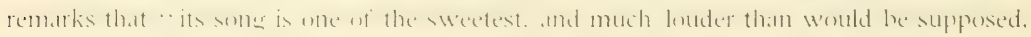
coming from such a little bird." 


\section{HERMIT THRUSH.}

Turius aomalascbker pallasii.

Above olive-brown. passing to a deidedly ridelist color on the tail; heneath white, tinged with yellow an the hreast, and with araty an the sides: throat pure white, hordered with hoown spots. -these spots extemd down upon the hreast and alle of a shape called arrow-healded: a gelfowish ring aromol the ere: tail rather short. meatly even: bill dark hrown, - the lower mandible much the linhter: less light hrown. Length, 7.15 inches.

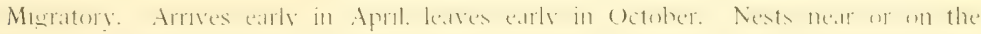

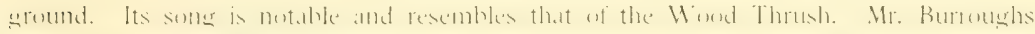

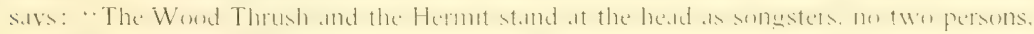

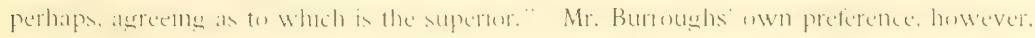

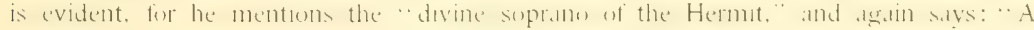


PLATE LXII, WOOD THRUSH.

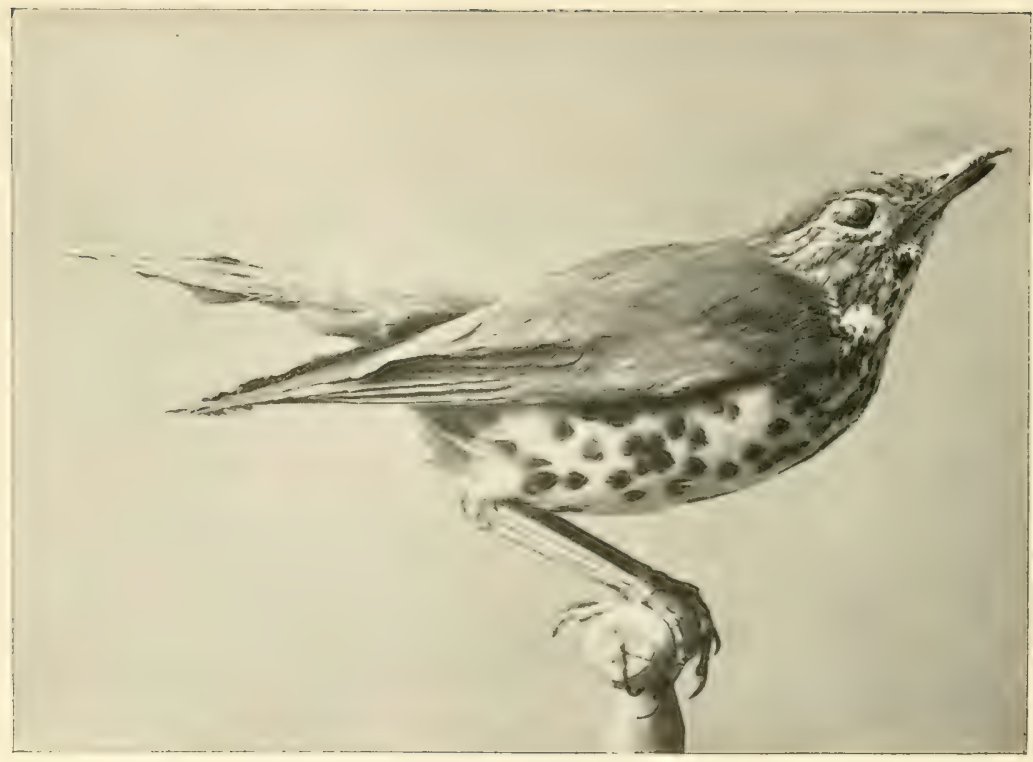


strain has reached my ears **** that to me is the tinest sound m mature-the song of the Hermit Thrush."

The beginner will he puzzled to discriminate hetween the several Thrushes. As

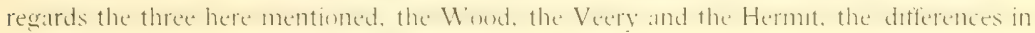
the color of the back will guide him aright.

Miss Merriam thus concisely states these variations :

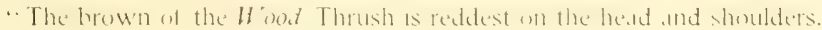

"The brown of the Hermit is reddest on the tail.

"The Tarny has a uniformly tawny back."

\section{PLATE LXII.-WOOD THRUSH.}

Turdus mustelinus.

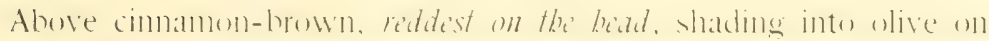
the rump and tail: leneath white, thickly snotted on hreast and sides with dark-brown, hut the chin, throat and midelle of belly are immaculate: tail nearly even: hill hromm: leet pale. Length, 8.25 inches.

Migratory. Arrives early in May, kelles l the in September. Nests uaually m wouds. 
PLATE LXIII. WILSON'S THRUSH.

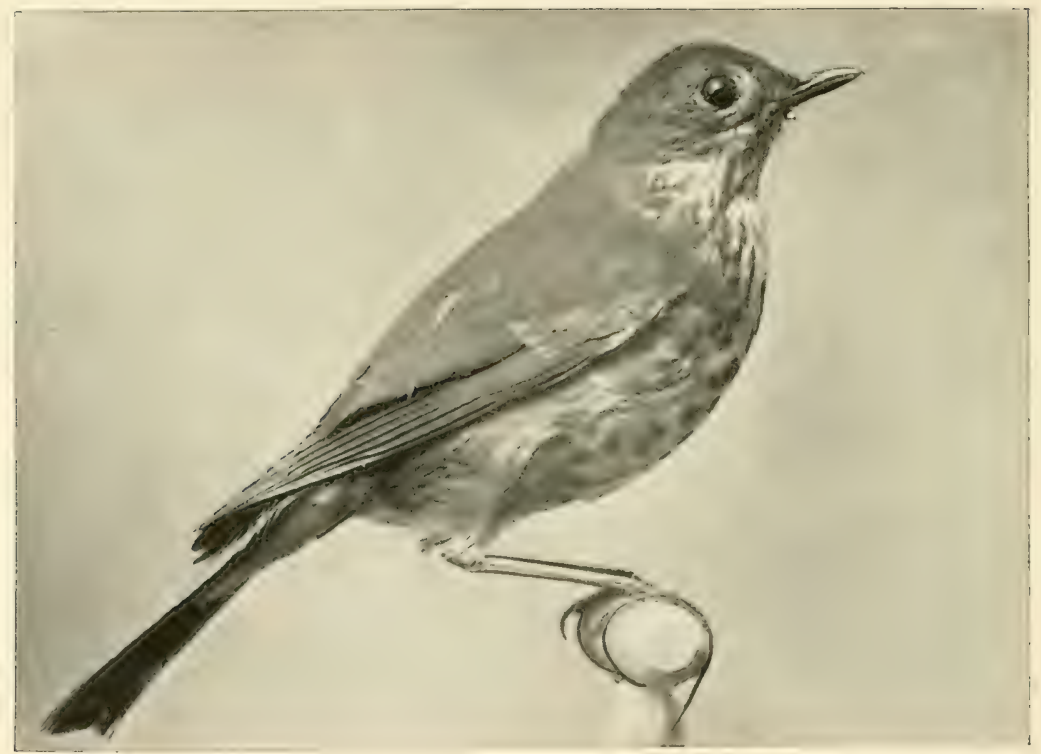




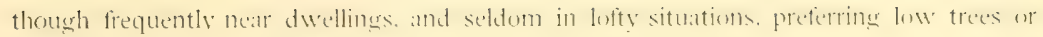
even bushes for its dwelling place.

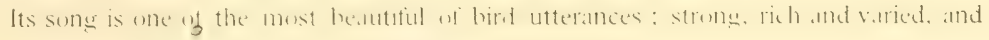
with a peculiar metallic equality betemernes to no other bird.

\section{PLATE LXIII.--WILSONS THRUSH. TAWNY THRUSH. VEERY.}

\section{Turdus fuscescens.}

Above reddish-hrown, neall iontinnous in shate. including tail: beneath white, less pure on sides, and even yellowish on throat and upper-breast: spotted with hromen on the breast and sides of the throat: tail rather short and slightly mothed: upper mandihle darker than lower one: feet palle. Lemeth, 7.an inches.

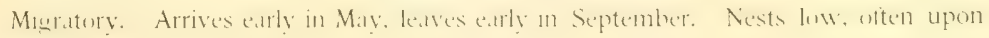
the ground.

A shy bird, frequenting dark woods or swamps.

A fine singer. 
PLATE LXIV. AMERICAN ROBIN.

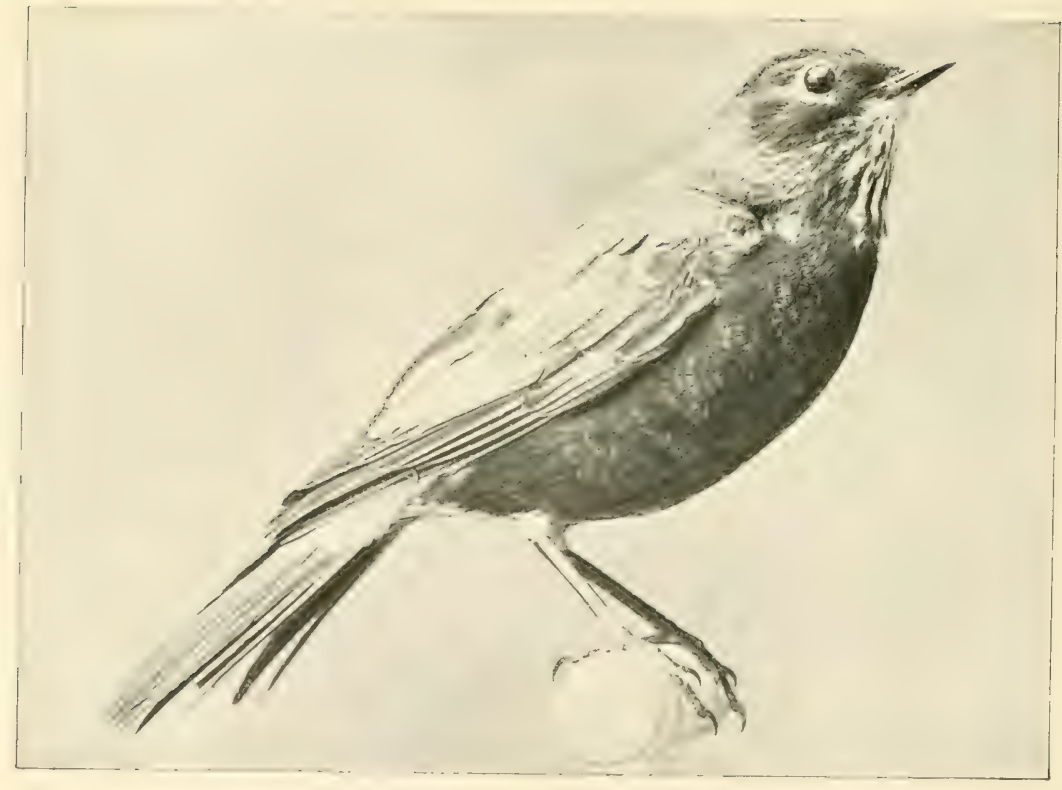




\section{PLATE LXIV.-AMERICAN ROBIN. ROBIN.}

\section{Merula migratoria.}

Above olive-gray: head black: throat white streaked with black: eye-lids and a spot before the eye white: hreast and belly chestnutbrown: under-side of rump white: wings dark hrown, some of the feathers with light edges: tail black, slightly rounded, the outside feathers tipped with white: bill yellow : feet dark. Length, oo inches.

A migratory species. Those individuals which sometimes pass the Winter here are probably birds with a more northerly range than the others of their kind. The Robin arrives in full force early in March and remains until late in the Fall.

Nests usually in trees, the structure being composed largely of mud.

During the breeding seatson a persistent vocalist. and if the sone has not much variety. its heartiness and good cheer render it one of the most atgreeable of bird utterances.

Many persons who cultivate cherries, grapes and other small fruits are prejudiced agrainst the Robin. believing it to be destructive to their crops. Such enmity is ill-firunded, for fruit is a small part of Rohin's diet. and, by the havoc he creates amoner worms and 
insects. he much more than compensates for the damage done by his occasional lapses into vegetarianism. The quantity of worms and insects which he devours is enormous, indeed hardly credible. Professor Treadwell experimented on some young Robins kept in captivity. with a view of determining the amount of food necessary to maintain them. and found that each one required sixty-eight worms per day. That is to say, each bird "ate forty-one for cent. more than its ow'n wight in twelve hours. The length of these worms. if laid and to end. would be about fourteen feet. Man at this rate would eat about seventy pounds of tlesh a dily, and drink tive or six gallons of water."

Well may Mr. Thonlas Wentworth Higginson. in OLT OF LOOR PAPrs, exclaim at the "exhatusting labor of yonder Rolvin. whose winged, picturesque day is spent in putting worms into insatiable heaks at the rate of one morsel in every three minutes."

The American Robin must not be confounded with the Robin Redloreast of English nursery tales. The two are not at all alike. The American Bluebrd approaches most nearly of anv of our birds to those which provided the celebrated sleeping habes with their leafy covering. 


\section{BLUEBIRD.}

\section{Sialia sialis.}

Above azure-hlue: throat and upper-breast cimmamon: helly dull white: eyes large: tail and wings broad, the former slightly notihed: bill and legs black. Length, 7 inches.

A migratory species: indivituals. probathly those with the northemmost ranger heing usually present with us through the Winter.

Arrives carly in March or even in Felmuary. leaves late in November. Somes a solt, pleasing wathle in which a resemblance to the syllables tru-al-ly often repeated has been noticed. The hird utters this song when he is tlying and when he is at rest.

Nests in holes of trees or posts. or in hoxes placed for his use m gardens.

() ne of the carliest comers. the Bluebird is gladly welioned as a harbinger of sproten. and his arrival is more widely remarked than that of most of the other lords. As the season advances and the tide of migratoon sets tully in. he loses his prommence until. In Fall, many of the Summer visitors having departed, he argan assumes importance: 
then, after greeting the Juncos and Snowtlakes just come from the north, and bidding adieu to his mtimate frends. the Chickadees. he joins the Kinglets and Warblers. now on their southern journey, and who tarry long enough for him to malke his final preparations. and with them he seeks a sunnier clime. On some plealsant November morning, when we hear his sweet warble fiom an adjacent kence. though at the time we are unable to interpret the burden of his lay, he is, in his ow'n "grentle, high-bred manner." bidding us

FAREWELL. 


\section{COIOR-GUIDE}

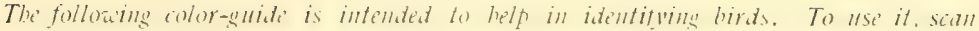
the left column antil a beading is tound that indicates a color correspomiting to the most noticeable mathing of the bird whose name is desiret. If. under this beatine, there stand sub-hedings, sec if the unkmon bird has peculiaritios mentioned in one of these. The comparisons baving bien acolrately made, the reader mal feel reasonably sure that be bas reached the right mame. Furtber contirmation mall be sought from the descriptions in the body of the book, fo which the figures in the right column reter.

Back asb.

Bank Swallow. KINGBIRD.

PAGE Back black.

PAGF

145 Belly white; sides chestnut.

81 CHEWINk.

Buck ash, striatied with blati.

Head black; cheeks white.

BLACK-POLL. WARBLER,

Belly and rump white: breast rosered.

Back black.

Head. neck and middle-breast blick: sides of breast and tail-patches orange; belly white.

AmERICAN RedstaRT.

Back black and orange.

Rose-Breasted Grosbeak.

Rump yellow.

$$
\text { Marinotis W. mklater. }
$$

Baltimore Oriole. 
Back black and white.

DOWNY WOODPECKER.

HAIRY WOODPECKER.

Breast orange.

Blackburnian Warbler.

Head, and neck all round. crimson.

RED-HEADFD WOODPECKER.

Back asby-blue.

NORTHERN SHRIKE.

Crested.

BÉlTed Kingfisher.

Throat, sides of head and of body black.

BI.ACK-THROATED BIUE W ARBLER,

Crown and back of neck black: under-parts white.

Whith-BREasted Nuthatch. 197

67
Back aqure-blue.

PACFF

67 Breast cinnamon; belly dull white.

BLUEBIRD.

2 I I

Back light blue.

BLUE JaY.

QI

A patch of yellow in centre of the back; breast yellow, somewhat spotted with brown.

PARULA WARBLER.

Back slaty-blue, streaked witb black.

Crown, rump and a spot on each side of the breast yellow.

MYrTLE: Warbler.

Back steel-blue.

Underneath chestnut.

Barn SWALlow.

Back gray.

LF.AST FI.yCATChER.

sis 
Back olize-gray.

Head black: throat white streaked with black; breast and belly chestnut.

ROBIN.

Back olize-brown.

PHOEBe.

WOOD PEWEE.

Beneath white with many brown spots.

Hermit Thrush.

203

Back metallic-green.

Ruby-Throat'd Humm G Bird. $7^{8}$

Back olive-green.

Great Crested Flycatcher. 83 Kinglets (very small birds).

201,202

Beneath white, spotted and streaked with black.

OVEN-BIRD.
Back olive-green.

TAGF

Beneath yellow (more or less pure).

Maryland Yellow-Throat. 180

Yellow-BELLIEd FlycatChER. 87

Yellow-Breasted Chat. 181

Yellow-Throatel) Vire(), 151

Eyes red.

RED-EYED VIREO.

Eyes white.

WHITE-EYED VIREO.

Head blue-gray.

SOLITARY VIREO.

Head buff, striped with black.

WORM-EATING WARBLER. 160

Back olive-yellow'.

Forehead, cheeks, breast and belly bright yellow; neck all round, crown and chin black.

HOODED WARBLER. 
Back reddish-brown.

pace Beneath white (more or less pure).

Beneath white spotted with brown.

Brown Thrasher.

189

WILSON'S THRUSH.

WOOD Thrush.

Back slate, strialial witb black.

Throat and sides chestmut; belly and centre of breast reddish-white.

BAY-BRFASTHI) WARBIFR.

Back sooty-brown.

Throat light gray.

Chimney SWIFT.

Back wbite.

Hind-neck cream color; all else black.

BOBOL.INK (in nuptial plumage). $9 \overline{7}$

Back yellowisb-green.

Chin, throat and breast black: forehead, a band over the eve, cheeks and sides of neck vellow.

BI AK-THRGATII (IRH. N W ARBLER.
Cricions. (1) 102

DOWNY WOODPECKER.

HAIRY WOODPECKER.

KINGBIRD.

L.RAST FLYCATCHFR.

So)

NoRTHHRN SHRIKL.

PHCEBE.

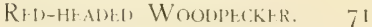

White-BREASTED NuthatCh. 197

WoOd PEWEE.

A brown band across the hreast.

Bank Sivallow.

Sides chestnut.

CHEIVINK.

Streaked on sides of body with black.

BLACK AND WhITE W ARBLER. 159

Streaked on sides of hody with black: head blick: cheeks white.

BLACK-POLL W ARBLER. 
Beneath white (more or less pure).

Breast or belly (or botb) chestinut.

PAGE

Throat, sides of head and of hody black; back grayish-blue.

ORCHARD ORIOLE.

BlaCK-THROATED BLUE WarBLER.

A chestnut stripe on each side of the body,

ChestNut-SIDED W ARBL.FR. 171

Spotted with brown or black on breast and belly.

$\begin{array}{ll}\text { BROWN THRASHER. } & 189 \\ \text { OVEN-BIRD. } & 183\end{array}$

Thrushes (HERMIT, WiLSON'S

$$
\text { and WoOD). 203-207 }
$$

Breast or belly (or botb) brigbt orange.

BALTIMORE ORIOLE.

BLACKBURNIAN WarbLER. 104 165

Breast or belly (or botb) chestuut.

BaRn SWaLlow.

BLUEBIRD.
Breast rose-reit.

Belly white.

Rose-Breasted Grosbeak. 137

Breast or belly (or botb) spotted or dasbed.

BROWN THRASHER.

189

FLICKER.

FOX SPARROM: I I

HORNED LARK. 93

OVEN-BIRI. $\quad 183$

THRUSHES (HERMIT, WILSON'S and WoOp). 203-207

Breast or belly (or botb) more or less y'ellow'.

AMERICAN GOLIFINCH. 112 GRAT CRESTED FLYCATCHER. 83 MARYLAND YELLOW-THROAT. ISO PARULA WARBLER. 101 RED-EYED VIREO. I53 
Breast or billy (or botll) more or le'ss page yellow.

Yelluw-Bellied Flycatcher. 87

Yellow-Bellied SAPSUCKer. 69 Yellow-BREASTED Chat. I81

YELLOW-THROATED VIREO. I5I

YELLOW WARBLER.

Crown bay.

$$
\text { Palm Warbler. }
$$

Forehead and cheeks yellow; neck all round, crown and chin black.

HOODED WARBLER.

184

Large black crescent on neck.

MEADOWLaRK.

101

Throat, chin and rump yellow; back black: black streaks on breast and sides of body.

$$
\text { MAGNOLIA WARBLER. }
$$

'Breast lilac-brown, with a large', black pagp balf-moon.

Belly ashy, plentifully spotted with black; rump white.

FLICKER.

Crested (more or less).

$$
\text { Belted Kingfisher. }
$$

BLUE JAY.

Cardinal.

Cedar Waxiving.

Great Crested Flycatcher. 83

KINGBIRD.

81

PHCFBL.

85

WoOd PEWEE.

General color ash.

Head crested: tail with a yellow terminal band. 
General color black.

COWBIRD.

CROW:

PuRPLE Grackl.F.

Shoulders red.

RED-WINGED BI.ACKBIRD.

Sides of body chestnut.

Chewink.

Tail-patches and sides of breast orange ; belly white.

AMERICAN REDSTART.

General color blue.

INDIGO BUNTING.

Crested.

Belted Kingfisher.

BLue JaY.

Breast cinnamon; belly dull white.

BLUEBIRD

Underneath chestnut.

Barn Swallow.
PAGE General color a brilliant variegation of PAGE

97 black, white and orange.

93 Baltimore ORIOLE. 104

107

BLACKBURNIAN WARBLER.

165

General color pale crimson.

99

Back streaked with brown.

$$
\text { PURPl. FINCH. }
$$

133 General color gray.

Crown and throat black; cheeks white.

18

Chickadef.

199

General color red.

AMERICAN CROSSBILl. 111

Cardinal.

135

Summer TaNAger.

63

ol

Wings and tail black.

Scarlet Tanager.

General color redalish-brown, mucb barred and spotted.

WrENS (very small birds).

141
$191-194$ 
General color slate.

Belly white; tail with white outside feathers.

$$
\text { JuNCO. }
$$

Crown and tail black.

$$
\text { CATBIRD. }
$$

General color streaked with brown (or redtisb) and dull white (or yellowish).

ChIPPING SPARRow:

Field Sparrow.

Fox Sparrow.

PINE SISKIN.

Song Sparrow.

Chin white.

WHITE-THROATED SPARROW. I 1

Shoulders reddish : outer tail-feathers white.

Vesper Sparrow.

110

Shoulders yellow.

Grasshopper SPARROW.

125

117

131

115

120 paci General color zobite.

PAGE

SNOWFLAKE.

117

General color yellow.

127 Crown, wings and tail black.

AMERICAN GOLdFINCH.

Under-parts streaked with reddishbrown.

YELLOW WARBLER. 162

Tail with a white terminal band.

KINGBIRD.

Tail witb a yellow termmal band.

$$
\text { CEDAR Waxining. }
$$

Tbroat moy-red.

Back metallic-green.

123
Ruby-THROAT'D Humm'g Bird. $7^{8}$ 


\section{INDEX}

BeE-Martin, see Kingbird.

BlACKBIRD, Clow (or Common Crow), see I'urple Grackle

Marsh (or Swamp), see Red-winged Blackbird.

Red-winged, 30, 35, 40, 48, 90. PI. XXI.

Skunk, see Bobolink.

Bluebird, 31, 34, 35, 40, 50, 211.

Bobolink, 31, 37, 30, 48, 95. PI. XIX.

Bunting, Bay-winged, see Veşeer Sparrow.

Indigo, 31, 32, 37, 39, 4*, 1;0.

Snow, see Snowtlake.

Towhee, see Towhee.

Yellow-winged, see Crasshopper Sparrow.

Butcher-BIRD, see Northern Shrike.

Cardinal, $23,37,48,135$. Pl. XXXVI.

CAtBird, 31, 36, 39, 50, 187 . ['I. I.

Cedarbird, see Cedar Waxwing.

Chat, Yellow-breasted, 36, 38, 49, 181.

Chebec, see Least Flycatcher.

Cherrybird, see Cedar Waxwing.
CHEWINK, see Towhee.

Chickadee, 31, 34, 50, 199. PI. LX.

Chippy, see Chipping Sparrow.

Clape, see Flicker.

COWBIRD, 35, 30, 48, 97, 103. P1. XX.

Creeper (or Creeping Warbler), Black and White, see Black and White Wabler.

Crossbill, American (or Red), 3.4, 36, 4\$, 111. P. XXVI. Crow, American, 30, 34, 47, 81, 03. P'l, XVIII.

Cuckoo, Black-billed, 21, 23, 31, 37, 39, 40, 01. Pl. IV. Yellow-billed, 40, 02.

Finch, Grass, see Vesper Sparrow.

Pine, see Pine Siskin.

Purple, 34, 35, 40, 48, 100. Pl. XXV.

Firebird, see Baltimore Oriole.

Flicker, 31, 34, 35, 40, 40, 73. P'l. IX.

Flycatcher, Great Crested, 37, 30, 47, 83. I'I. XIll Least, 37, 39, 47, 80. [?]. XVI.

Yellow-bellied, 37, 38, 47, 87. PI. XV. 


\section{Index}

Goldfinch, American, 31, 32, 34, 48, 112 .

Grackle, Purple, 35, 40, 48, 107. PI. XXIV

Greentet, see Vireo.

Grosbeak, Cardinal, see Cardinal.

Rose-breasted, 30, 39, 48, 137. I1. XXXVII. HAIR-BIRD, see Chipping Sparrow.

Hangnest, see Baltimore Orjole.

HiGH-HOLE (or High-holder), see Flicker.

Hummingbird, Ruby-throated, 31, 37, 38, 47, 78 .

INDIGO-BIRD, see Indigo Bunting.

Jay, Blue, 31, 34, 47, 91. P1. XVII.

Junco, (or Slate-colored Junco), 48, 127. 11. XXX11.

Kingbird, 35, 38, 47, 81. PI. XII.

Kingfisher, Belted, 23, 31, 34, 35, 46, 63. PI. V.

KINGLET, Golden-crowned (or crested), 34, 36, 39, 50, 201. PI. LXI.

Ruby-crowned (or crested), 35, 36, 39, 50, 202.

LaRk, Horned, 34, 35, 30, 47, 93.

Linnet, Pine, see Pine Siskin.
LETTUCE-BIRD, see American Goldfinch.

Meadowlark, 31, 34, 35, 40, 48, 101. PI. XXIl.

MEAdOW-Wink, see Bobolink.

Myrtlebird, see Myrtle Warbler.

Night-JAR, see Whip-poor-will.

Nuthatch, White-breasted (or bellied), 34, 50, 197. PI. LIX,

Old Fieldlark, see Meadowlark.

OrIOLE, Baltimore, $31,36,38,48,104$.

Orchard, 37, 39, 48, 103 . P. XXIII.

OVEN-BIRD, 36, 40, 49, 183. PI. LIV.

OwL, Great Horned (or Hoot, or Cat), 34, 46, 57. Pl. II. Little Horned (or Mottled, or Red, or Screech), $34,40,59$.

Saw-whet (or Acadian), 34, 46, 55. Pl. 1.

Snowy, 34, 35, 46, 59. P. III.

PEABODY-BIRD, see White-throated Sparrow.

PEWEE, Water, see Phobe.

Wood, 37, 39, 47, 85.

P'ewit Flycatcher, see Phoebe. 


\section{Index}

PHEBE, 35, 40, 47, 85. Pl. XIV.

REEDBIRI), see Bobolink.

Redbird, Summer, see Sumner Tanager.

Redstart, American, 30, 30, 49, 183.

RICEBIRD, see Bobolink.

Robin, American, 30, 34, 35, 40, 50, 200. I'l. L.XIV.

Golden, see Baltimore Oriole.

Ground, see Towhee.

SAPSUCKer, Yellow-bellied, 23, 35, 40, 46, 69. PI. VII. SHrike, Northern, 23, 34, 35, 40, 40, 1.40. Pl. XLII.

Siskin, Pine, 34, 35, 39, 48, 15 . PI. XXVII.

SNOWBIRD, see Junco.

SNOWFLAKE, 34, 35, 40, 48, 117 . P1. XXVIII.

Sparrow, Clipping, 30, 40, 48, 125. PI. XXXI.

Field, 36, 40, 48, 117 .

Fox, 35, 31, 4', 4., 1:1. Pl. XXXIV.

Grasshopper (or Yellow-winged), 36, 39, 48, 123.

Song, 31, 33, 35, 40, 48, 129. P. XXXIII.

Vesper, 35, 40, 48, 119 . PI. XXIX.

White-throated, 34, 36, 37, 30, 48, 121. PI. XXX.
I SWAllow, Bank, 36, 38, 49, 145. PI. XL.

Barn, 31, 36, 38, 49, 141. P1. XXX1X.

Chimney, should be Chimney Swift q. v.

Swift, Chimney, 31, 30, 39, 47, 77. 11. Xl.

Tanager, Scarlet, 31, 37, 39, 48, 140.

Summer, 31, 48, 139. PI. XXXVIII.

ThISTLE-BIRD, see American Goldfinch.

Thrasher (or Thrush), Brown, 36, 30, 50, 189. Pl. LVI.

Thrush, Golden-crowned, see Oven-bird.

Hermit, 35, 37, 30, 50, 203, 205.

Red, see Brown Thrasher.

Wilson's (or Tawny), 30, $78,50,205,207$.

P. LXIII.

Wood (or Song), 30, 39, 50, 205. IH. LXII.

Tiтmouse, Black-capped, see Chickadee.

Towhee, 36, 40, 48, 133. PI. XXXV.

VEERY, see Wilson's Thrush.

VIREO, Blue-headed (or Solitary, 30, 30, 40, 155. P. XLIV.

Red-eyed, 37, 30, 40, 153. P1. XLIII.

White-eyed, 30, 39, 49, 157. PI. XLV. 


\section{Index}

ViREO, Yellow-throated, 36, 39, 49, 151.

WARBLER, Bay-breasted, 37, 39, 49, 173. PI. L.

Black and White, $36,39,49,159$. [1. XI.VI.

Black and Yellow, see Magnolia Warbler.

Blackburnian, 37, 38, 49, 105.

Black-poll, 37, 40, 49, 175. Pl. LI.

Black-throated Blue, 36, 30, 49, 157. I'1. XLVII.

Black-throated Green, 37, 40, 49, 177. 11. 1.11.

Blue Yellow-backed, see Myrtle Warbler.

Chestnut-sided, 36, 30, 40, 171. PI. XLIX.

Hooded, 37, 38, 49, 184 .

Magnolia, 37, 38, 40, 169. I'I. XLVIII.

Myrtle, 35, 38, 30, 49, 164.

Palm, 36, 39, 49, 179, PI. LIII.

Parula, 36, 39, 40, 161.

Worm-eating, 37, 39, 49, 160.

Yellow, 36, 37, 49, 162.

Yellow Red-poll, see Paln Warbler.

Yellow-rumped, see Myrtle Warbler.
Waxwing, Cedar, 31, 34, 49, 147. PI. XLI.

WHIP-POOR-WILL, 36, 38, 46, 75. PI. X.

WOODPECKER, Downy, 34, 46, 67.

Golden-winged, see Flicker.

Hairy, 34, 46, 67. PI. VI.

Pigeon, see Flicker.

Red-headed, 35, 30, to, 7r. PI. VIII.

Yellow-bellied, see Yellow-bellied Sapsucker.

WREN, Golden-crowned (or crested), see Golden-crowned

\section{Kinglet.}

House, 31, 30, 30, 50, 194.

Long-billed Marsh, 37, 30, 50, 193. PI. LVIII.

Ruby-crowned (or cresteil), see Ruby-crowned Kinglet.

Winter, 34, 36, 39, 50, 101. PI. LVII.

YELLOWBIRD, see American Goldfinch.

Summer, see Yellow-Warbler.

Yellowthroat, Maryland, 23, 37, 40, 49, 180.

YUCKep (or Yellowhammer), see Flicker. 


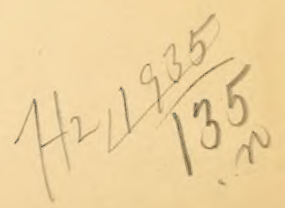


